\title{
CARACTERIZAÇÃO MORFOLÓGICA E MOLECULAR DE ÁCAROS PREDADORES DO GÊNERO Euseius (ACARI, PHYTOSEIIDAE)
}

\section{ALOYSÉIA CRISTINA DA SILVA NORONHA}

Tese apresentada à Escola Superior de Agricultura "Luiz de Queiroz", Universidade de São Paulo, para obtenção do título de Doutor em Ciências, Área de Concentração: Entomologia.

P I R A C I C A B A

Estado de São Paulo - Brasil

Janeiro -2002 


\title{
CARACTERIZAÇÃO MORFOLÓGICA E MOLECULAR DE ÁCAROS PREDADORES DO GÊNERO Euseius (ACARI, PHYTOSEIIDAE)
}

\section{ALOYSÉIA CRISTINA DA SILVA NORONHA}

Engenheiro Agrônomo

Orientador: Prof. Dr. GILBERTO JOSÉ DE MORAES

\begin{abstract}
Tese apresentada à Escola Superior de Agricultura "Luiz de Queiroz", Universidade de São Paulo, para obtenção do título de Doutor em Ciências, Área de Concentração: Entomologia.
\end{abstract}

P I R A C I C A B A

Estado de São Paulo - Brasil

Janeiro - 2002 
Dados Internacionais de Catalogação na Publicação (CIP)
DIVISÃO DE BIBLIOTECA E DOCUMENTAÇÃO - ESALQ/USP

Noronha, Aloyséia Cristina da Silva

Caracterização morfológica e molecular de ácaros predadores do gênero Euseius (Acari, Phyłoseiidae) / Aloyséia Cristina da Silva Noronha. - - Piracicaba, 2002.

$110 \mathrm{p}$.

Tese (doutorado) - Escola Superior de Agricultura Luiz de Queiroz, 2002.

Bibliografia.

1. Acari 2. Ácaro-fitófago 3. Controle biológico (Fitossanidade) 4.

Cruzamento animal 5. Ácaro-prepador 6. Seqüencia de DNA I. Título

CDD 632.6542

"Permitida a cópia total ou parcial deste documento, desde que citada a fonte - $\mathrm{O}$ autor" 


\section{AGRADECIMENTOS}

- Ao Dr. Gilberto José de Moraes, professor do Departamento de Entomologia, Fitopatologia e Zoologia Agrícola, da ESALQ/USP pela orientação e apoio na elaboração deste trabalho.

- Ao Dr. Luiz Lehmann Coutinho, professor do Departamento de Produção Animal ESALQ/USP, pelo apoio nos trabalhos de biologia molecular no Laboratório de Biotecnologia Animal do Departamento de Produção Animal.

- À Empresa Brasileira de Pesquisa Agropecuária (EMBRAPA) pela liberação para a realização do curso.

- Ao Dr. Angelo Pallini, professor da Universidade Federal de Viçosa (UFV) pelo envio da população de Euseius concordis (MG).

- À estagiária Ana Paula Santos (Embrapa - Semi-árido) pelo envio de populações de E. concordis $(\mathrm{PE})$ e E. citrifolius $(\mathrm{PE})$.

- Ao colega de curso Noeli Juarez Ferla pelo envio de populações de E. concordis (RS, MT) e E. citrifolius (RS).

- Ao pós-graduando Adilson Mota e demais estudantes e funcionários do Laboratório de Biotecnologia Animal do Departamento de Produção Animal, ESALQ/USP, pelo apoio e colaboração no trabalho de caracterização molecular. 
- Ao PRONEX pelo suporte financeiro na atividade de caracterização molecular.

- Ao Dr. Eliot W. Kitajima do Núcleo de Apoio à Pesquisa (ESALQ/USP) pela colaboração na realização deste trabalho.

- Ao Dr. Hans Breeuwer da Universidade de Amsterdam pelo colaboração nas análises para detecção de Wolbachia.

- Aos funcionários do Departamento de Entomologia, Fitopatologia e Zoologia Agrícola, e da Biblioteca da ESALQ/USP pela atenção dispensada.

- A todos os colegas do setor de Zoologia Agrícola pela amizade e convívio.

- Aos amigos Marilene, Míriam e Hílton pelo carinho e solidarieade.

- $\quad$ À todos aqueles que, de alguma forma, contribuíram para a realização deste trabalho. 
Dedico aos meus pais

Maria de Jesus (in memoriam) e Jarbas

e meus irmãos

Ginacélia, Herlander e Herdávio 


\section{SUMÁRIO}

Página

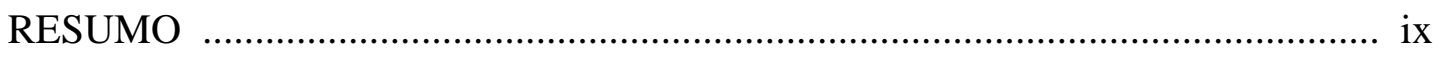

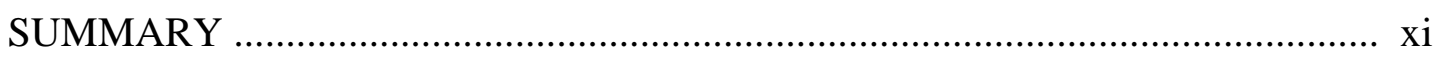

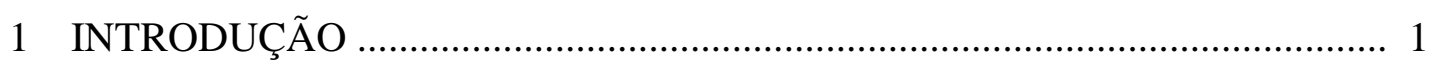

2 REVISÃO DE LITERATURA …........................................................ 3

2.1 Importância e aspectos biológicos de ácaros Phytoseiidae .............................. 3

2.2 Gênero Euseius Wainstein no Brasil ............................................................. 4

2.3 Distribuição e aspectos biológicos de Euseius citrifolius e E. concordis ........... 4

2.4 Incompatibilidade reprodutiva em Phytoseiidae ...................................... 6

2.5 Microrganismos simbiontes ….............................................................. 8

2.6 Técnicas de caracterização molecular …................................................... 9

2.6.1 Aplicação de técnicas moleculares no estudo de ácaros .......................... 11

3 VARIAÇÕES MORFOLÓGICAS INTRA E INTERPOPULACIONAIS

DE Euseius citrifolius E Euseius concordis (ACARI, PHYTOSEIIDAE) ............. 14

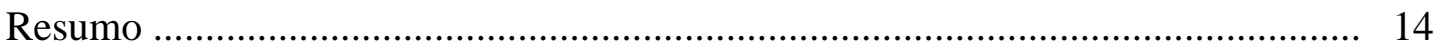

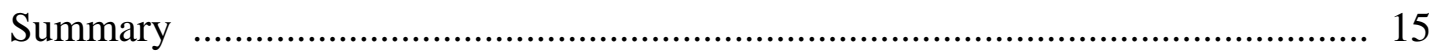

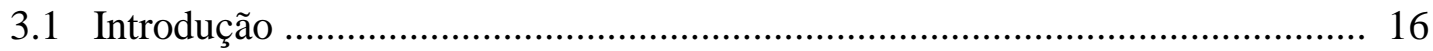

3.2 Material e Métodos ..................................................................................... 18

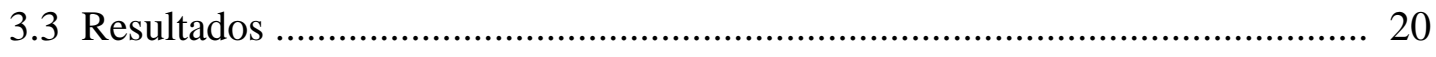

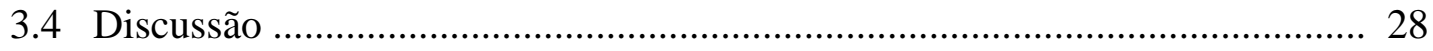


Página

3.5 Conclusões

4 COMPATIBILIDADE REPRODUTIVA ENTRE POPULAÇÕES IDENTIFICADAS COMO Euseius citrifolius (ACARI, PHYTOSEIIDAE) ......... 32

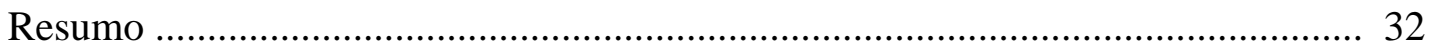

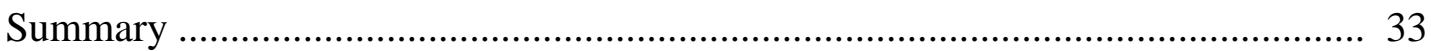

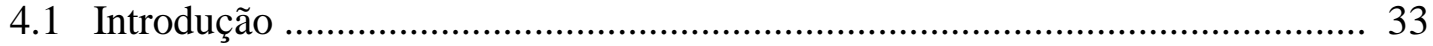

4.2 Material e Métodos ............................................................................... 35

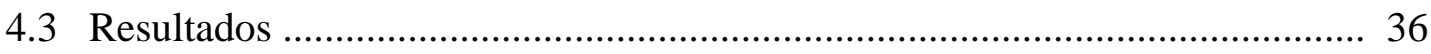

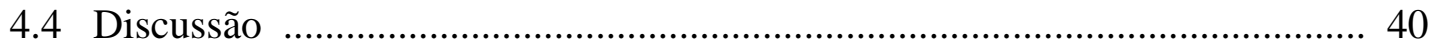

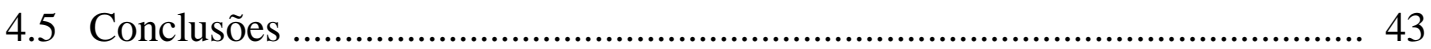

5 COMPATIBILIDADE REPRODUTIVA ENTRE POPULAÇÕES IDENTIFICADAS COMO Euseius concordis (ACARI, PHYTOSEIIDAE) ......... 44

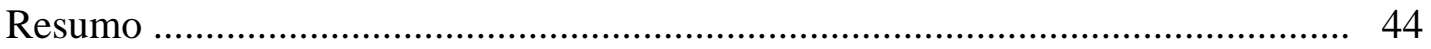

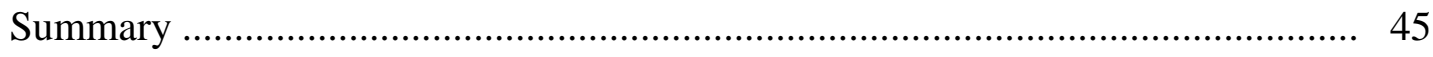

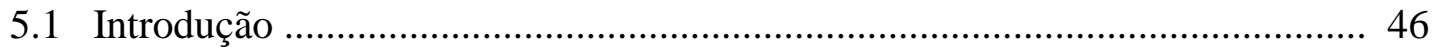

5.2 Material e Métodos .................................................................................. 47

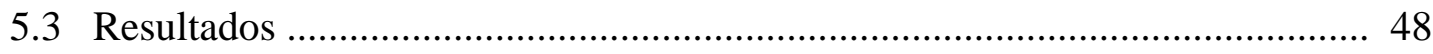

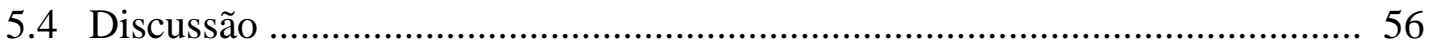

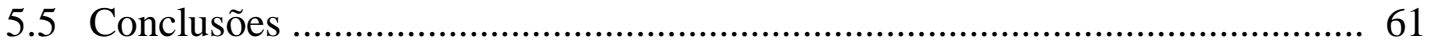

6 CARACTERIZAÇÃO MOLECULAR DE POPULAÇÕES IDENTIFICADAS COMO Euseius citrifolius E Euseius concordis (ACARI,

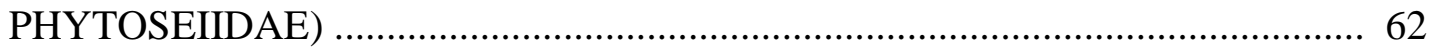

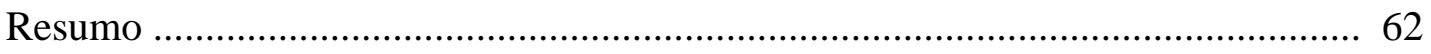

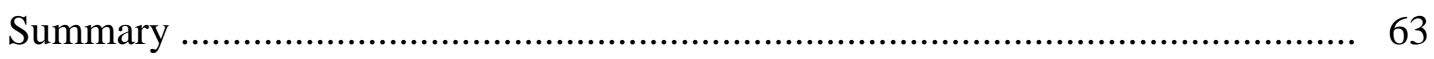

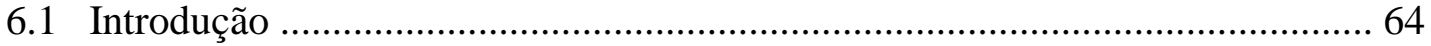

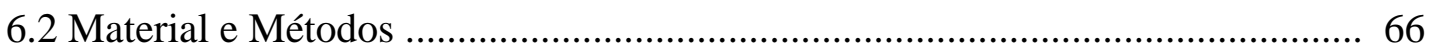


Página

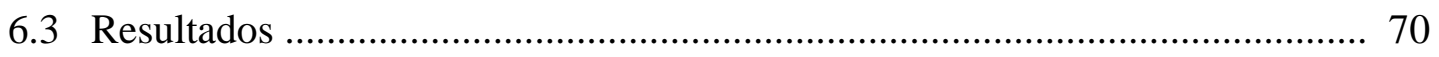

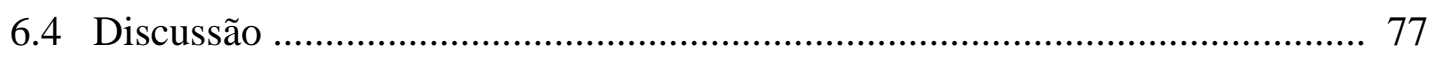

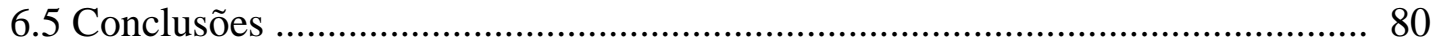

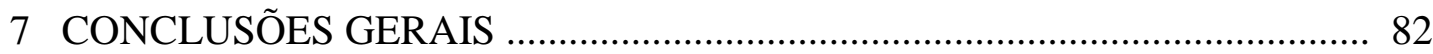

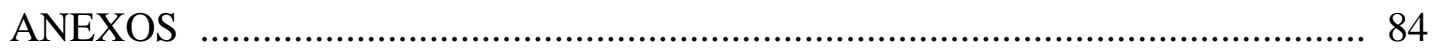

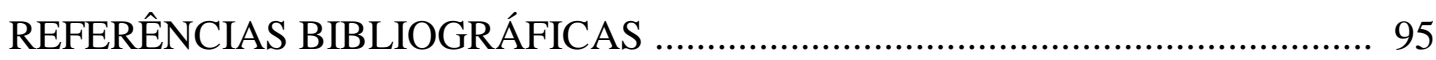




\title{
CARACTERIZAÇÃO MORFOLÓGICA E MOLECULAR DE ÁCAROS PREDADORES DO GÊNERO Euseius (ACARI, PHYTOSEIIDAE)
}

\author{
Autora: ALOYSÉIA CRISTINA DA SILVA NORONHA \\ Orientador: Prof. Dr. GILBERTO JOSÉ DE MORAES
}

\section{RESUMO}

Ácaros fitoseídeos são eficientes predadores de ácaros pragas em algumas culturas. A precisa identificação das espécies é o passo inicial na seleção de inimigos naturais em um projeto de controle biológico. Os ácaros são geralmente identificados com base nas características morfológicas, mas aspectos biológicos e ecológicos, e mais recentemente características moleculares vêm sendo usadas nesse processo. Populações dos fitoseídeos identificados como Euseius citrifolius Denmark \& Muma provenientes de Arroio do Meio-RS, Campinas-SP e Petrolina-PE, e Euseius concordis (Chant) procedentes de Arroio do Meio, Jaguariúna-SP, Petrolina, Pontes e Lacerda-MT e Viçosa-MG foram estudados em relação a morfologia, compatibilidade reprodutiva e características moleculares. A caracterização morfológica correspondeu as medições de estruturas de fêmeas e machos. A compatibilidade reprodutiva foi avaliada através de cruzamentos e retrocruzamentos homogâmicos e heterogâmicos. A caracterização molecular foi realizada com o seqüenciamento dos espaços internos transcritos (ITS1 e ITS2) do DNA ribossomal. Relações significativas foram observadas dentro de cada população entre o comprimento médio das setas e as respectivas amplitudes de variação. Ambos os sexos de E. citrifolius de Petrolina e E.concordis de Jaguariúna tiveram algumas setas mais curtas que as demais populações da mesma espécie; esta última 
diferiu marcadamente da população de Petrolina. A comparação das medições das estruturas de cada população e dos espécimes tipo de E. citrifolius e E. concordis confirmaram a identificação morfológica preliminar das populações ao nível de espécie. Medições de machos resultantes de cruzamentos heterogâmicos indicaram que essas espécies se reproduzem por pseudo-arrenotoquia. Incompatibilidade parcial foi observada nos cruzamentos heterogâmicos envolvendo fêmeas de E. citrifolius de Petrolina; descendentes produziram poucos ovos e inviáveis quando retrocruzadas com machos das populações parentais. Machos de Petrolina produziram descendentes viáveis quando cruzados com fêmeas de Arroio do Meio e Campinas. Não ocorreu oviposição nos cruzamentos e retrocruzamentos heterogâmicos envolvendo fêmeas de $E$. concordis de Petrolina. Nos cruzamentos heterogâmicos envolvendo machos de Petrolina a oviposição foi reduzida e somente machos (viáveis) foram produzidos. Cruzamentos de fêmeas de Pontes e Lacerda e machos de Jaguariúna e vice-versa produziram somente machos. Entretanto o fluxo gênico entre essas populações seria possível indiretamente, através de cruzamentos entre essas populações e a população de Arroio do Meio. Populações de Arroio do Meio, Jaguariúna, Pontes e Lacerda e Viçosa pertencem a mesma espécie. Maior variação entre as populações foi observada no espaçador ITS1. O seqüenciamento dos espaçadores ITS1 e ITS2 permitiu discriminar entre os grupos de populações identificadas como E. citrifolius de E. concordis. O seqüenciamento dos ITSs pode ser aplicado como uma ferramenta complementar na identificação de fitoseídeos. Apesar do fato de que alguns tipos de diferenças foram sempre observadas nesta tese entre a população de Petrolina identificada preliminarmente como E. concordis, não é conveniente descrever esta população como uma nova espécie, devido a dificuldade em separar indivíduos dessa população daqueles das populações identificadas como E.concordis. Para uma conclusão, é sugerido que outros estudos de cruzamentos sejam conduzidos com populações morfologicamente identificadas como E. concordis coletadas entre Petrolina e Viçosa, e que a caracterização molecular envolvendo o gene citocromo oxidase seja conduzida. 


\title{
MORPHOLOGIC AND MOLECULAR CHARACTERIZATION OF PREDATORY MITES OF THE GENUS Euseius (ACARI, PHYTOSEIIDAE)
}

\author{
Author: ALOYSÉIA CRISTINA DA SILVA NORONHA \\ Adviser: Prof. Dr. GILBERTO JOSÉ DE MORAES
}

\section{SUMMARY}

Phytoseiidae mites are efficient predators of pest mites on several crops. Precise identification is the initial step in the selection of natural enemies in a biological control project. Mites are usually identified by their morphology, but biological and ecological aspects and, more recently, molecular characteristics have also been used in this process. Populations of phytoseiid mites identified as Euseius citrifolius Denmark \& Muma from Arroio do Meio-RS, Campinas-SP and Petrolina-PE, and E. concordis (Chant) from Arroio do Meio, Jaguariúna-SP, Petrolina Pontes e Lacerda-MT and Viçosa-MG were studied in relation to morphology, reproductive compatibility and molecular characteristics. Morphological characterization corresponded to measurements of structures of females and males. Reproductive compatibility was evaluated by homogamic and heterogamic crosses and backcrosses. Molecular characterization was done by sequencing the internal transcribed spacers of the ribosomal DNA (ITS1 and ITS2). Significant relationships were observed within each population between mean setal lengths and the respective ranges. Both sexes of E. citrifolius from Petrolina and $E$. concordis from Jaguariúna had some setae shorter than other populations of the same species; the latter differed most markedly from the Petrolina population. A comparison of the measurements of structures for each population and type specimens of $E$. 
citrifolius and E. concordis confirmed the preliminary morphological identification of the populations at species level. Measurements of males resulting from heterogamic crosses indicated that both species reproduce by pseudo-arrhenotoky. Partial incompatibility was observed in heterogamic crosses involving females of E. citrifolius from Petrolina; progeny produced just few, unviable eggs when backcrossed with males of the parental populations. Males from Petrolina produced viable offspring when crossed with females from Arroio do Meio or Campinas. No eggs were produced in heterogamic crosses and backcrosses involving females of $E$. concordis from Petrolina. In heterogamic crosses involving males from Petrolina, oviposition was reduced and only (viable) males were produced. Crosses of females from Pontes e Lacerda and males from Jaguariúna and vice-versa produced only male progeny. However, gene flow between those population could be possible indirectly, through crosses between those populations and Arroio do Meio population. Populations from Arroio do Meio, Jaguariúna, Pontes e Lacerda and Viçosa belong to a same species. Most of the molecular variation between populations was observed in ITS1. The sequencing of ITS1 and ITS2 allowed the discrimination between the group of populations identified as $E$. citrifolius from that identified as E. concordis. With the information presently available, sequencing of ITSs can be applied as a complementary tool to identify phytoseiids. Despite the fact that some type of differences were always observed in this thesis between the Petrolina population preliminarily identified as E. concordis and the remaining populations, it is not convenient to describe such population as a new species presently, given the difficulty in separating individuals from that population from those of populations identified as E. concordis. For a conclusion, it is suggested that other crossing studies be conducted with populations morphologically identifiable as $E$. concordis collected between Petrolina and Viçosa, and that the characterization of the cytochrome oxidase gene be conducted. 


\section{INTRODUÇÃO}

Ácaros da família Phytoseiidae são eficientes inimigos naturais de ácaros pragas de vários cultivos. Espécies nativas ou exógenas desta família têm sido empregadas no controle biológico de ácaros fitófagos em condições de campo e casa-devegetação.

No processo de seleção de populações de fitoseídeos mais eficazes para o uso em programas de controle biológico, um dos pontos de partida é a identificação das espécies correspondentes. Em muitos casos, somente as evidências morfológicas não são suficientes para a identificação das espécies, pois as variações intra-específicas não são conhecidas ou algumas vezes não permitem uma precisa distinção entre espécies muito parecidas. Nestes casos, é conveniente a utilização de outros tipos de evidências. Um dos exemplos nesse aspecto refere-se aos resultados recentes de estudos de cruzamentos realizados por Furtado (1997), sugerindo que as pequenas diferenças morfológicas entre populações de Euseius concordis (Chant) procedentes de Jaguariúna-SP e Petrolina-PE, coletadas respectivamente em folhas de Manihot esculenta Crantz e Terminalia catappa L., poderiam na realidade corresponder à existência de duas espécies muito próximas, mas distintas do ponto de vista biológico. A conclusão definitiva nesse caso exigiria estudos adicionais envolvendo cruzamentos entre aquelas populações e populações geograficamente intermediárias.

A caracterização molecular de grupos desta família também poderia auxiliar na taxonomia desses agentes de controle biológico. No estudo taxonômico de fitoseídeos, a aplicação da caracterização molecular, em complemento aos estudos morfológicos e de cruzamentos, poderia talvez permitir a elucidação de aspectos importantes relacionados 
à filogenia das espécies estudadas, e contribuir no processo de seleção de biótipos para o emprego em programas de controle biológico.

Euseius citrifolius Denmark \& Muma e E. concordis são fitoseídeos comumente encontrados em diferentes espécies de plantas, de acordo com a região. $E$. concordis é uma das espécies predominantes em plantas de mandioca nas regiões sudeste e centro-oeste, não ocorrendo comumente em citros. Entretanto, na região nordeste esta espécie é predominante em citros e raramente encontrada mandioca. Esta diferença em relação às plantas hospedeiras poderia corresponder a existência de populações morfologicamente semelhantes ou idênticas mas reprodutivamente isoladas.

Este trabalho teve por objetivo estudar a compatibilidade reprodutiva e realizar a caracterização morfológica e a molecular de populações identificadas como $E$. citrifolius e E. concordis, provenientes de regiões distantes entre si, para avaliar a possibilidade de uso da caracterização molecular como uma ferramenta auxiliar para a identificação desses ácaros. Além disso, possibilitar o treinamento e capacitação em estudos moleculares de predadores potencialmente úteis no controle de ácaros fitófagos. 


\section{REVISÃO DE LITERATURA}

\subsection{Importância e aspectos biológicos de ácaros Phytoseiidae}

A família de ácaros predadores Phytoseiidae destaca-se como um grupo de importância em várias culturas (McMurtry et al., 1970; McMurtry, 1982), com mais de mil e setecentas espécies descritas em todo o mundo (Kostiainen \& Hoy, 1996).

Os fitoseídeos têm sido empregados no controle biológico de ácaros fitófagos em plantas ornamentais, hortaliças, cultivos em casa-de-vegetação (hortaliças e ornamentais) e de campo (citros, milho, mandioca e morango) (Hamlen, 1978; Houten et al., 1995; Hoy \& Glenister, 1991; International Institute of Tropical Agriculture, 1995; McMurtry et al., 1978; Peña \& Osborne, 1996; Pickett \& Gilstrap, 1986 e Rasmy \& Ellaithy, 1988). Uma das características mais importantes dos fitoseídeos é o baixo consumo alimentar de cada indivíduo de uma população, o que os torna mais eficientes que predadores de outros grupos favorecendo o estabelecimento e permanência em campo mesmo nos períodos de densidade populacional relativamente baixa da presa (Moraes, 1991). Nem sempre os ácaros fitófagos são o alimento preferido de fitoseídeos (McMurtry et al., 1970). Algumas espécies alimentam-se também de pólen, fungos, exsudato, insetos e secreções adocicadas (Bakker, 1993; Fouly et al., 1995; Grout \& Richards, 1992; Meyerdirk \& Coudriet, 1985; Noronha \& Mesa, 1990; Oduor, 1988 e Yue \& Tsai, 1996). Fitoseídeos do gênero Euseius preferem certos tipos de pólen como alimento (McMurtry \& Croft, 1997).

Diversos trabalhos têm sido realizados sobre a caracterização morfológica e distribuição geográfica de fitoseídeos no Brasil (Denmark \& Muma, 1973; El-Banhawy, 
1975, 1976, 1978 e 1984; Gondim Junior \& Moraes, 2001; Lofego, 1998; Moraes \& McMurtry, 1983; Moraes et al., 1986 e 1997, e Zacarias, 2001).

\subsection{Gênero Euseius Wainstein no Brasil}

As espécies pertencentes ao gênero Euseius constatadas no Brasil e citadas por Lofego (1998) e Moraes et al. (1986) são E. alatus DeLeon, E. brazilli El-Banhwy, E. citrifolius, E. concordis, E. hibisci (Chant), E. ho (DeLeon), E. inouei (Ehara \& Moraes), E. plaudus Denmark \& Muma, E. sakagamii (Ehara), E. sibelius (DeLeon), E. unisetus Moraes \& McMurtry e E. vivax (Chant \& Baker). Acredita-se que E. hibisci não ocorra no Brasil, e que sua constatação possa representar uma identificação incorreta ${ }^{1}$. Dentre estas espécies, E. citrifolius e E. concordis têm sido estudadas quanto às suas características morfológicas, biológicas e quanto à compatibilidade reprodutiva de algumas populações (Furtado, 1997; Lofego, 1998; Moraes \& McMurtry, 1981; Moraes \& Lima, 1983; Moreira, 1993). Estas espécies são comumente encontradas em diferentes regiões e em várias plantas hospedeiras (Feres, 2000; Furtado, 1997; Moraes et al., 1986; Pallini Filho et al., 1992 e Sato et al., 1994).

\subsection{Distribuição e aspectos biológicos de Euseius citrifolius e E. concordis}

Euseius citrifolius foi descrito a partir de espécimes coletados em Citrus sp., em Assunção, Paraguai (Denmark \& Muma, 1970), sendo também relatado na Colômbia, Nicarágua e Peru (McMurtry \& Moraes, 1989 e Moraes et al., 1991). No Brasil, a ocorrência dessa espécie foi verificada no nordeste (Bahia, Pernambuco, Ceará e Paraíba), sudeste (Minas Gerais e São Paulo) e sul (Rio Grande do Sul), estando presente em cultivos de mandioca, cafeeiro, seringueira e citros (Feres, 2000; Ferla \& Moraes, 1998; Furtado, 1997; Moraes et al., 1986; Moreira, 1993 e Pallini Filho et al., 1992).

\footnotetext{
${ }^{1}$ MORAES, G.J. de. Escola Superior de Agricultura "Luiz de Queiroz". ESALQ/USP. Comunicação pessoal, 2001.
} 
Um estudo sobre a biologia de E. citrifolius foi conduzido por Moraes \& McMurtry (1981), para avaliar o desenvolvimento, comportamento, oviposição e longevidade em diferentes temperaturas, umidades e tipos de alimentos. Aqueles autores verificaram oviposição média diária de 0,8 a 2,5 ovos por fêmea, e que os pólens de Pyrus kawakamii Hayata, Malephora crocea (Jacq.) e abacate foram os melhores alimentos para E. citrifolius. Moreira (1993) avaliou o ciclo de vida, longevidade e aspectos reprodutivos quando esse ácaro foi alimentado com Brevipalpus phoenicis (Geijskes) e pólens de mamona (Ricinus communis L.) e de taboa (Typha angustifolia L.), verificando a oviposição média diária de 1,5 ovos por fêmea e concluindo que o pólen de taboa foi o melhor alimento para a reprodução de E. citrifolius. Furtado (1997) mostrou que E. citrifolius apresenta melhor desempenho quanto à sobrevivência e reprodução quando alimentado com pólens de taboa e de mamona, em relação à alimentação com os ácaros Mononychellus tanajoa (Bondar), Tetranychus urticae Koch e Phyllocoptruta oleivora (Ashmead). Esta autora verificou oviposição média diária de 0,9 a 1,7 ovos por fêmea.

Euseius concordis foi descrito a partir de espécimes coletados em Citrus sp., em Concórdia, Entre Rios, Argentina (Chant, 1959). Essa espécie também foi registrada no Brasil, Colômbia, Costa Rica, El Salvador, Guatemala, Nicarágua, Portugal e Trinidad-Tobago (Moraes et al., 1986). McMurtry (1977) sugere que o registo de $E$. concordis em Portugal possa não ser correto. No Brasil, foi registrado no nordeste (Bahia, Ceará, Paraíba e Pernambuco), sudeste (Minas Gerais e São Paulo) e sul (Rio Grande do Sul), sendo encontrada em cultivos de cafeeiro, citros, macieira, seringueira e mandioca, e em invasoras (Feres, 2000; Ferla \& Moraes 1998; Furtado, 1997; Moraes et al., 1986 e 1993, Pallini Filho et al., 1992). E. concordis é uma das espécies predominantes em plantas de mandioca nas regiões sudeste e centro-oeste, não ocorrendo comumente em citros. Entretanto, na região nordeste esta espécie é predominante em citros e raramente encontrada mandioca ${ }^{2}$.

\footnotetext{
${ }^{2}$ MORAES, G.J. de. Escola Superior de Agricultura "Luiz de Queiroz". ESALQ/USP. Comunicação pessoal, 2001.
} 
Aspectos biológicos de E. concordis foram estudados em laboratório por Moraes \& Lima (1983). Estes autores verificaram ciclos biológicos e índices de oviposição similares quando o predador foi alimentado com Aculops lycopersici (Massee) ou pólen de mamona, com oviposição média diária de 1,7 e 2,1 ovos por fêmea, respectivamente. Mesa et al. (1990) concluíram que quando alimentado com $M$. tanajoa e T. urticae, E. concordis necessitou de um suplemento alimentar, como pólen de mamona, para melhor sobrevivência da colônia. O pólen de taboa foi utilizado por Furtado (1997) para o estabelecimento de colônias dessa espécie em laboratório.

Tem sido demonstrado até o momento que 3 espécies de fitoseídeos a saber, Neoseiulus bibens (Blommers), Phytoseiulus persimilis Athias-Henriot e Galendromus occidentalis (Nesbitt), se reproduzem através de um processo conhecido como pseudoarrenotoquia ou parahaploidia (Schulten, 1985). Esse processo envolve a cópula com a fertilização subseqüente de todos os óvulos e produção de descendência constituída por machos e fêmeas. Entretanto, as fêmeas dos ácaros que apresentam este processo são diplóides e os machos, haplóides, em decorrência da eliminação de um conjunto de cromossomos durante o desenvolvimento dos embriões que dão origem a machos (Schulten, 1985). Tem-se demonstrado que o conjunto de cromossomos eliminado é de origem paterna (Sabelis \& Nagelkerke, 1988). A avaliação do tamanho de endospermatóforos e da morfologia de machos provenientes de cruzamentos e retrocruzamentos heterogâmicos entre populações de E. concordis procedentes de Jaguariúna-SP e Petrolina-PE indicou a ocorrência de pseudo-arrenotoquia nessa espécie (Furtado, 1997).

\subsection{Incompatibilidade reprodutiva em Phytoseiidae}

A taxonomia é a teoria e a prática de classificar organismos, cabendo também ao taxonomista estudar o relacionamento entre espécies e identificar diferenças biológicas entre populações de uma mesma espécie que indiquem a ocorrência de 
biótipos (Moraes, 1987). Do ponto de vista biológico, espécies são agrupamentos de populações naturais intercruzantes que são reprodutivamente isolados de outros grupos de populações pertencentes a outras espécies (Mayr, 1977).

Alguns estudos de reprodução de fitoseídeos têm sido realizados para elucidar a incompatibilidade reprodutiva entre espécies próximas e a compatibilidade reprodutiva entre populações identificadas como pertencentes a uma mesma espécie. Colônias de $G$. occidentalis da Califórnia, Washington e Utah, Estados Unidos da América, apresentaram incompatibilidade reprodutiva resultando na produção de ovos inviáveis, redução na taxa de oviposição em alguns retrocruzamentos e aumento na mortalidade na fase imatura (Croft, 1970). Incompatibilidade reprodutiva unidirecional foi verificada entre uma população de $G$. occidentalis de pomar de macieira e uma colônia de laboratório derivada daquela população mas submetida a uma pressão de seleção para resistência a permetrina durante dois anos. A incompatibilidade foi verificada com produção de poucos ovos, muitos dos quais inviáveis (Hoy \& Knop, 1981).

Através de cruzamentos envolvendo populações de Euseius de abacate e citros, Congdon \& McMurtry (1985) concluíram que duas espécies próximas ocorriam na Califórnia, E. hibisci (Chant) e E. tularensis Congdon. Incompatibilidade reprodutiva foi também verificada entre populações identificadas como $P$. persimilis, $P$. macropilis (Banks), P. longipes Evans e P. fragarie Denmark \& Schicha (Takahashi \& Chant, 1993). O mecanismo pré-cópula foi citado pelos autores como responsável pela incompatibilidade.

Resultados de cruzamentos e retrocruzamentos entre populações identificadas como E. concordis procedentes de Jaguariúna-SP e Petrolina-PE levaram Furtado (1997) a sugerir completo isolamento reprodutivo, considerando que aparentemente não ocorreu troca gênica entre as populações apesar do acasalamento entre fêmeas de Jaguariúna e machos de Petrolina ter sido suficiente para promover a oviposição. Os resultados indicaram que as populações poderiam corresponder à existência de espécies morfologicamente parecidas mas biologicamente distintas, sendo necessária a realização de estudos semelhantes envolvendo também populações geograficamente intermediárias para uma conclusão definitiva. Outros estudos de cruzamentos de fitoseídeos 
envolveram as espécies Amblyseius pontentillae (Garman) (McMurtry et al., 1976), G. occidentalis (Hoying \& Croft, 1977), Euseius finlandicus (Oudemans) (McMurtry, 1980), Euseius. quetzali McMurtry (Congdon \& McMurtry, 1986) e Euseius mesembrinus (Dean) (Abou-Setta et al., 1991).

Diversos são os fatores que podem levar à incompatibilidade reprodutiva entre duas populações. Mayr (1977) subdividiu os mecanismos de isolamento reprodutivo em duas classes, mecanismos pré-copulatórios e pós-copulatórios. Os mecanismos précopulatórios incluem o isolamento de habitat (casais potenciais não se encontram), o isolamento etológico (casais potenciais se encontram mas não se cruzam) e o isolamento mecânico (tentativa de cópula sem transferência de esperma). Os mecanismos póscopulatórios incluem a mortalidade gamética (ocorre transferência de esperma, sem fertilização do óvulo), a mortalidade do zigoto (o óvulo é fertilizado mas o zigoto morre), a inviabilidade do híbrido (o zigoto produz um híbrido F1 de reduzida viabilidade) e a esterilidade do híbrido (o zigoto do híbrido F1 é viável mas parcialmente ou totalmente estéril, ou produz F2 deficiente).

A incompatibilidade reprodutiva pode também ter causas exógenas, e estar relacionada com a presença de microrganismos simbiontes (Werren, 1997) que podem estar presentes no sistema reprodutivo causando efeitos em seus hospedeiros (Geest et al., 2000).

\subsection{Microrganismos simbiontes}

Em alguns organismos, a incompatibilidade reprodutiva relaciona-se à presença de microrganismos simbiontes, como as bactérias do gênero Wolbachia (Bordenstein et al., 2001; Breeuwer \& Werren, 1990; Hoy \& Cave, 1988; O’Neill \& Karr, 1990). Aspectos da biologia de Wolbachia, com relação à distribuição e filogenia, mecanismos de ação, evolução e implicações no controle biológico foram abordados em uma revisão feita por Werren (1997). Wolbachia é uma bactéria intracelular localizada nos tecidos reprodutivos de artrópodos, induzindo a incompatibilidade citoplasmática que pode se apresentar de duas formas, unidirecional ou bidirecional. A incompatibilidade 
unidirecional ocorre quando o esperma de machos infectados com Wolbachia fertiliza fêmeas não infectadas, neste caso, o cruzamento recíproco (machos não infectados e fêmeas infectadas) é compatível. A incompatibilidade bidirecional ocorre quando machos e fêmeas apresentam diferentes populações mutuamente incompatíveis de Wolbachia. Essa bactéria tem sido reportada em insetos, isópodos, ácaros e recentemente, em um nematóide (Werren, 1997).

Alguns estudos reportam a ocorrência de mortalidade do embrião e razão sexual em favor de machos descendentes quando do cruzamentos entre populações dos ácaros fitófagos Tetranychus neocaledonicus André, Amphitetranychus quercivorus (Ehara \& Goth), Panonychus ulmi (Koch) e P. mori Yokoyama, e do fitoseídeo G. occidentalis, sugerindo a possibilidade de incompatibilidade devido à ocorrência de microrganismos (Breeuwer \& Jacobs, 1996; Hoy \& Cave, 1988). A detecção e a identificação de Wolbachia pode ser feita através da técnica de reação em cadeia da polimerase, conhecida como PCR (do inglês 'Polymerase Chain Reaction"). A presença dessa bactéria foi constatada através dessa técnica em criações de laboratório de $P$. persimilis, G. occidentalis, Neoseiulus barkeri Hughes e N. bibens (Breeuwer \& Jacobs, 1996; Johanowicz \& Hoy, 1996).

É possível que a incompatibilidade reprodutiva entre populações e colônias de fitoseídeos, citada em vários estudos, seja consequiência de diferenças genéticas entre seus simbiontes (Hoy, 1985).

\subsection{Técnicas de caracterização molecular}

Marcadores isoenzimáticos fornecem informação genética para diversas aplicações, principalmente em estudos de genética de populações, de genética florestal e no melhoramento de plantas, para a caracterização de variedades e avaliação de germoplasma. Empresas têm utilizado isoenzimas para identificar a pureza genética de sementes comerciais (Ferreira \& Grattapaglia, 1998; Pinto et al., 2001). Qualquer enzima revelada pela técnica de eletroforese é denominada isoenzima (Berlocher, 1984). A detecção de isoenzimas abrange basicamente a extração de proteínas de um 
organismo, a separação destas proteínas através de eletroforese e a coloração histoquímica do gel (Ferreira \& Grattapaglia, 1998; Pinto et al., 2001).

Com o advento das técnicas modernas de biologia molecular surgiram diversos métodos de detecção de polimorfismo genético ao nível de DNA. A técnica empregada para estudar o polimorfismo no comprimento de fragmentos de restrição é conhecida como RFLP (do inglês "Restriction Fragment Length Polymorphism”). Esta técnica tem por base o fato de que o DNA de um organismo poder ser fragmentado através do uso de enzimas de restrição. A enzima de restrição reconhece uma seqüência específica de bases do DNA (4 a 8 nucleotídeos), cortando a molécula de DNA no sítio de reconhecimento ou próximo dele. O polimorfismo se verifica pela presença ou ausência de sequiências específicas de bases, que irão alterar o tamanho de fragmentos entre diferentes indivíduos (Ferreira \& Grattapaglia, 1998; Lanza et al., 2000).

A facilidade, versatilidade e sensibilidade da técnica da reação em cadeia da polimerase (PCR) torna-a particularmente poderosa para estudos genético-moleculares, através da síntese enzimática in vitro de milhões de cópias de um segmento específico de DNA na presença da enzima DNA polimerase que é catalizadora da reação (Alberts et al., 1998; Ferreira \& Grattapaglia, 1998). Essa técnica é relativamente simples e se baseia na combinação de amostras de DNA com um par de oligonucleotídeos usados como indicadores ("primers"), 4 nucleotídeos que compõem a cadeia do DNA, e a enzima DNA polimerase em uma solução tampão (Hoy, 1994). A técnica de PCR tem favorecido diagnósticos de doenças infecciosas e genéticas, tem sido aplicada na medicina legal além de possibilitar o estudo do DNA de plantas, animais fósseis e outros organismos (Farah, 1997).

O grande avanço na área de marcadores moleculares baseados em PCR ocorreu em 1990, com a utilização de "primers" mais curtos (um primer de 10 nucleotídeos) e de sequiência arbitrária para dirigir a reação de amplificação de um fragmento de DNA, eliminando a necessidade do conhecimento prévio da seqüência do DNA. Essa técnica que foi denominada de polimorfismo de DNA amplificado ao acaso, conhecida como RAPD (do inglês "Random Amplified Polimorphic DNA”), é basicamente uma variação do protocolo de PCR (Ferreira \& Grattapaglia, 1998). 
Microssatélites são definidos como pequenos fragmentos de DNA constituídos por pequenas seqüências de 1 a 4 nucleotídeos de comprimento, repetidas em um dado ponto do genoma. Eles vêm sendo estudados desde o início dos anos 80, no estudo de genética de populações por serem freqüentes e distribuídos ao acaso, permitindo um conhecimento mais amplo de qualquer genoma eucarioto (organismos cujas células apresentam núcleo distinto, separado do citoplasma pela membrana nuclear). As regiões apresentando sequiências repetidas são amplificadas individualmente através de PCR, com a utilização de "primers" específicos complementares às sequiências que flanqueiam o microssatélite (Ferreira \& Grattapaglia, 1998; Lanza et al., 2000).

\subsubsection{Aplicação de técnicas moleculares no estudo de ácaros}

Técnicas de eletroforese, que permitem a separação discreta de variantes de enzimas, têm ajudado a esclarecer relações entre populações em uma variedade de organismos, incluindo ácaros (Bakker, 1993; Jones \& Morse, 1995; Osakabe \& Komazaki, 1996; Tsagkarakou et al., 1996, 1997 e 1998; Ward et al., 1982).

As aplicações de métodos moleculares e o impacto dessa inovação tecnológica na acarologia são discutidas por Navajas \& Fenton (2000). Estes autores citaram que a biologia molecular tem sido empregada no estudo da diversidade genética ao nível intra e interespecífico para ácaros de interesse econômico na agricultura, pertencentes às famílias Tetranychidae, Eriophyidae e Phytoseiidae, e para ácaros de interesse médico veterinário, da família Ixodidae.

Um estudo da diversidade intra-específica de Mononychellus progressivus

Doreste em populações da África e da América do Sul, baseado em testes de cruzamentos e na comparação das seqüências de DNA ribossomal e mitocondrial, foi realizado por Navajas et al. (1994). Foram comparadas as sequiências de nucleotídeos do gene citocromo oxidase subunidade I (COI), do DNA mitocondrial (DNAmt), e do espaçador interno transcrito subunidade 2 (ITS2) do DNA ribossomal (DNAr). Os autores verificaram uma incompatibilidade reprodutiva parcial e variação interepopulacional, sugerindo a ocorrência de incompatibilidade genética com base nas diferenças entre as seqüências de DNA. Estudo semelhante, com o seqüenciamento do 
gene COI de 20 espécies de ácaros Tetranychidae e Tenuipalpidae resultaram em uma classificação destes organismos compatível com aquela baseada em caracteres morfológicos (Navajas et al., 1996). Outros estudos sobre relações evolutivas de espécies de tetraniquídeos e comparação genética entre espécies crípticas baseados nas seqüências do gene COI e do espaçador ITS2 foram realizados por Navajas et al. (1997) e Gotoh et al. (1998). As sequiências da região ITS2 também têm sido usadas na identificação de espécies de Eriophyidae e Ixodidae (Fenton et al., 1995; Wesson et al., 1993).

Um trabalho preliminar com aplicação de técnicas moleculares em fitoseídeos foi realizado recentemente por Navajas et al. (1999), com o estudo do nível de variação na seqüência da região ribossomal ITS (subunidades 1 e 2) de Neoseiulus californicus (McGregor), N. fallacis (Garman), E. concordis, G. occidentalis, Typhlodromus pyri Scheuten e $P$. persimilis. Os autores verificaram maior variação na seqüência de nucleotídeos na região do espaçador ITS1 que na região do espaçador ITS2, sugerindo que os espaçadores ITS possam ser usados para a separação de espécies de fitoseídeos.

A técnica de RAPD foi usada por Edwards et al. (1997) na comparação de três espécies de fitoseídeos morfologicamente similares, Typhlodromalus limonicus (Garman \& McGregor), Typhlodromalus manihoti (Moraes) e Typhlodromalus tenuiscutus (McMurtry \& Moraes). Os autores concluíram que essa técnica pode ser usada na distinção de outras espécies crípticas, ressaltando a necessidade de confirmação dos resultados através de cruzamentos. Uma das desvantagens mencionadas por aqueles autores foi de que essa técnica não pode ser usada em teste com ácaros individuais, como no caso do estudo da variabilidade intra-específica, devido à pequena quantidade de DNA obtida. Entretanto, Hance et al. (1998) aplicaram essa técnica para comparar populações de Tetranychus sp. com extração de DNA de fêmeas adultas individuais. Yli-Mattila et al. (2000) utilizaram três métodos de extração de DNA de um único ácaro no emprego dessa técnica, concluindo que a extração com o uso de resina Chelex 100®, além de simples, forneceu melhores resultados no estudo das variações intra-específica e interespecífica em populações de E. finlandicus. 
Em estudo preliminar para avaliar a presença de seqüências de microssatélites, Navajas et al. (1998a) mostraram que estes são raros em 2 espécies de ácaros de famílias diferentes, T. urticae (Tetranychidae) e N. fallacis (Phytoseiidae). Os estudos na busca de microssatélites em ácaros têm continuado, tendo sido recentemente registrada a ocorrência de microssatélites no ácaro parasito de abelhas, Varroa jacobsoni Oudemans (Evans, 2000; Navajas \& Fenton, 2000). 


\section{VARIAÇÕES MORFOLÓGICAS INTRA E INTERPOPULACIONAIS DE Euseius citrifolius E Euseius concordis (ACARI, PHYTOSEIIDAE)}

\section{RESUMO}

O reconhecimento de variações morfológicas entre e dentro de populações de fitoseídeos é importante para permitir a precisa identificação das espécies. Euseius citrifolius Denmark \& Muma e Euseius concordis (Chant) são fitoseídeos muito comumente encontrados em diferentes culturas em várias regiões do Brasil e outros países da América do Sul. A caracterização morfológica de populações preliminarmente identificadas como E. citrifolius e E. concordis foi realizada através do exame de 10 exemplares fêmeas e 10 machos adultos de cada população, e de 2 a 10 exemplares adultos resultantes de cruzamentos entre ácaros daquelas populações. Os substratos e locais de coleta de cada população foram: E. citrifolius: Bauhinia sp. em Arroio do Meio-RS, Coffea arabica L. em Campinas-SP e Terminalia catappa L. em PetrolinaPE; E. concordis: Passiflora edulis Sims. f. flavicarpa Deg. em Arroio do Meio, Manihot esculenta (Crantz) em Jaguariúna-SP, Hevea brasiliensis Muell. Arg. em Pontes e Lacerda-MT, T. catappa em Petrolina e C. arabica em Viçosa-MG. A comparação das medições das diferentes estruturas dos indivíduos de cada população e as medições dos espécimes tipo de E. citrifolius e E. concordis confirmaram a identificação preliminar das populações. Foi verificada uma relação significativa entre as dimensões médias das setas e os valores das amplitudes de variação dentro de cada população. Fêmeas e machos de E. citrifolius de Petrolina e de E. concordis de Jaguariúna, apresentaram algumas setas com dimensões menores que as setas correspondentes nas outras populações. Medições de machos resultantes de 
cruzamentos heterogâmicos indicaram que E. citrifolius e E. concordis se reproduzem por pseudo-arrenotoquia.

\section{MORPHOLOGIC VARIATION WITHIN AND BETWEEN POPULATIONS OF Euseius citrifolius AND Euseius concordis (ACARI, PHYTOSEIIDAE)}

\section{SUMMARY}

The determination of morphologic variability within and between populations of phytoseiid mites is important for the precise species identification. Euseius citrifolius Denmark \& Muma and Euseius concordis (Chant) are phytoseiids commonly found on different crops in Brazil and other South American countries. The morphologic characterization of populations preliminarily identified as E. citrifolius and E. concordis was done through examination of 10 adult females and 10 adult males of each population and of 2 to 10 adult females and males resulting from crosses between those populations. The plant substrate and collection site of each population were: $E$. citrifolius: Bauhinia sp. in Arroio do Meio-RS, Coffea arabica L. in Campinas-SP and Terminalia catappa L. in Petrolina-PE; E. concordis: Passiflora edulis Sims. f. flavicarpa Deg. in Arroio do Meio, Manihot esculenta (Crantz) in Jaguariúna-SP, Hevea brasiliensis Muell. Arg. in Pontes e Lacerda-MT, T. catappa in Petrolina and $C$. arabica in Viçosa-MG. A comparison of the measurements of different structures of individuals of each population and of type specimens of E. citrifolius and E. concordis confirmed the preliminary identification of the populations. Significant relationships were observed between mean setal lengths and the respective ranges within each population. Females and males of E. citrifolius from Petrolina and E. concordis from Jaguariúna had some of the setae generally shorter than those of other populations of the same species. Measurements of males resulting from heterogamic crosses indicated that E. citrifolius and E. concordis reproduce by pseudo-arrhenotoky. 


\subsection{Introdução}

A identificação de ácaros da família Phytoseiidae é normalmente realizada pela avaliação de suas características morfológicas. Entretanto, variações nos caracteres morfológicos entre indivíduos ou populações de uma espécie de organismo são sempre esperadas. O que comumente não se conhece, entretanto, é a amplitude esperada de variação de cada caráter considerado.

Poucos estudos no sentido de se conhecer as variações morfológicas de ácaros fitoseídeos têm sido conduzidos. Variações morfológicas entre 8 populações de Galendromus longipilus (Nesbitt) e 12 populações de Galendromus occidentalis (Nesbitt) provenientes de diferentes regiões dos Estados Unidos da América foram observadas por Hoying \& Croft (1977). Os autores verificaram que o comprimento do peritrema e o comprimento do escudo dorsal foram os caracteres morfológicos que permitiram a separação daquelas espécies. McMurtry (1980) verificou que as variações morfológicas intra-específicas foram maiores entre 2 subespécies de Euseius addoensis (Van der Merwe \& Ryke) do que entre aquelas subespécies e uma população de Euseius citri (Van der Merwe \& Ryke).

Espécimes de Euseius mesembrinus (Dean) procedentes da Flórida e do Texas, Estados Unidos da América, apresentaram diferenças em relação ao comprimento de algumas setas. Esta variação foi atribuída a fatores geográficos ou nutricionais, já que foram verificadas apenas em indivíduos provenientes do campo, desaparecendo em condições de laboratório, onde as fontes de alimento e outros fatores ecológicos foram controlados (Abou-Setta et al., 1991).

Lofego (1998) verificou que algumas espécies de fitoseídeos apresentaram consideráveis variações morfológicas entre populações de diferentes regiões do Brasil. Variações de até $100 \%$ no comprimento de algumas setas do escudo dorsal de Euseius alatus DeLeon, dentro de uma mesma população, também foram constatadas por aquele autor.

Pequenas diferenças morfológicas entre populações de Euseius concordis (Chant) procedentes de Jaguariúna-SP e Petrolina-PE foram verificadas por Furtado 
(1997), podendo indicar a existência de 2 espécies morfologicamente muito próximas, mas biologicamente distintas. Para indivíduos de Euseius citrifolius Denmark \& Muma alimentados com diferentes dietas, a mesma autora também verificou pequenas variações nas dimensões das estruturas estudadas.

No processo reprodutivo conhecido como pseudo-arrenotoquia, já demonstrado para algumas espécies de fitoseídeos, os machos são haplóides em decorrência da perda de um conjunto de cromossomos de origem paterna, apresentando basicamente a mesma constituição genética que suas mães. Assim sendo, evidências sobre o processo reprodutivo em espécies de fitoseídeos podem ser obtidas através de estudos de caracterização morfológica dos descendentes de cruzamentos envolvendo populações com algum nível de diferenças morfológicas. A indicação da ocorrência da pseudoarrenotoquia em Euseius, com base em estudos morfológicos foram relatados por Congdon \& McMurtry (1988) e Furtado (1997). Entretanto, Perrot-Minnot \& Navajas (1995) obtiveram evidências da contribuição genética paterna na produção de machos haplóides, sugerindo que a incorporação do material genético paterno no embrião poderia ocorrer antes da eliminação do conjunto de cromossomos nos machos, ou que a perda do genoma paternal não seria total. Entretanto, são necessários estudos para a comprovação de que a espécie de fitoseídeo utilizada nesse trabalho se reproduz por pseudo-arrenotoquia.

As espécies utilizadas no presente estudo foram descritas de exemplares coletados na América do Sul. E. citrifolius foi descrito de espécimes coletados em Assunção, Paraguai, e E. concordis, de espécimes coletados em Concórdia, Entre Rios, Argentina. Além das descrições originais, informações complementares sobre a morfologia destas espécies foram apresentadas por Feres \& Moraes, (1998); Gondim Junior \& Moraes (2001); Lofego (1998); Moraes \& McMurtry (1983) e Moraes et al. (1991).

O presente trabalho teve por objetivo a determinação de variações morfológicas dentro e entre populações identificadas como E. citrifolius e E. concordis, provenientes de diferentes regiões do Brasil. 


\subsection{Material e Métodos}

A caracterização morfológica de populações identificadas preliminarmente como E. citrifolius e E. concordis foi realizada através de medições de estruturas consideradas importantes para a separação de espécies neste gênero.

Os substratos e locais de coleta de cada espécie foram: E. citrifolius: Bauhinia sp. em Arroio do Meio-RS (R), Coffea arabica L. em Campinas-SP (S) e Terminalia catappa L. em Petrolina-PE (P); E. concordis: Passiflora edulis Sims. f. flavicarpa Deg. em Arroio do Meio-RS (R), Manihot esculenta (Crantz) em Jaguariúna-SP (S), T. catappa em Petrolina-PE (P), Hevea brasiliensis Muell. Arg. em Pontes e Lacerda-MT (M) e C. arabica em Viçosa-MG (V). Os locais de coleta de E. citrifolius mais próximos entre si são Arroio do Meio e Campinas (aproximadamente $900 \mathrm{~km}$ em linha reta), e os locais mais distantes entre si são Arroio do Meio e Petrolina (aproximadamente $2.600 \mathrm{~km}$ ). Os locais de coleta de E. concordis mais próximos entre si são Jaguariúna e Viçosa (aproximadamente $500 \mathrm{~km}$ ), e os locais mais distantes entre si são Arroio do Meio e Petrolina. Observa-se na Figura 1 a localização de cada ponto de coleta.

Os ácaros foram montados em lâminas de microscopia com meio de Hoyer. As medições foram realizadas com auxílio de um microscópio óptico com contraste de fase e de uma ocular graduada.

Foram medidos 10 fêmeas e 10 machos adultos provenientes de colônias de manutenção de cada população estudada, cada uma iniciada com 50 a 70 indivíduos. Foram ainda medidos de 9 a 10 fêmeas e 2 a 10 machos adultos resultantes dos cruzamentos (fêmea x macho) PR, RP, PS e SP de E. citrifolius, e fêmeas e machos adultos resultantes dos cruzamentos RS, SR, MS, SM, MR, RM, VS, SV, RP, VP, SP e MP de E. concordis.

A avaliação das fêmeas constou de medições do comprimento e largura do escudo dorsal; comprimento, larguras anterior e posterior do escudo ventrianal; comprimento de macrosetas das pernas; distâncias entre as bases das setas esternais (ST1-ST3, ST2-ST2, ST5-ST5); comprimento das setas dorsais j1, j3, j4, j5, j6, J2, J5, 
z2, z4, Z1, Z4, Z5, s4, S2, S4, S5, r3, R1; comprimento do cálice da espermateca e comprimento dos dígitos fixo e móvel da quelícera. A avaliação dos machos constou das mesmas medições efetuadas para as fêmeas, com exceção do comprimento do cálice da espermateca, da largura posterior do escudo ventrianal, das distâncias entre as bases das setas esternais, e do comprimento dos dígitos fixo e móvel da quelícera; foi medido neste caso o comprimento do espermadáctilo (nomenclatura de Chant \& Yoshida-Shaul, 1991 e Rowell et al., 1978).

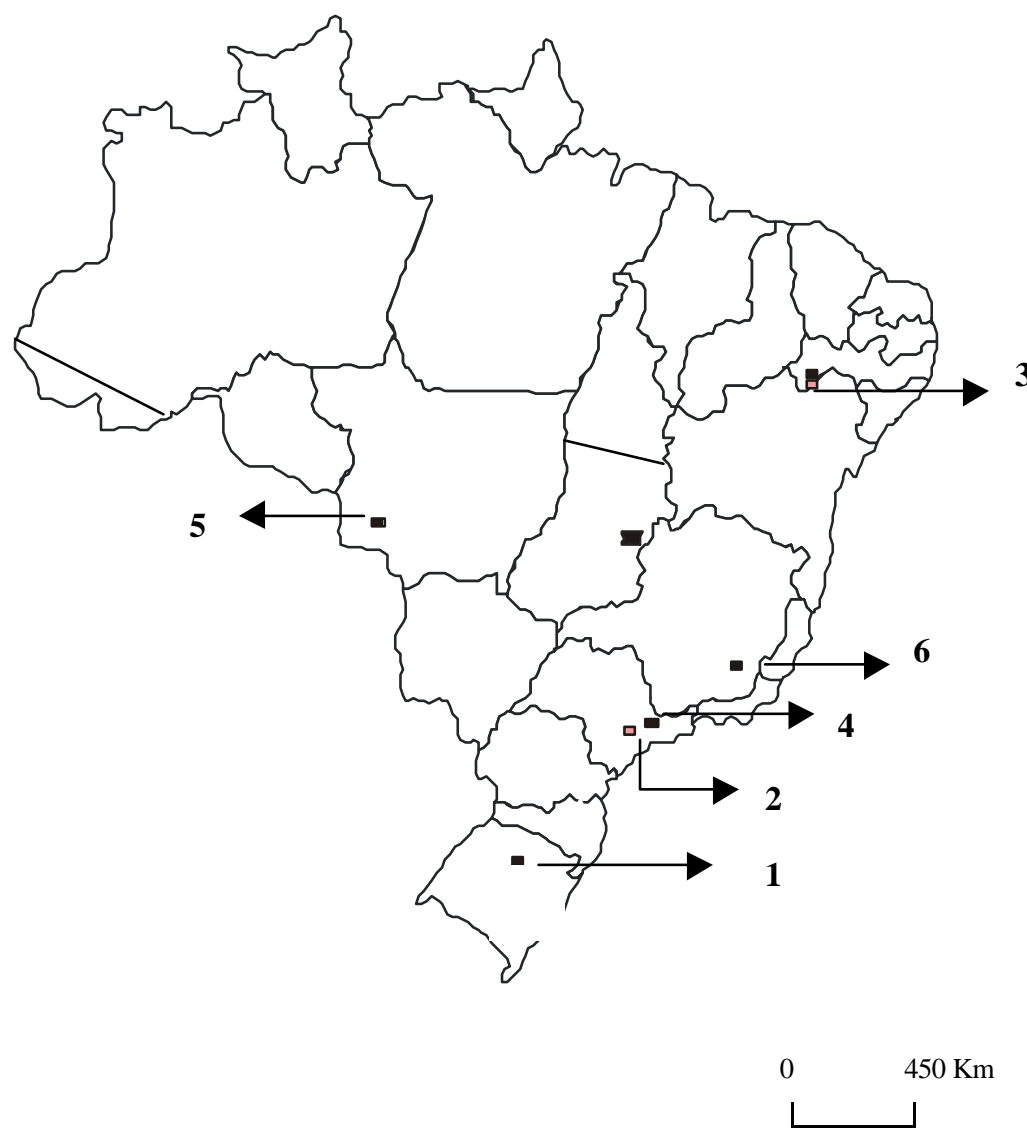

Figura 1 - Locais de coleta de populações de Euseius citrifolius: Arroio do MeioRS (1), Campinas-SP (2) e Petrolina-PE (3); e de E. concordis: de Arroio do Meio, Jaguariúna-SP (4), Petrolina, Pontes e Lacerda-MT (5) e Viçosa-MG (6). 


\subsection{Resultados}

O resultado do estudo morfológico das populações identificadas preliminarmente como E. citrifolius e E. concordis, bem como todos os dados de medições das estruturas constantes das avaliações são apresentadas a seguir.

\section{Euseius citrifolius}

As informações completas sobre as medições realizadas encontram-se em anexo (Anexo A. Tabelas 1 a 4).

Nas fêmeas, as setas j1, j3, z4, Z5, s4, S4 e S5, e as macrosetas do genu e do tarso da perna IV apresentaram maiores amplitudes de variação dentro de cada população (Anexo A. Tabela 1$)$. Verificou-se uma relação significativa $(\mathrm{P}<0,05)$ entre a dimensão média das setas e os valores das amplitudes de variação em cada população. Os coeficientes de correlação para as populações $\mathrm{R}, \mathrm{S}$ e $\mathrm{P}$ foram $0,81,0,83$ e 0,83 , respectivamente.

Pequenas diferenças foram encontradas entre fêmeas das diferentes populações em relação às medições de algumas estruturas. Entretanto, as setas j1, j3, S2 e S5 foram em média mais curtas nas fêmeas de Petrolina (Tabela 1). Ao mesmo tempo, aquelas fêmeas eram menores, conforme indicado pelas menores dimensões do escudo dorsal. Observou-se entretanto uma sobreposição parcial das amplitudes das dimensões do escudo dorsal e das setas citadas das diferentes populações.

As medições verificadas para as fêmeas de todas as populações estão de acordo com os dados apresentados por Moraes \& McMurtry (1983) para espécimes de $E$. citrifolius do nordeste do Brasil. As medições das estruturas das populações estudadas também estão de acordo com as medições de um parátipo depositado na Escola Superior de Agricultura "Luiz de Queiroz", coletado em Cecílio Baez, Paraguai, sobre Psidium guajava L., em 6 de janeiro de 1969 (Anexo A. Tabela 1). 
Tabela 1. Dimensões (mínimo-máximo) $(\mu \mathrm{m})$ de fêmeas de populações identificadas como Euseius citrifolius procedentes de Arroio do MeioRS (R), Campinas-SP (S) e Petrolina-PE (P). (n=10 para cada população).

\begin{tabular}{cccc}
\hline $\begin{array}{c}\text { Parâmetros } \\
\text { Morfológicos }\end{array}$ & R & S & P \\
\hline CED & $326(317-338)$ & $321(313-327)$ & $304(286-318)$ \\
LED & $233(221-246)$ & $230(224-240)$ & $220(213-230)$ \\
j1 & $25(24-27)$ & $27(26-27)$ & $23(20-24)$ \\
j3 & $25(22-27)$ & $23(22-24)$ & $21(16-24)$ \\
S2 & $18(16-19)$ & $18(16-19)$ & $16(14-16)$ \\
S5 & $26(19-30)$ & $25(22-27)$ & $22(20-23)$
\end{tabular}

'- CED, comprimento do escudo dorsal; LED, largura do escudo dorsal; j1, j3, S2 e S5 setas do escudo dorsal.

Nas fêmeas descendentes dos cruzamentos heterogâmicos realizados (PR, RP, PS e SP), verificou-se uma tendência em serem as setas j1, j3, S2 e S5 semelhantes às médias da população de Petrolina (Anexo A. Tabelas 1 e 3). As setas j3, Z5 e a macroseta do genu IV foram ligeiramente menores nos descendentes PR. As fêmeas cuja população materna era de Petrolina apresentavam escudos dorsal e ventrianal ligeiramente menores, semelhantemente ao que se observou para as fêmeas da população materna (Anexo A. Tabela 3). Por outro lado, praticamente em todos os descendentes de cruzamentos heterogâmicos, as amplitudes de variação de cada estrutura medida se sobrepuseram em relação às amplitudes das outras populações.

Nos machos, maiores amplitudes de variação dentro de cada população foram observadas em relação às dimensões das setas z2, z4, Z5 e s4, e das macrosetas do genu e do tarso da perna IV (Anexo A. Tabela 2). Verificou-se uma relação significativa ( $\mathrm{P}<$ 0,05) entre a dimensão média das setas e os valores das amplitudes de variação em cada população. Os coeficientes de correlação para as populações $R, S$ e $P$ foram respectivamente, $0,60,0,63$ e 0,90 . Na população $\mathrm{R}$ a seta $\mathrm{z} 4$ apresentou o maior valor para a amplitude de variação, embora outras setas de maior dimensão que a z4 apresentassem amplitudes de variação inferiores.

Foram encontradas pequenas diferenças entre machos das diferentes populações em relação às medições de algumas estruturas. Nos machos de Petrolina, as setas j3, z2, 
z4, Z5, s4, S2, S5 e as macrosetas da tíbia III e do genu IV foram em média mais curtas que nos machos de outros locais (Tabela 2). Entretanto, aqueles eram de tamanho um pouco menores que os machos dos outros locais. Observou-se entretanto uma sobreposição parcial das amplitudes das dimensões do escudo dorsal e das setas citadas entre as diferentes populações.

Nos machos PR e PS, as dimensões das estruturas foram semelhantes entre si e em relação à população materna. Entretanto, as setas j3, z2, z4, Z5, s4, S2, S4, S5, e as macrosetas da tíbia III e do genu IV foram em média notoriamente mais curtas em relação às populações paternas $\mathrm{R}$ e $\mathrm{S}$. Nos machos $\mathrm{PR}$, as macrosetas do genu III, da tíbia IV e tarso IV, foram expressivamente mais curtas em relação à população paterna (Tabela 2).

Tabela 2. Dimensões (mínimo-máximo) $(\mu \mathrm{m})$ de machos de populações identificadas como Euseius citrifolius procedentes de Arroio do Meio-RS (R), Campinas-SP (S), Petrolina-PE (P) e de cruzamentos entre essas populações. ( $\mathrm{n}=10$ para cada população e combinação).

\begin{tabular}{|c|c|c|c|c|c|c|c|}
\hline $\begin{array}{l}\text { Parâmetros } \\
\text { morfológicos }\end{array}$ & $\mathrm{R}$ & $\mathrm{S}$ & $\mathrm{P}$ & $\mathrm{PR}^{2}$ & $\mathrm{RP}^{3}$ & $\mathrm{PS}^{4}$ & $\mathrm{SP}^{5}$ \\
\hline CED & $242(230-248)$ & $243(235-251)$ & $234(221-240)$ & $230(219-243)$ & $245(236-270)$ & $240(230-254)$ & $247(238-257)$ \\
\hline LED & 194(186-202) & $183(176-189)$ & $173(159-184)$ & $183(167-189)$ & $190(176-200)$ & $190(173-200)$ & $190(181-197)$ \\
\hline $\mathrm{j} 1$ & - & - & - & $18(16-19)$ & 21(19-22) & $17(14-19)$ & $20(19-22)$ \\
\hline j3 & $24(22-27)$ & $25(22-27)$ & $20(19-22)$ & $20(19-22)$ & $22(19-27)$ & $19(16-22)$ & $23(22-24)$ \\
\hline $\mathrm{z} 2$ & $19(16-22)$ & $19(16-22)$ & $15(14-16)$ & $16(14-16)$ & $18(16-19)$ & $15(14-16)$ & - \\
\hline z4 & $19(16-27)$ & $19(16-22)$ & $16(15-18)$ & $16(14-19)$ & $18(16-19)$ & $16(16-16)$ & - \\
\hline Z5 & $47(40-49)$ & $48(45-51)$ & $44(40-51)$ & $40(35-43)$ & $47(42-51)$ & $41(38-43)$ & $44(40-46)$ \\
\hline s4 & $28(24-32)$ & $28(24-32)$ & $24(22-27)$ & $24(19-27)$ & $26(24-27)$ & $23(19-24)$ & $25(24-30)$ \\
\hline $\mathrm{S} 2$ & $18(16-19)$ & $17(14-19)$ & $15(14-16)$ & $14(11-16)$ & $17(16-19)$ & $14(14-16)$ & - \\
\hline S4 & $19(16-19)$ & $18(15-20)$ & $17(16-19)$ & $16(14-19)$ & $20(16-24)$ & $15(14-16)$ & $20(16-24)$ \\
\hline S5 & $23(19-24)$ & $22(19-26)$ & $19(18-20)$ & $19(16-22)$ & $23(19-30)$ & $19(19-22)$ & $23(20-27)$ \\
\hline Sge III & $20(19-22)$ & $19(18-19)$ & - & $15(14-16)$ & - & $17(16-19)$ & - \\
\hline Sti III & $19(19-19)$ & $18(16-19)$ & $16(14-18)$ & $16(14-19)$ & $18(16-19)$ & $16(14-16)$ & $19(16-19)$ \\
\hline Sge IV & $28(27-30)$ & $29(27-31)$ & $24(19-27)$ & $25(22-27)$ & $28(27-30)$ & $26(24-27)$ & $28(27-30)$ \\
\hline Sti IV & $24(22-27)$ & $24(22-27)$ & - & $20(19-22)$ & - & $22(22-24)$ & - \\
\hline St IV & $43(40-49)$ & $41(38-46)$ & - & $38(35-40)$ & - & $42(40-46)$ & - \\
\hline \multicolumn{8}{|c|}{$\begin{array}{l}\text { '1- CED, comprimento do escudo dorsal; LED, largura do escudo dorsal; j1, j3, z2, z4, Z5, s4, S2, S4, S5, setas localizadas no } \\
\text { escudo dorsal; Sge III, macroseta do genu da perna III; Sti III, macroseta da tíbia da perna III; Sge IV, macroseta do genu da } \\
\text { perna IV; Sti IV, macroseta da tíbia da perna IV; St IV, macroseta do tarso da perna IV. } \\
2 \text { - Machos descendentes de fêmeas de Petrolina e machos de Arroio do Meio } \\
3 \text { - Machos descendentes de fêmeas de Arroio do Meio e machos de Petrolina } \\
4 \text { - Machos descendentes de fêmeas de Petrolina e machos de Campinas } \\
5 \text { - Machos descendentes de fêmeas de Campinas e machos de Petrolina. }\end{array}$} \\
\hline
\end{tabular}


Nos machos RP, as medidas das estruturas foram semelhantes às dimensões dos machos da população materna, enquanto as setas z2, z4, Z5, S2, S4, S5 e a macroseta do genu IV foram em média mais longas que nos machos da população paterna, embora tenha se observado a sobreposição das amplitudes de variação correspondentes (Tabela 2).

Nos machos SP, as dimensões das estruturas foram semelhantes àquelas dos machos da população materna, enquanto as setas j3, S4, S5 e a macroseta do genu IV foram em média mais longas que nos machos da população paterna, embora os extremos inferiores das amplitudes de variação dessas estruturas nos machos SP estivessem próximos aos extremos superiores das amplitude correspondentes dos machos da população paterna (Tabela 2). Nos machos PR e PS, as setas j1, j3, Z5, s4, S4, S5 e as macrosetas da tíbia III e genu IV foram em média mais curtas que nos machos RP e SP. Entretanto, também neste caso os extremos superiores das amplitudes de variação destas estruturas para os machos PR e PS estiveram sempre próximos aos extremos inferiores correspondentes dos machos RP e SP.

\section{Euseius concordis}

As informações completas sobre as medições realizadas encontram-se em anexo (Anexo B. Tabelas 1 a 6).

Nas fêmeas, as maiores amplitudes de variação dentro de cada população foram verificadas em relação às setas j1, z2, z4, Z5, s4 e as macrosetas do genu das pernas III e IV, da tíbia das pernas III e IV e do tarso IV (Anexo B. Tabela 1). Verificou-se uma relação significativa $(\mathrm{P}<0,05)$ entre as dimensões médias das setas e os valores das amplitudes de variação dentro de cada população. Maiores coeficientes foram obtidos nas populações de Petrolina $(0,80)$ e Jaguariúna $(0,73)$, para as demais populações este coeficiente variou de 0,47 a 0,62 .

As setas j3, z2, z4, s4 e a macroseta do genu IV das fêmeas de Jaguariúna foram em média mais curtas que nas fêmeas das outras populações, embora as fêmeas das populações $\mathrm{S}, \mathrm{M}$ e $\mathrm{V}$ fossem aproximadamente do mesmo tamanho, como indicado pelas dimensões do escudo dorsal (Tabela 3). As maiores diferenças foram observadas 
para as setas z2 e z4, que em alguns ácaros de Petrolina foram até 2 ou mais vezes maiores que em alguns ácaros de Jaguariúna. Por outro lado, os extremos superiores das amplitudes de variação destas estruturas para a população de Jaguariúna estiveram sempre próximos aos extremos inferiores correspondentes das outras populações. Não houve entretanto sobreposição entre as amplitudes de variação das setas j3, z4 e s4 entre as populações de Jaguariúna e Petrolina.

As medições verificadas para as fêmeas de todas as populações considerando-se os valores das amplitudes de variação, estão de acordo com os dados apresentados por Moraes \& McMurtry (1983) e em relação às medições do holótipo (McMurtry, 1983).

Em geral, as dimensões das estruturas consideradas foram muito semelhantes entre as fêmeas descendentes dos cruzamentos RS, MR, RM e VS, e as respectivas populações parentais (Anexo B. Tabelas 1 e 3). Entretanto as dimensões das setas j3, z2, z4 e s4 apresentaram médias sempre superiores nas populações parentais $\mathrm{M}$ e $\mathrm{R}$, em relação às dimensões das estruturas correspondentes nos descendentes MR e RM, embora tenha se observado a sobreposição das amplitudes de variação correspondentes (Tabela 3). Ainda com relação às mesmas setas, as fêmeas RS e VS apresentaram dimensões médias inferiores àquelas das fêmeas das populações maternais correspondentes, e superiores àquelas das fêmeas da população paternal, embora as amplitudes de variação também se sobrepusessem.

Nos machos, maiores amplitudes de variação foram observadas em relação às setas j1, z4, Z5, s4, S5 e macrosetas do genu da perna IV e do tarso IV (Anexo B. Tabela 2). Verificou-se uma relação significativa $(\mathrm{P}<0,05)$ entre as dimensões média das setas e os valores das amplitudes de variação para cada população. Maiores coeficientes de correlação foram obtidos nas populações de Jaguariúna $(0,76)$ e Arroio do Meio $(0,70)$; nas demais populações este coeficiente variou de 0,54 a 0,64.

A maior parte das estruturas não apresentou diferenças marcantes entre as distintas populações. Na população de Jaguariúna, apenas a seta z4 apresentou-se marcadamente curta, mas o extremo superior de sua amplitude de variação coincidiu com o extremo inferior das amplitudes correspondentes das populações de Petrolina e 
Tabela 3. Dimensões (mínimo-máximo) $(\mu \mathrm{m})$ de fêmeas de populações identificadas como Euseius concordis procedentes de Arroio do Meio-RS (R), Jaguariúna-SP (S), Petrolina-PE (P), Pontes e Lacerda-MT (M) e Viçosa-MG (V). (n= 10 para cada população e combinação).

\begin{tabular}{|c|c|c|c|c|c|c|c|c|c|}
\hline $\begin{array}{l}\text { Parâmetros } \\
\text { morfológicos }^{1}\end{array}$ & $\mathrm{R}$ & $\mathrm{S}$ & $\mathrm{P}$ & $\mathrm{M}$ & $\mathrm{V}$ & $\mathrm{MR}^{2}$ & $\mathrm{RM}^{3}$ & $\begin{array}{l}\mathrm{RS}^{4} \\
\mathrm{n}=9\end{array}$ & $\mathrm{VS}^{5}$ \\
\hline CED & $326(313-340)$ & $315(302-332)$ & $307(292-338)$ & $315(292-325)$ & $312(300-321)$ & - & - & - & - \\
\hline LED & $233(219-248)$ & $232(224-246)$ & $224(204-246)$ & $227(213-236)$ & $222(211-230)$ & - & - & - & - \\
\hline j3 & $36(32-38)$ & $29(27-32)$ & $38(35-43)$ & $37(32-40)$ & $37(35-41)$ & $32(27-35)$ & $31(30-32)$ & $30(30-35)$ & $33(28-35)$ \\
\hline $\mathrm{z} 2$ & $20(16-24)$ & $16(14-19)$ & $23(19-28)$ & $18(14-22)$ & $20(19-22)$ & $16(14-19)$ & $16(14-19)$ & $18(16-22)$ & $18(16-19)$ \\
\hline $\mathrm{z} 4$ & $36(31-38)$ & $28(22-32)$ & $40(35-49)$ & $33(30-38)$ & $34(30-38)$ & $28(24-30)$ & $27(24-28)$ & $30(27-32)$ & $30(27-35)$ \\
\hline s4 & $52(49-54)$ & $43(38-49)$ & $55(51-62)$ & $51(49-54)$ & $50(49-54)$ & $49(46-51)$ & $47(43-54)$ & $48(46-50)$ & $47(46-49)$ \\
\hline Sge IV & $40(38-43)$ & $37(35-38)$ & $39(34-49)$ & $40(39-43)$ & $41(38-41)$ & - & - & - & - \\
\hline
\end{tabular}

1'- CED, comprimento do escudo dorsal; LED, largura do escudo dorsal; j3, z2, z4, s4, setas do escudo dorsal; Sge IV, macroseta do genu da perna IV.

- Fêmeas descendentes de fêmeas de Pontes e Lacerda e machos de Arroio do Meio

3 - Fêmeas descendentes de fêmeas de Arroio do Meio e machos de Pontes e Lacerda

${ }^{4}$ - Fêmeas descendentes de Arroio do Meio e machos de Jaguariúna

5 - Fêmeas descendentes de Viçosa e machos de Jaguariúna. 
Arroio do Meio e foi ainda maior que o extremo inferior das amplitudes correspondentes das populações de Pontes e Lacerda e Viçosa. (Tabela 4).

Nos machos RS, as medidas das estruturas pouco variaram em relação à população materna (Anexo B. Tabelas 2 e 4). Entretanto, as setas z4, s4, S4 e S5 apresentaram dimensões médias superiores às médias da população paternal, mas as amplitudes de variação destas setas se sobrepuseram (Tabela 4).

Também nos machos SR, as medidas das estruturas pouco variaram em relação à população materna. A seta $\mathrm{s} 4$ nos machos SR foi em média mais curta que a mesma nos machos da população paterna, mas o extremo superior de amplitude de variação de SR coincidiu com o limite inferior da amplitude correspondente da população paterna (Tabela 4).

Os machos SM e MS, apresentaram as dimensões da maior parte das estruturas semelhantes àquelas dos machos das populações parentais (Anexo B. Tabelas 2 e 4), com exceção da seta j3, que foi em média mais curta nos machos SM que nos machos da população de Pontes e Lacerda, não havendo sobreposição das amplitudes de variação (Tabela 4).

Também os machos MR e RM apresentaram as dimensões da maior parte das estruturas semelhantes àquelas dos machos das populações parentais (Anexo B. Tabelas 2 e 3), com exceção das setas z4, Z5, S4 e S5, que foram em média mais curtas nos machos MR que nos machos da população paterna. As amplitudes das dimensões das setas S4 e S5 dos machos MR não se sobrepuseram às amplitudes correspondentes dos machos da população paterna (Tabela 4).

Nos machos VS, as dimensões foram praticamente as mesmas daquelas dos machos da população materna. Entretanto, as setas z4 e s4 foram em média mais longas que nos machos da população paterna, com as amplitudes de variação se sobrepondo. Resultado semelhante foi verificado com os machos SV, em relação aos machos da geração materna, enquanto a seta z2 foi em média mais curta que nos machos da população paterna, com as amplitudes de variação não se sobrepondo (Tabela 4). 
Tabela 4. Dimensões (mínimo-máximo) $(\mu \mathrm{m})$ de machos de populações identificadas como Euseius concordis e de descendentes de cruzamentos entre essas populações procedentes de Arroio do Meio-RS (R), Jaguariúna-SP (S), Petrolina-PE (P), Pontes e Lacerda-MT (M) e Viçosa-MG (V). (n=10 para cada população e combinação).

\begin{tabular}{|c|c|c|c|c|c|c|c|c|c|c|c|c|}
\hline $\begin{array}{c}\text { Parâmetros } \\
\text { morfológicos }\end{array}$ & $\mathrm{R}$ & $S$ & $P$ & $\mathrm{M}$ & $\mathrm{V}$ & $\mathrm{RS}^{2}$ & $\mathrm{SR}^{3}$ & $\mathrm{SM}^{4}$ & $\mathrm{MR}^{5}$ & $\mathrm{VS}^{6}$ & $\mathrm{SV}^{7}$ & $\mathrm{SP}^{8}$ \\
\hline CED & $248(239-255)$ & $242(235-248)$ & $233(230-238)$ & $235(216-247)$ & $244(235-254)$ & - & - & - & - & - & - & - \\
\hline j3 & - & - & - & $32(30-32)$ & - & - & - & 27 (24-28) & & & & \\
\hline $\mathrm{z} 2$ & - & - & 25 (22-27) & - & $22(20-24)$ & - & - & - & - & - & $18(16-19)$ & $17(16-19)$ \\
\hline $\mathrm{z} 4$ & $31(30-36)$ & $27(22-30)$ & $32(30-36)$ & $31(27-32)$ & $31(27-32)$ & $31(30-32)$ & - & & $27(26-30)$ & $32(30-40)$ & - & $27(24-27)$ \\
\hline s4 & $40(39-43)$ & $35(32-40)$ & - & - & - & $40(38-43)$ & $35(30-38)$ & & - & $39(38-40)$ & - & - \\
\hline S4 & $20(18-22)$ & $17(14-19)$ & - & - & - & $20(19-22)$ & - & & $15(14-16)$ & - & - & - \\
\hline S5 & $20(19-22)$ & $18(14-22)$ & - & - & - & $21(19-22)$ & - & & $16(14-18)$ & - & - & - \\
\hline
\end{tabular}


Nos machos RP, as dimensões das estruturas pouco variaram em relação às estruturas correspondentes nos machos das populações parentais. Resultado semelhante foi obtido com os machos VP e MP (Anexo B. Tabelas 2 e 6).

As dimensões das estruturas dos machos SP, foram muito semelhantes às dimensões dos machos da população materna (Anexo B. Tabelas 2 e 6), enquanto as setas z2 e z4 apresentaram-se marcadamente mais curtas que nos machos da população paterna, sem haver sobreposição das amplitudes de variação (Tabela 4).

\subsection{Discussão}

A correlação significativa verificada para cada população de E.citrifolius sugere que as amplitudes de variação estão relacionadas com a comprimento das estruturas. Assim sendo, maiores amplitudes de variação são esperadas para as setas e macrosetas de maior comprimento e vice-versa. Portanto, as setas j1, j3, z2, z4, Z5, s4, e as macrosetas do genu e do tarso IV devem apresentar maiores amplitudes de variação. Entretanto, a seta z4 na população R fugiu à regra. Apesar desta seta apresentar menor dimensão que as setas j3, Z5 e s4, o valor da amplitude de variação foi marcadamente superior.

Apesar dos exemplares de E. citrifolius avaliados neste trabalho serem procedentes de 3 regiões geograficamente distantes, não foram constatadas diferenças expressivas nas dimensões das estruturas entre as populações. Consequentemente, também os indivíduos procedentes dos cruzamentos interpopulacionais apresentaram pequenas variações em relação às populações parentais.

Lofego (1998) analisou 30 fêmeas de E. citrifolius procedentes de diferentes regiões e diferentes substratos, não relatando acentuadas variações morfológicas. Furtado (1997) considerou a possibilidade de que o alimento pudesse interferir nas dimensões de diferentes estruturas de E. citrifolius, sob condições de laboratório. Não encontrou, entretanto, nenhuma diferença considerável entre fêmeas criadas em diferentes tipos de alimento. 
As maiores dimensões verificadas neste estudo para algumas setas do escudo dorsal de fêmeas em relação às dimensões das setas correspondentes no holótipo também foram observadas por Feres \& Moraes (1998), Gondim Junior \& Moraes (2001) e Moraes \& McMurtry (1983), para exemplares de São Paulo e do nordeste do Brasil.

Wysoki \& McMurtry (1977) verificaram que E. citrifolius apresenta machos com 4 e fêmeas com 8 cromossomos. Se considerarmos que os machos haplóides de $E$. citrifolius apresentam basicamente a mesma constituição genética que sua mãe, de acordo com o processo reprodutivo de pseudo-arrenotoquia, as semelhanças verificadas nas dimensões médias dos parâmetros estudados entre os machos PR, RP, PS e SP e os machos das populações maternais seriam esperadas.

A tendência de fêmeas e machos de E. concordis de Jaguariúna apresentarem dimensões menores de algumas estruturas também foi observada por Furtado (1997) quando comparando exemplares coletados naquele local com exemplares coletados em Petrolina. Embora as amplitudes de variação de algumas setas não tenham se sobreposto tanto neste estudo quanto no estudo conduzido por Furtado (1997), deve-se considerar que no máximo 10 indivíduos foram medidos neste trabalho o que pode ter resultado em uma possível subestimativa deste parâmetro. Em uma análise com um número maior de exemplares poderia ter sido possível observar a sobreposição das amplitudes de variação.

Os resultados obtidos neste trabalho indicam que E. concordis também se reproduz pelo processo de pseudo-arrenotoquia, seguindo o padrão de machos haplóides e fêmeas diplóides, como foi sugerido por Furtado (1997). Nas fêmeas RS, MR, RM e VS, como era esperado, as dimensões médias dos parâmetros estudados não apresentaram variações expressivas quando comparadas com as dimensões de fêmeas de populações parentais; as setas j3, z2, z4 e s4 apresentaram pequenas diferenças, mas as amplitudes de variação se sobrepuseram em todas as comparações. As variações nas medições das setas z2 e z4 verificadas neste trabalho, já haviam sido constatadas por Lofego (1998) quando da análise morfológica de alguns exemplares dessa espécie procedentes de São Paulo e da região nordeste. 
As semelhanças verificadas entre machos SR, RS, SR, VS, SV e SP, e os machos das populações maternais também seriam esperadas, no processo de reprodução conhecido como pseudo-arrenotoquia.

O processo de pseudo-arrenotoquia também foi sugerido por Congdon \& McMurtry (1988) para outras espécies de Euseius. Esses autores verificaram que machos resultantes do cruzamento de fêmeas E. hibisci e machos E. quetzali procedentes da Califórnia foram semelhantes aos machos de E. hibisci, sugerindo que E. hibisci se reproduz por pseudo-arrenotoquia (parahaploidia).

A comparação dos dados morfológicos das populações estudadas neste trabalho com os dados de descrições disponíveis na literatura para E. citrifolius confirmam que as populações procedentes de Arroio do Meio, Campinas e Petrolina pertencem à esta espécie. Do mesmo modo, as populações procedentes de Arroio do Meio, Jaguariúna, Petrolina, Pontes e Lacerda e Viçosa pertencem à espécie E. concordis. As variações observadas nas medições das estruturas das populações de E. citrifolius e E. concordis permitiram a diferenciação morfológica das populações de E. citrifolius de Petrolina e de E. concordis de Jaguariúna, das demais populações das espécies estudadas correspondentes. Entretanto, uma análise morfológica com um número muito reduzido de exemplares dificultaria a identificação da espécie ao nível de população, devido as sobreposições das dimensões das estruturas empregadas na identificação de Euseius.

\subsection{Conclusões}

- As populações de fitoseídeos coletadas em Bauhinia sp., C. arabica e T. catappa, procedentes de Arroio do Meio-RS, Campinas-SP e Petrolina-PE, respectivamente, pertencem à espécie E. citrifolius. 
- As populações de fitoseídeos coletadas em P. edulis f. flavicarpa, M. esculenta, $T$. catappa, H. brasiliensis e C. arabica, procedentes respectivamente de Arroio do Meio, Jaguariúna-SP, Petrolina, Pontes e Lacerda-MT e Viçosa-MG, pertencem à espécie E. concordis.

- A análise de um número muito reduzido de indivíduos identificados como $E$. citrifolius, coletados em Arroio do Meio, Campinas e Petrolina, ou de E. concordis coletados em Arroio do Meio, Jaguariúna, Petrolina, Pontes e Lacerda e Viçosa não permite identificar a espécie ao nível de população, tendo em vista as sobreposições das dimensões das estruturas usadas na identificação de Euseius.

- Os fitoseídeos E. citrifolius e E. concordis se reproduzem através do processo de pseudo-arrenotoquia. 


\section{COMPATIBILIDADE REPRODUTIVA ENTRE POPULAÇÕES IDENTIFICADAS COMO Euseius citrifolius (ACARI, PHYTOSEIIDAE)}

\section{RESUMO}

O objetivo deste estudo foi verificar a compatibilidade reprodutiva entre algumas populações identificadas através de caracteres morfológicos como Euseius citrifolius Denmark \& Muma, para comprovação de que pertencem a uma mesma espécie. Este trabalho complementa o estudo realizado no capítulo 3. As populações foram coletadas de Bauhinia sp. em Arroio do Meio-RS, Coffea arabica L. em Campinas-SP e Terminalia catappa L. em Petrolina-PE. Cruzamentos e retrocruzamentos homogâmicos e heterogâmicos foram realizados para avaliar a reprodução destes ácaros durante um período de 10 dias. Os níveis de oviposição nos cruzamentos homogâmicos foram maiores que nos cruzamentos heterogâmicos. Observou-se incompatibilidade reprodutiva parcial nos cruzamentos heterogâmicos envolvendo fêmeas de Petrolina; as fêmeas híbridas produziram poucos ovos e inviáveis quando retrocruzadas com machos das populações parentais. Os resultados obtidos indicaram que as populações estudadas pertencem a uma mesma espécie. 


\section{REPRODUCTIVE COMPATIBILITY BETWEEN POPULATIONS IDENTIFIED AS Euseius citrifolius (ACARI, PHYTOSEIIDAE)}

\section{SUMMARY}

The objective of this study was to verify the reproductive compatibility between populations of phytoseiid mites identified as Euseius citrifolius Denmark \& Muma according to their morphological characteristics, to ascertain that they belonged to a same species. This work complements the work reported in chapter 3. Populations were collected from Bauhinia sp. in Arroio do Meio-RS, Coffea arabica L. in Campinas-SP and Terminalia catappa L. in Petrolina-PE. Homogamic and heterogamic crosses and backcrosses were conducted to evaluate reproduction for a period of 10 days. Oviposition rates in homogamic crosses were generally higher than in heterogamic crosses. Partial incompatibility was observed in heterogamic crosses involving females from Petrolina; progeny produced just a few, unviable eggs when backcrossed with males of the parental populations. Males from Petrolina produced viable offspring when crossed with females from Arroio do Meio or Campinas. The results of this study indicated that the populations studied belong to a same species.

\subsection{Introdução}

Os fitoseídeos constituem a família de ácaros predadores de ácaros fitófagos mais reportada na literatura. Esses predadores vêm sendo utilizados em condições de campo e de casa-de-vegetação no controle de ácaros pragas, com vários relatos de sucessos (Bellotti et al., 1999; International Institute of Tropical Agriculture, 1995; Marshall et al., 2001; McMurtry, 1982 e 1992; Rasmy \& Ellaithy, 1988). 
A identificação de fitoseídeos é normalmente feita com base em considerações morfológicas. Os caracteres morfológicos nem sempre são suficientes para a separação de espécies muito próximas. Para o esclarecimento de certas dúvidas, o taxonomista freqüentemente considera aspectos ecológicos e biológicos. Nos últimos anos, o uso de uma nova ferramenta, a caracterização molecular, também tem sido utilizada (Congdon \& McMurtry, 1985 e 1986; McMurtry, 1980; Moraes, 1987; Navajas \& Fenton, 2000; Navajas et al., 1999).

Vários trabalhos de cruzamentos para o estudo da compatibilidade reprodutiva têm sido realizados entre populações consideradas da mesma espécie, provenientes de diferentes hospedeiros e/ou áreas geográficas (Abou-Setta et al., 1991; Croft, 1970; Hoying \& Croft, 1977 e McMurtry, 1980). Trabalhos envolvendo a combinação de caracteres morfológicos, estudos biológicos e moleculares também vêm sendo realizados no estudo de ácaros da família Tetranychidae (Navajas et al., 1992, 1994 e 1997).

Euseius citrifolius Denmark \& Muma tem sido relatado no nordeste, sudeste e sul do Brasil, sobre uma diversidade de plantas (Feres, 2000; Feres \& Moraes, 1998; Ferla \& Moraes,1998; Furtado, 1997; Gondim Junior \& Moraes, 2001; Moraes \& McMurtry, 1983; Moraes et al., 1986; Moreira, 1993; Pallini Filho et al., 1992; Zacarias, 2001). Estas identificações foram sempre baseadas em avaliações morfológicas, tendo-se em algumas destas publicações mencionado variações morfológicas entre distintas populações (Feres \& Moraes, 1998; Gondim junior \& Moraes, 2001).

As populações de E. citrifolius consideradas neste trabalho foram caracterizadas morfologicamente no capítulo 3. As variações observadas nas medições das estruturas permitiram a diferenciação morfológica da população de Petrolina das demais populações estudadas, apesar de não serem constatadas diferenças tão expressivas nas dimensões das estruturas e dos exemplares avaliados serem procedentes de regiões geograficamente distantes entre si.

Este trabalho foi realizado para verificar a compatibilidade reprodutiva entre populações de E. citrifolius consideradas no capítulo 3, coletadas em regiões distantes do país, para a comprovação de que pertencem a uma mesma espécie. 


\subsection{Material e Métodos}

Colônias de E. citrifolius foram estabelecidas a partir de espécimes coletados de Bauhinia sp. em Arroio do Meio-RS (R), Coffea arabica L. em Campinas-SP (S) e Terminalia catappa L. em Petrolina-PE (P). A localização dos pontos de coleta, assim como o número de indivíduos para o início das colônias foram apresentados no capítulo 3. As colônias foram mantidas em câmaras climatizadas, a $25 \pm 1{ }^{\circ} \mathrm{C}, 70 \pm 5 \%$ de umidade relativa e $12 \mathrm{~h}$ de fotofase, no interior de bandejas plásticas $(20 \times 15 \times 5 \mathrm{~cm})$, sobre folhas de feijão-de-porco (Canavalia ensiformis DC.) colocadas com a superfície abaxial para cima sobre um pedaço de espuma de náilon. As bordas das folhas foram cobertas com tiras de algodão hidrófilo, que também tocavam a espuma subjacente. Para evitar a fuga dos ácaros e a dessecação das folhas, a espuma foi umedecida diariamente com água destilada. Cada bandeja foi coberta com uma placa de vidro, deixando-se uma abertura para a aeração, colocando-se um pedaço de papelão sobre a placa de vidro para reduzir a luminosidade. Os ácaros foram transferidos para novas folhas a cada 30 dias. Foram alimentados com pólen de taboa (Typha angustifolia L.), adicionado em dias alternados, coletado no máximo 60 dias antes da utilização e mantido a aproximadamente $10^{\circ} \mathrm{C}$.

Cruzamentos: Para o início dos testes de cruzamentos, aproximadamente 100 fêmeas de cada população foram transferidas para unidades semelhantes às descritas anteriormente, sendo adicionado pólen de taboa como alimento, coletado e mantido nas mesmas condições já citadas anteriormente. Após 12 horas da transferência dos ácaros, os ovos depositados foram retirados com auxílio de um pincel, sob microscópio estereoscópico, e transferidos para outras unidades, semelhantes às usadas para as colônias de manutenção. Após 4 dias, as protoninfas e/ou deutoninfas resultantes foram individualizadas em unidades de criação constituídas de um recipiente transparente de acrílico $(2,5 \mathrm{~cm}$ de diâmetro x 1,3 cm de altura), no interior do qual foi colocado um disco de papel de filtro umedecido com água destilada, e sobre este, um disco de folha de feijão-de-porco, com a superfície abaxial voltada para cima. Para evitar a fuga dos 
ácaros, os recipientes foram vedados com uma película transparente de polivinilcloreto (Majipack $\left.{ }^{\circledR}\right)$. Os ácaros foram alimentados em dias alternados com pólen de taboa.

Após a emergência dos adultos e para cada população estudada, 10 fêmeas virgens foram mantidas isoladas em unidades de criação para verificar se fêmeas não acasaladas ovipositariam. Paralelamente, foram formados pelo menos 10 casais homogâmicos e 10 casais heterogâmicos, correspondentes às possíveis combinações das populações, com exceção das populações de Arroio do Meio e Campinas que não foram cruzadas entre si. Em todos os casos, o macho de cada casal foi sempre retirado da colônia de manutenção correspondente. Quando da morte de um macho, este era substituído por outro proveniente da mesma colônia.

Os casais foram mantidos por 10 dias, sendo os ovos obtidos agrupados e transferidos diariamente para novas unidades de criação semelhantes às citadas anteriormente para os cruzamentos, oferecendo-se pólen de taboa como alimento em dias alternados. Após 4 dias, as ninfas obtidas destes ovos foram isoladas em unidades de criação até a emergência dos adultos para determinação da razão sexual e utilização nos retrocruzamentos. O número de casais para cada retrocruzamento variou em função do número de machos e fêmeas obtidos. Os indivíduos obtidos dos retrocruzamentos foram mantidos de forma semelhante à descrita para os indivíduos obtidos dos cruzamentos, até atingirem a fase adulta, para determinação do sexo. Nos cálculos de oviposição, foram considerados somente os casais para os quais as fêmeas sobreviveram no mínimo 4 dias. $\mathrm{O}$ trabalho foi realizado em câmaras climatizadas, a $25 \pm 1{ }^{\circ} \mathrm{C}, 70 \pm 5 \%$ de umidade relativa e 12 horas de fotofase.

\subsection{Resultados}

Fêmeas virgens das diferentes populações não ovipositaram durante o período de observação. 
Nos cruzamentos e retrocruzamentos homogâmicos, $100 \%$ das fêmeas ovipositaram, e a oviposição média diária variou de 1,0 a 1,5 e de 0,8 a 1,9, respectivamente (Tabela 5). A proporção média de fêmeas variou de 29,4 a 54,1\% nos cruzamentos e de 31,4 a $55,0 \%$, nos retrocruzamentos.

Tabela 5. Resultados de cruzamentos e retrocruzamentos homogâmicos, no período de 10 dias, de populações de Euseius citrifolius procedentes de Campinas-SP (S), Arroio do Meio-RS (R) e Petrolina-PE (P), a $25 \pm 1{ }^{\circ} \mathrm{C}$, $70 \pm 5 \%$ de umidade relativa e $12 \mathrm{~h}$ de fotofase.

\begin{tabular}{|c|c|c|c|c|c|}
\hline$q \times \sigma^{\lambda}$ & $\mathrm{N}^{0}$ casais & $\begin{array}{c}\text { \% Fêmeas } \\
\text { ovipositando }\end{array}$ & $\begin{array}{c}\text { Total de } \\
\text { ovos }\end{array}$ & $\begin{array}{c}\text { Ovos/ }+ \text { /dia } \\
( \pm \mathrm{EP})\end{array}$ & $\begin{array}{c}\text { Razão sexual } \\
\text { (\% fêmeas) }\end{array}$ \\
\hline$S \times S$ & 7 & 100 & 80 & $1,5 \pm 0,2$ & 29,4 \\
\hline $\mathrm{R} \times \mathrm{R}$ & 10 & 100 & 93 & $1,0 \pm 0,3$ & 54,1 \\
\hline $\mathrm{P} \times \mathrm{P}$ & 10 & 100 & 103 & $1,1 \pm 0,3$ & 50,6 \\
\hline$(\mathrm{SS}) \times \mathrm{S}$ & 9 & 100 & 149 & $1,9 \pm 0,2$ & 48,5 \\
\hline $\mathrm{S} \times(\mathrm{SS})$ & 3 & 100 & 36 & $1,3 \pm 0,4$ & 31,4 \\
\hline$(R R) \times R$ & 9 & 100 & 88 & $1,2 \pm 0,4$ & 55,0 \\
\hline $\mathrm{R} \times(\mathrm{RR})$ & 8 & 100 & 55 & $0,8 \pm 0,3$ & 48,6 \\
\hline$(P P) \times P$ & 9 & 100 & 128 & $1,6 \pm 0,5$ & 50,0 \\
\hline $\mathrm{P} \times(\mathrm{PP})$ & 10 & 100 & 129 & $1,4 \pm 0,4$ & 54,5 \\
\hline
\end{tabular}

Observou-se oviposição nos cruzamentos e retrocruzamentos envolvendo as populações R e P (Tabela 6). No cruzamento de fêmeas R com machos P, 27,3\% das fêmeas ovipositaram. As fêmeas que não ovipositaram apresentavam endospermatóforos nas espermatecas, indicando a ocorrência de cópula e transferência de esperma. Neste cruzamento, a oviposição média diária foi muito inferior aos cruzamentos homogâmicos das populações $\mathrm{P}$ e $\mathrm{R}$, como resultado do reduzido número de fêmeas que ovipositaram. Devido ao reduzido número de descendentes fêmeas não foi realizado o retrocruzamento (RP)xR. No cruzamento inverso, 100\% das fêmeas ovipositaram, e a oviposição média diária foi próxima à obtida nos cruzamentos homogâmicos. 
Tabela 6. Resultados de cruzamentos e retrocruzamentos heterogâmicos, no período de 10 dias, de populações de Euseius citrifolius procedentes de Arroio do Meio-RS (R) e Petrolina-PE (P), a $25 \pm 1{ }^{\circ} \mathrm{C}, 70 \pm 5 \%$ de umidade relativa e $12 \mathrm{~h}$ de fotofase.

\begin{tabular}{|c|c|c|c|c|c|}
\hline 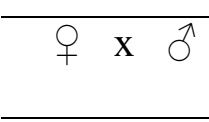 & $\mathrm{N}^{\mathrm{o}}$ casais & $\begin{array}{l}\text { \% Fêmeas } \\
\text { ovipositando }\end{array}$ & $\begin{array}{c}\text { Total de } \\
\text { ovos }\end{array}$ & $\begin{array}{c}\text { Ovos/q/dia } \\
( \pm \mathrm{EP})\end{array}$ & $\begin{array}{l}\text { Razão sexual } \\
\text { (\% fêmeas) }\end{array}$ \\
\hline $\mathrm{R} \times \mathrm{P}$ & 22 & 27,3 & 30 & $0,2 \pm 0,0$ & 30,8 \\
\hline$P \times R$ & 14 & 100 & 128 & $1,0 \pm 0,3$ & 42,2 \\
\hline $\mathrm{R} \times(\mathrm{RP})$ & 5 & 80,0 & 38 & $0,8 \pm 0,3$ & 61,1 \\
\hline $\mathrm{P} \times(\mathrm{RP})$ & 4 & 100 & 28 & $0,8 \pm 0,4$ & 35,7 \\
\hline (RP) $x \mathrm{P}$ & 7 & 71,4 & 34 & $0,5 \pm 0,2$ & 28,6 \\
\hline $\mathrm{P} \times(\mathrm{PR})$ & 6 & 100 & 43 & $0,8 \pm 0,1$ & 48,4 \\
\hline (PR) $x \mathrm{P}$ & 12 & 16,7 & 2 & $*$ & - \\
\hline $\mathrm{R} \times(\mathrm{PR})$ & 10 & 70,0 & 49 & $0,5 \pm 0,2$ & 39,4 \\
\hline$(P R) \times R$ & 10 & 20,0 & 2 & $*$ & - \\
\hline
\end{tabular}

* Menos de 0,1 ovo por fêmea por dia

EP : Erro Padrão da Média

Nos retrocruzamentos (PR)xP e (PR)xR, 16,7 e $20,0 \%$ das fêmeas ovipositaram, respectivamente. Entretanto, os poucos ovos obtidos eram deformados e inviáveis. Aparentemente as fêmeas (PR), resultantes do cruzamento de fêmeas $\mathrm{P} e$ machos R, eram estéreis já que no cruzamento de duas fêmeas (PR) com machos (PR) os ovos se apresentaram deformados e inviáveis. No retrocruzamento (RP)xP $71,4 \%$ das fêmeas ovipositaram e $23,5 \%$ dos ovos eram viáveis.

Observou-se oviposição nos cruzamentos e retrocruzamentos com as populações $\mathrm{P}$ e S. Nos cruzamentos envolvendo fêmeas $\mathrm{P}$ e machos $\mathrm{S}$ e vice-versa, 76,0 e 53,3\% das fêmeas, respectivamente, ovipositaram. As fềmeas que não ovipositaram apresentavam endospermatóforos nas espermatecas. A oviposição média diária foi de 0,6 e 0,5 ovos por fêmea, respectivamente (Tabela 7), inferior às respectivas médias dos cruzamentos homogâmicos. No retrocruzamento (PS)xP apenas 1 das 8 fêmeas testadas ovipositou, produzindo 2 ovos, ambos deformados e inviáveis. No retrocruzamento 
(PS)xS, 1 das 5 fêmeas testadas ovipositou, produzindo 1 ovo deformado e inviável. Uma fêmea (PS) cruzada com um macho (PS) não ovipositou, embora endospermatóforos pudessem ser vistos em suas espermatecas.

Tabela 7. Resultados de cruzamentos e retrocruzamentos heterogâmicos, no período de 10 dias, de populações de Euseius citrifolius procedentes de PetrolinaPE (P) e Campinas-SP (S), a $25 \pm 1{ }^{\circ} \mathrm{C}, 70 \pm 5 \%$ de umidade relativa e 12 $\mathrm{h}$ de fotofase.

\begin{tabular}{|c|c|c|c|c|c|}
\hline $9 \times 1$ & $\mathrm{~N}^{\mathrm{o}}$ casais & $\begin{array}{c}\text { \% Fêmeas } \\
\text { ovipositando }\end{array}$ & $\begin{array}{c}\text { Total de } \\
\text { ovos }\end{array}$ & $\begin{array}{c}\text { Ovos/Q/dia } \\
( \pm \mathrm{EP})\end{array}$ & $\begin{array}{c}\text { Razão sexual } \\
\text { (\% fêmeas) }\end{array}$ \\
\hline$P \times S$ & 25 & 76,0 & 139 & $0,6 \pm 0,1$ & 21,0 \\
\hline $\mathrm{S} \times \mathrm{P}$ & 15 & 53,3 & 55 & $0,5 \pm 0,1$ & 43,2 \\
\hline $\mathrm{S} \times(\mathrm{PS})$ & 9 & 22,2 & 9 & $0,1 \pm 0,0$ & 28,6 \\
\hline$(\mathrm{PS}) \times \mathrm{S}$ & 5 & 20,0 & 1 & $*$ & - \\
\hline $\mathrm{P} \times(\mathrm{PS})$ & 10 & 90,0 & 92 & $1,0 \pm 0,3$ & 51,0 \\
\hline$(\mathrm{PS}) \times \mathrm{P}$ & 8 & 12,5 & 2 & * & - \\
\hline $\mathrm{S} \times(\mathrm{SP})$ & 5 & 80,0 & 38 & $0,8 \pm 0,3$ & 45,4 \\
\hline$(\mathrm{SP}) \times \mathrm{S}$ & 3 & 100 & 12 & $0,5 \pm 0,3$ & 100 \\
\hline $\mathrm{P} \times(\mathrm{SP})$ & 8 & 87,5 & 93 & $1,2 \pm 0,4$ & 16,3 \\
\hline$(\mathrm{SP}) \times \mathrm{P}$ & 10 & 70,0 & 56 & $0,7 \pm 0,2$ & 87,0 \\
\hline
\end{tabular}

* Menos de 0,1 ovo por fêmea por dia EP : Erro Padrão da Média

Nos demais retrocruzamentos, acima de 69\% das fêmeas ovipositaram com exceção do retrocruzamento $\mathrm{Sx}(\mathrm{PS})$, em que apenas 22,2\% das fêmeas ovipositaram. Nos retrocruzamentos $\operatorname{Px}(\mathrm{PS})$ e $\operatorname{Sx}(\mathrm{SP})$ a oviposição média diária foi de 1,0 e 0,8 ovos por fêmea, respectivamente. A oviposição média resultante do cruzamento Px(PS) foi semelhante à obtida no cruzamento homogâmico PxP. A oviposição média do retrocruzamento $\mathrm{Sx}(\mathrm{SP})$ foi reduzida em comparação à obtida no cruzamento homogâmico SxS. 


\subsection{Discussão}

A necessidade da presença do macho para a ocorrência de oviposição de populações de E. citrifolius foi confirmada neste trabalho, sugerindo a possível necessidade de fecundação dos óvulos para que ocorra a oviposição. Resultados semelhantes haviam sido obtidos por Moraes \& McMurtry (1981). Isto significa que os resultados de cruzamentos em laboratório podem ser utilizados para inferir a ocorrência de acasalamento nos casos em que oviposição tenha sido verificada.

Os níveis de oviposição de E. citrifolius neste trabalho foram inferiores ao verificado por Furtado (1997), de 1,7 ovos por fêmea por dia, para uma população de Jaguariúna-SP alimentada com pólen de taboa. Jaguariúna é um município vizinho de Campinas, de onde foi coletada uma das populações utilizadas no presente estudo. Moraes \& McMurtry (1981) observaram para a mesma espécie uma oviposição média diária variando de 0,8 a 2,5 ovos por fêmea para valores definidos de temperaturas variando de $15{ }^{\circ} \mathrm{C}$ a $30{ }^{\circ} \mathrm{C}$, tendo como alimento uma combinação de ovos de Tetranychus pacificus McGregor e pólen de Malephora crocea (Jacq.). Moreira (1993) obteve a média de 1,5 ovos por fêmea por dia quando este predador foi alimentado com pólen de mamona (Ricinus communis L.). Tanto Moraes \& McMurtry (1981) quanto Moreira (1993) trabalharam com populações identificadas como E. citrifolius procedentes do Estado de São Paulo.

Os resultados deste trabalho mostram a possibilidade de fluxo gênico direto entre as populações de Arroio do Meio e Petrolina, e Campinas e Petrolina, indicando que para cada uma daquelas combinações as populações pertencem a uma mesma espécie. Deduz-se também a possibilidade de fluxo gênico entre as populações de Arroio do Meio e Campinas, já que os cruzamentos RxP e SxP, e vice-versa produziram progênie, inclusive parcialmente constituídas por fêmeas. Essa dedução é corroborada por resultados preliminares obtidos do cruzamento $\mathrm{RxS}$ e dos retrocruzamentos $\mathrm{Rx}(\mathrm{RS})$ e (RS)xS, verificando-se a produção de progênies constituídas de fêmeas e machos.

Estudos conduzidos com 3 espécies de Phytoseiidae demonstraram que a reprodução destes se dá através de um processo conhecido como pseudo-arrenotoquia 
(Hoy, 1979; Schulten, 1985). Por esse processo, as fêmeas são diplóides e os machos haplóides, em decorrência da eliminação de um conjunto de cromossomos durante o desenvolvimento do embrião. Como o conjunto de cromossomos eliminados é de origem paterna, assume-se que os machos apresentam material genético materno. $\mathrm{Na}$ verdade este aspecto continua sendo pesquisado; algumas evidências sugerem um certo nível de contribuição genética paterna na produção de machos haplóides no processo de pseudoarrenotoquia. Duas possibilidades são propostas para tanto. A primeira seria a incorporação do material genético paterno no embrião antes da eliminação do conjunto de cromossomos nos ovos que irão dar origem a machos, e a segunda seria que a perda do genoma paternal não é absoluta (Perrot-Minnot \& Navajas, 1995). O estudo recente conduzido por Perrot-Minnot et al. (2000) sugere que o material genético paternal presente nos descendentes machos da geração F1 de Neoseiulus californicus (McGregor) não é transmitido através do esperma para os descendentes de retrocruzamentos de fêmeas parentais com machos da geração F1.

Assumindo o padrão de reprodução por pseudo-arrenotoquia, a produção de progênie nos retrocruzamentos envolvendo os machos (RP), (PR), (PS) e (SP) e fêmeas das respectivas gerações maternas era esperada, a julgar pelos resultados dos cruzamentos RxP, PxR, PxS e SxP, respectivamente. Por outro lado, esperava-se também que a oviposição média diária no retrocruzamento $\mathrm{Sx}(\mathrm{SP})$ fosse semelhante à do cruzamento SxS, o que não ocorreu, sem uma causa aparente.

A compatibilidade reprodutiva entre as populações estudadas é entretanto apenas parcial, tendo em vista que alguns retrocruzamentos não produziram descendentes viáveis. Os resultados verificados nos retrocruzamentos envolvendo fêmeas (PR) e (PS) sugerem a esterilidade dessas fêmeas. Esta incompatibilidade seria classificada como um mecanismo pós-copulatório, caracterizado por uma esterilidade híbrida, que corresponde à incapacidade dos híbridos de produzirem um número normal de gametas viáveis (Mayr, 1977).

A incompatibilidade reprodutiva entre diferentes populações nem sempre é devida às suas características intrínsecas. Um fator extrínseco que tem sido comumente citado se refere a uma bactéria intracelular até agora encontrada em artrópodos e 
nematóide, conhecida como Wolbachia. Esta bactéria já foi reportada em espécies de tetraniquídeos e fitoseídeos (Geest et al., 2000; Werren, 1997). Werren (1997) citou que esta pode induzir incompatibilidade citoplasmática, unidirecional ou bidirecional. Aparentemente, nenhuma das formas se aplica diretamente aos resultados encontrados neste estudo, já que a incompatibilidade unidirecional tem sido observada quando o esperma de machos infectados fertiliza óvulos não infectados, com o cruzamento recíproco (machos não infectados e fêmeas infectadas) sendo compatível. A incompatibilidade bidirecional ocorre quando machos e fêmeas apresentam diferentes populações de Wolbachia, mutuamente incompatíveis. Se somente a população R estivesse infectada por Wolbachia, considerando-se a reduzida oviposição média diária obtida no cruzamento RxP, seria esperada a incompatibilidade no cruzamento PxR e no retrocruzamento $\operatorname{Px}(\mathrm{RP})$, o que não ocorreu neste estudo. Três análises ao nível molecular foram realizadas na Universidade de Amsterdam para a detecção desta bactéria nas populações de E. citrifolius utilizadas neste estudo, com resultados não conclusivos.

Outras infecções presentes em ácaros causadas por bactérias e relatadas na literatura, são descritas como microrganismos intracelulares localizados freqüentemente em tecidos reprodutivos, mas sem conhecimento sobre a atuação das mesmas (Geest et al., 2000).

Assim, a aparente incompatibilidade reprodutiva nos retrocruzamentos envolvendo fêmeas híbridas cujas mães eram de Petrolina e machos das populações parentais pode ser devida a características intrínsecas representadas por diferenças no genoma das populações, em função da distância geográfica entre estas populações e a completa ausência de troca gênica entre estas na natureza. 


\subsection{Conclusões}

- Existe uma incompatibilidade reprodutiva parcial entre a população de Petrolina e as populações de Arroio do Meio e Campinas.

- As populações identificadas como E. citrifolius procedentes de Arroio do Meio-RS, Campinas-SP e Petrolina-PE pertencem a uma mesma espécie, de vez que o fluxo gênico ocorre entre as populações de Campinas e Petrolina, e de Arroio do Meio e Petrolina. 


\section{COMPATIBILIDADE REPRODUTIVA ENTRE POPULAÇÕES IDENTIFICADAS COMO Euseius concordis (ACARI, PHYTOSEIIDAE)}

\section{RESUMO}

O objetivo deste estudo foi avaliar a compatibilidade reprodutiva entre populações de fitoseídeos de diferentes regiões do Brasil identificadas como Euseius concordis (Chant), para comprovação de que pertencem a uma mesma espécie. Este estudo complementa o trabalho realizado no capítulo 3. As populações foram coletadas de Passiflora edulis Sims. f. favicarpa Deg. em Arroio do Meio-RS, Manihot esculenta (Crantz) em Jaguariúna-SP, Hevea brasiliensis Muell. Arg. em Pontes e Lacerda-MT, Terminalia catappa L. em Petrolina-PE e Coffea arabica L. em Viçosa-MG. Cruzamentos e retrocruzamentos homogâmicos e heterogâmicos foram conduzidos para observação da reprodução durante um período de 10 dias. Os níveis de oviposição nos cruzamentos homogâmicos foram geralmente maiores que nos cruzamentos heterogâmicos. Cruzamentos e retrocruzamentos heterogâmicos envolvendo fêmeas de Petrolina não produziram ovos, embora tenha sido verificada a presença de endospermatóforos nas espermatecas daquelas fêmeas. Nos cruzamentos heterogâmicos envolvendo machos de Petrolina, a oviposição foi reduzida e somente machos foram produzidos. No cruzamento com fêmeas de Pontes e Lacerda e machos de Jaguariúna e vice-versa, as progênies foram constituídas somente de machos. Entretanto, o fluxo gênico entre estas populações seria possível indiretamente, através de cruzamentos de cada uma destas populações com ácaros de Arroio do Meio. Os resultados obtidos 
indicaram que as populações de Arroio do Meio, Pontes e Lacerda, Jaguariúna e Viçosa pertencem à mesma espécie. Não foi possível comprovar que a população de Petrolina pertence à mesma espécie das demais populações testadas.

\section{REPRODUCTIVE COMPATIBILITY BETWEEN POPULATIONS IDENTIFIED AS Euseius concordis (ACARI, PHYTOSEIIDAE)}

\section{SUMMARY}

The objective of this study was to evaluate the reproductive compatibility between populations of phytoseiid mites from different regions of Brazil identified as Euseius concordis (Chant), to determine their con-specificity. The study complements the work reported in chapter 3. Populations were collected from Passiflora edulis Sims. f. flavicarpa Deg. in Arroio do Meio-RS, Manihot esculenta (Crantz) in Jaguariúna-SP, Hevea brasiliensis Muell. Arg. in Pontes e Lacerda-MT, Terminalia catappa L. in Petrolina-PE and Coffea arabica L. in Viçosa-MG. Homogamic and heterogamic crosses and backcrosses were conducted to determine the ovipostion rate within a period of 10 days. Levels of oviposition in homogamic crosses were generally higher than in heterogamic crosses. No eggs were produced in heterogamic crosses and backcrosses involving females from Petrolina, although endospermatophores were visible within the spermathecae of those females. In heterogamic crosses involving males from Petrolina oviposition was reduced and only males were produced. Crosses of females from Pontes e Lacerda and males from Jaguariúna and vice-versa produced only male progeny. However, gene flow between those population could be possible indirectly, through crossings between mites from each of those populations with mites from Arroio do 
Meio. The results indicated that the populations from Arroio do Meio, Jaguariúna, Pontes e Lacerda and Viçosa belong to a same species. It was not possible to determine that the population from Petrolina belongs to the same species.

\subsection{Introdução}

Ácaros da família Phytoseiidae constituem um grupo eficiente de predadores de ácaros fitófagos. Os fitoseídeos vêm sendo empregados no controle biológico de ácaro fitófagos considerados pragas importantes em vários cultivos, com relatos de sucesso em culturas como citros, mandioca, maçã, milho e morango (International Institute of Tropical Agriculture, 1995; McMurtry, 1982; McMurtry et al., 1978; Moraes, 1991; Pickett \& Gilstrap, 1986).

A correta identificação dos agentes de controle biológico a serem introduzidos em uma nova área é fundamental, já que identificações imprecisas podem resultar em insucessos (Moraes, 1987). A taxonomia de ácaros fitoseídeos é baseada quase que totalmente na avaliação de características morfológicas, que muitas vezes não são suficientes para permitir a distinção entre espécies muito semelhantes.,

A constatação de Lofego (1998) de que existem variações das dimensões de algumas estruturas em exemplares de Euseius concordis (Chant) procedentes de várias regiões levaram-no a sugerir que os exemplares por ele analisados poderiam pertencer a mais de uma espécie, muito próximas entre si. Pequenas diferenças morfológicas e resultados de cruzamentos obtidos por Furtado (1997) entre populações de E. concordis procedentes de Jaguariúna-SP e Petrolina-PE indicaram a possibilidade de que se tratassem de 2 espécies morfologicamente muito próximas, mas distintas do ponto de vista biológico. Isto levou aquela autora a sugerir que estudos adicionais de cruzamentos

envolvendo também populações geograficamente intermediárias entre aqueles 2 extremos poderiam elucidar este aspecto. A caracterização morfológica de populações 
de E. concordis procedentes de regiões distantes entre si, realizada no capítulo 3, mostrou a sobreposição entre as amplitudes de variação da maioria das estruturas medidas, embora algumas destas estruturas se mostrassem distintamente menores na população de Jaguariúna que na população de Petrolina. Conseqüentemente, não foi possível estabelecer com segurança uma diferenciação morfológica entre todas as populações, apesar da ocorrência de variações nas dimensões de algumas estruturas.

Estudos de cruzamentos e, mais recentemente, de caracterização molecular têm sido realizados com populações de ácaros em complemento à caracterização morfológica, para esclarecer certas dúvidas quando do estudo de populações consideradas da mesma espécie e provenientes de várias áreas geográficas (Abou-Setta et al., 1991; Croft, 1970; Hoying \& Croft, 1977; McMurtry, 1980; Navajas et al., 1992, 1994 e 1997).

Este trabalho foi realizado para verificar a compatibilidade reprodutiva entre algumas populações identificadas como E. concordis, coletadas em várias regiões do país, para a comprovação de que pertencem a uma mesma espécie, em complementação ao trabalho relatado no capítulo 3 .

\subsection{Material e Métodos}

Colônias de E. concordis foram estabelecidas a partir de espécimes coletados de Passiflora edulis Sims. f. flavicarpa Deg. em Arroio do Meio-RS (R), Manihot esculenta (Crantz) em Jaguariúna-SP (S), Hevea brasiliensis Muell. Arg. em Pontes e Lacerda-MT (M), Terminalia catappa L. em Petrolina-PE (P) e Coffea arabica L. em Viçosa-MG (V). A localização dos pontos de coleta, assim como o número de indivíduos para o início das colônias foram apresentados no capítulo 3 .

As colônias foram mantidas no interior de bandejas plásticas $(20 \times 15 \times 5 \mathrm{~cm}) \mathrm{com}$ tampa perfurada para promover a aeração, sobre placas de resina (Paviflex ${ }^{\circledR}$ ) de cor preta, colocadas sobre um pedaço de espuma de náilon umedecida diariamente com água destilada, semelhantemente ao que foi descrito por McMurtry \& Scriven (1965). 
As criações foram mantidas nas mesmas condições de alimentação, temperatura, umidade relativa e fotofase descritas no capítulo 4.

Cruzamentos: Para o início dos testes de cruzamentos, aproximadamente 100 fêmeas de cada população foram transferidas para unidades semelhantes às utilizadas para a manutenção de colônias descritas no capítulo 4, contendo uma folha de feijão-de-porco (Canavalia ensiformis DC.) com o pecíolo inserido sob uma tira do algodão umedecido ( $2 \mathrm{~cm}$ de largura) que cobria as bordas da placa de resina. Como alimento, foi utilizado pólen de taboa (Typha angustifolia L.) coletado e mantido nas mesmas condições citadas no capítulo anterior. Os ovos postos sobre a folha de feijão dentro de um período de 12 horas foram retirados para utilização nos testes, conduzidos como também descrito no capítulo 4. Foram formados pelo menos 10 casais homogâmicos e 10 casais heterogâmicos, correspondentes às possíveis combinações das populações, exceto a população de Viçosa, que foi cruzada apenas com as populações de Jaguariúna e Petrolina.

Observação de endospermatóforos: Para os cruzamentos em que nenhuma progênie foi obtida, realizou-se uma observação complementar para se constatar se a aparente incompatibilidade se devia a processos que ocorriam antes ou após o acasalamento. Foram formados 10 casais para cada combinação. Como controle, foram formados 5 casais homogâmicos da população de Petrolina. Quarenta e oito horas após a formação dos casais, as fêmeas foram montadas em meio de Hoyer e observadas em microscópio para verificação da presença de endospermatóforos no interior de suas espermatecas. Não foram consideradas na avaliação as poucas fêmeas que morreram naquele período.

\subsection{Resultados}

Fêmeas virgens das diferentes populações não ovipositaram durante o período de observação. 
Acima de $85 \%$ das fêmeas dos cruzamentos e retrocruzamentos homogâmicos ovipositaram, e a oviposição média diária variou de 0,6 a 1,9 e de 0,8 a 1,6, respectivamente. A proporção média de fêmeas variou de 38,2 a 54,7\% nos cruzamentos e de 46 a 58,8\% nos retrocruzamentos (Tabela 8 ).

Tabela 8. Resultados de cruzamentos e retrocruzamentos homogâmicos, no período de 10 dias, de populações de Euseius concordis procedentes de Jaguariúna-SP (S), Arroio do Meio-RS (R), Petrolina-PE (P), Pontes e Lacerda-MT (M) e Viçosa-MG (V) a $25 \pm 1{ }^{\circ} \mathrm{C}, 70 \pm 5 \%$ de umidade relativa e $12 \mathrm{~h}$ de fotofase.

\begin{tabular}{|c|c|c|c|c|c|}
\hline q $\mathrm{x} \quad 0^{\top}$ & $\mathrm{N}^{0}$ casais & $\begin{array}{c}\text { \% Fêmeas } \\
\text { ovipositando }\end{array}$ & $\begin{array}{c}\text { Total de } \\
\text { ovos }\end{array}$ & $\begin{array}{c}\text { Ovos/Q/ } / \text { dia } \\
( \pm \text { EP) }\end{array}$ & $\begin{array}{c}\text { Razão sexual } \\
\text { (\% fêmeas) }\end{array}$ \\
\hline$S \times S$ & 9 & 100 & 158 & $1,9 \pm 0,2$ & 51,6 \\
\hline $\mathrm{R} \times \mathrm{R}$ & 8 & 100 & 128 & $1,7 \pm 0,2$ & 50,0 \\
\hline $\mathrm{P} \times \mathrm{P}$ & 10 & 90,0 & 116 & $1,2 \pm 0,2$ & 54,7 \\
\hline $\mathrm{M} \times \mathrm{M}$ & 10 & 90,0 & 57 & $0,6 \pm 0,1$ & 47,6 \\
\hline V x V & 10 & 100 & 51 & $0,6 \pm 0,1$ & 38,2 \\
\hline$(\mathrm{SS}) \times \mathrm{S}$ & 9 & 100 & 127 & $1,6 \pm 0,2$ & 53,9 \\
\hline $\mathrm{S} \times(\mathrm{SS})$ & 9 & 100 & 124 & $1,3 \pm 0,2$ & 57,9 \\
\hline$(R R) \times R$ & 6 & 100 & 81 & $1,4 \pm 0,3$ & 46,0 \\
\hline $\mathrm{R} \times(\mathrm{RR})$ & 9 & 100 & 92 & $1,1 \pm 0,1$ & 48,1 \\
\hline$(\mathrm{PP}) \times \mathrm{P}$ & 9 & 88,9 & 136 & $1,5 \pm 0,5$ & 57,3 \\
\hline $\mathrm{P} \times(\mathrm{PP})$ & 9 & 100 & 129 & $1,5 \pm 0,5$ & 58,8 \\
\hline$(\mathrm{MM}) \times \mathrm{M}$ & 9 & 100 & 112 & $1,3 \pm 0,2$ & 54,9 \\
\hline $\mathrm{M} \times(\mathrm{MM})$ & 7 & 100 & 50 & $0,8 \pm 0,1$ & 54,5 \\
\hline$(V V) \times V$ & 9 & 100 & 81 & $1,2 \pm 0,2$ & 46,6 \\
\hline $\mathrm{V} \times(\mathrm{VV})$ & 7 & 85,7 & 53 & $0,9 \pm 0,2$ & 47,8 \\
\hline
\end{tabular}

EP : Erro Padrão da Média

Nos cruzamentos envolvendo fêmeas $\mathrm{S}$ e machos $\mathrm{R}$ e vice-versa, a oviposição média diária foi de 1,1 e 1,3 ovos por fêmea, respectivamente (Tabela 9), valores inferiores aos cruzamentos homogâmicos dessas populações. A proporção de fêmeas obtidas foi muito diferente dos cruzamentos homogâmicos correspondentes. Do total de ovos obtidos do cruzamento $\mathrm{SxR}, 40$ indivíduos chegaram à fase adulta, sendo todos 
machos. No cruzamento recíproco e em todos os retrocruzamentos ambos os sexos foram obtidos, embora em 2 casos ( $\mathrm{SxRS}$ e RSxS) as proporções das fêmeas obtidas tenham sido baixa.

Tabela 9. Resultados de cruzamentos e retrocruzamentos heterogâmicos, no período de 10 dias, de populações de Euseius concordis procedentes de Jaguariúna-SP (S) e Arroio do Meio-RS (R), a $25 \pm 1{ }^{\circ} \mathrm{C}, 70 \pm 5 \%$ de umidade relativa e $12 \mathrm{~h}$ de fotofase.

\begin{tabular}{|c|c|c|c|c|c|}
\hline$q \times 0$ & $\mathrm{~N}^{0}$ casais & $\begin{array}{c}\text { \% Fêmeas } \\
\text { ovipositando }\end{array}$ & Total de ovos & $\begin{array}{l}\text { Ovos/P/dia } \\
( \pm \mathrm{EP})\end{array}$ & $\begin{array}{c}\text { Razão sexual } \\
\text { (\% fêmeas) }\end{array}$ \\
\hline $\mathrm{S} \times \mathrm{R}$ & 7 & 85,7 & 52 & $1,1 \pm 0,3$ & 0 \\
\hline $\mathrm{R} \times \mathrm{S}$ & 10 & 100 & 130 & $1,3 \pm 0,2$ & 31,7 \\
\hline $\mathrm{S} \times(\mathrm{SR})$ & 9 & 100 & 140 & $1,6 \pm 0,2$ & 44,8 \\
\hline $\mathrm{R} \times(\mathrm{SR})$ & 10 & 100 & 121 & $1,2 \pm 0,1$ & 48,4 \\
\hline $\mathrm{S} \times(\mathrm{RS})$ & 9 & 88,9 & 75 & $0,9 \pm 0,2$ & 25,0 \\
\hline R x (RS) & 8 & 100 & 113 & $1,5 \pm 0,2$ & 56,1 \\
\hline$(\mathrm{RS}) \times \mathrm{S}$ & 4 & 100 & 37 & $1,0 \pm 0,1$ & 10,0 \\
\hline$(\mathrm{RS}) \times \mathrm{R}$ & 5 & 100 & 78 & $1,6 \pm 0,2$ & 87,5 \\
\hline
\end{tabular}

EP : Erro Padrão da Média

Padrão de resposta aproximadamente uniforme foi obtido em todos os cruzamentos heterogâmicos envolvendo a população de Petrolina. Nenhuma oviposição foi obtida nos cruzamentos e retrocruzamentos em que a fêmea era da população $P$ (Tabela 10). Nos retrocruzamentos em que as fêmeas eram $\mathrm{R}, \mathrm{S}, \mathrm{M}$ e V, pelo menos $85,7 \%$ destas ovipositaram, os índices diários de oviposição foram aproximadamente os mesmos ou inferiores aos das populações maternas, e a proporção de descendentes fêmeas foi aproximadamente a mesma das populações estudadas.

Alguma oviposição foi obtida quando o macho era da população de Petrolina, mas em todos os cruzamentos a descendência foi composta apenas por machos (Tabela $10)$. 
No cruzamento PxR, 3 casais foram observados em posição de cópula por ocasião das avaliações. Apesar de todas as fêmeas ovipositarem no cruzamento RxP, a oviposição média diária correspondeu a menos de $40 \%$ daquela observada nos cruzamentos homogâmicos correspondentes (Tabela 10). Além do mais, 30\% dos ovos postos por aquelas fêmeas estavam deformados e inviáveis. Dos ovos remanescentes, 20 adultos foram obtidos, sendo todos machos.

Tabela 10. Resultados de cruzamentos e retrocruzamentos heterogâmicos, no período de 10 dias, de populações de Euseius concordis procedentes de PetrolinaPE (P), Arroio do Meio-RS (R), Jaguariúna-SP (S), Pontes e Lacerda-MT (M) e Viçosa-MG (V), a $25 \pm 1{ }^{\circ} \mathrm{C}, 70 \pm 5 \%$ de umidade relativa e $12 \mathrm{~h}$ de fotofase.

\begin{tabular}{|c|c|c|c|c|c|}
\hline$q \times 0^{\pi}$ & $\mathrm{N}^{0}$ casais & $\begin{array}{c}\text { \% Fêmeas } \\
\text { ovipositando }\end{array}$ & Total de ovos & $\begin{array}{c}\text { Ovos/P/dia } \\
( \pm \mathrm{EP})\end{array}$ & $\begin{array}{c}\text { Razão sexual } \\
\text { (\% fêmeas) }\end{array}$ \\
\hline$P \times R$ & 9 & 0 & - & - & - \\
\hline $\mathrm{R} \times \mathrm{P}$ & 10 & 100 & $40^{*}$ & $0,4 \pm 0,1$ & 0 \\
\hline $\mathrm{R} \times(\mathrm{RP})$ & 7 & 85,7 & 48 & $0,7 \pm 0,1$ & 55,9 \\
\hline $\mathrm{P} \times(\mathrm{RP})$ & 10 & 0 & - & - & - \\
\hline $\mathrm{P} \times \mathrm{S}$ & 9 & 0 & - & - & - \\
\hline $\mathrm{S} \times \mathrm{P}$ & 9 & 66,7 & 15 & $0,2 \pm 0,1$ & 0 \\
\hline $\mathrm{S} \times(\mathrm{SP})$ & 5 & 100 & 66 & $1,3 \pm 0,6$ & 47,6 \\
\hline $\mathrm{P} \times(\mathrm{SP})$ & 6 & 0 & - & - & - \\
\hline $\mathrm{P} \times \mathrm{M}$ & 8 & 0 & - & - & - \\
\hline $\mathrm{M} \times \mathrm{P}$ & 18 & 44,4 & 10 & $0,1 \pm 0,1$ & 0 \\
\hline $\mathrm{P} \times(\mathrm{MP})$ & 4 & 0 & - & - & - \\
\hline$P \times V$ & 7 & 0 & - & - & - \\
\hline $\mathrm{V} \times \mathrm{P}$ & 18 & 44,4 & 24 & $0,2 \pm 0,1$ & 0 \\
\hline $\mathrm{V} \times(\mathrm{VP})$ & 5 & 100 & 30 & $0,8 \pm 0,2$ & 54,0 \\
\hline P x (VP) & 6 & 0 & - & - & - \\
\hline
\end{tabular}

* 12 ovos deformados EP : Erro Padrão da Média 
No cruzamento SxP $66,7 \%$ das fêmeas ovipositaram e a oviposição média diária foi menor que $20 \%$ daquela dos cruzamentos homogâmicos correspondentes. Um casal no cruzamento PxS e 3 casais no retrocruzamento $\operatorname{Px}(\mathrm{SP})$ foram observados em posição de cópula durante as observações.

No cruzamento MxP apenas 44,4\% das fêmeas ovipositaram e a oviposição média diária também foi menor que $20 \%$ daquela dos cruzamentos homogâmicos correspondentes. Dois dos 10 ovos obtidos estavam deformados e inviáveis. Devido ao reduzido número de descendentes, não foi realizado o retrocruzamento $\mathrm{Mx}(\mathrm{MP})$.

No cruzamento VxP, apenas 44,4\% das fêmeas ovipositaram e a oviposição média diária foi também menor que $20 \%$ daquela dos cruzamentos homogâmicos correspondentes (Tabela 10).

Observou-se oviposição em todos os cruzamentos e retrocruzamentos envolvendo as populações $\mathrm{M}$ e $\mathrm{R}$, com a produção média diária de 0,6 a 1,5 ovos por fêmea e a proporção de descendentes fêmeas variando de 44,4 a 58,6\% (Tabela 11).

Tabela 11. Resultados de cruzamentos e retrocruzamentos heterogâmicos, no período de 10 dias, de populações de Euseius concordis procedentes de Pontes e Lacerda-MT (M) e Arroio do Meio-RS (R), a $25 \pm 1{ }^{\circ} \mathrm{C}, 70 \pm 5 \%$ de umidade relativa e $12 \mathrm{~h}$ de fotofase.

\begin{tabular}{|c|c|c|c|c|c|}
\hline$q \times 0$ & $\mathrm{~N}^{\mathrm{o}}$ casais & $\begin{array}{c}\text { \% Fêmeas } \\
\text { ovipositando }\end{array}$ & Total de ovos & $\begin{array}{c}\text { Ovos/P/dia } \\
( \pm \text { EP })\end{array}$ & $\begin{array}{c}\text { Razão sexual } \\
\text { (\% fêmeas) }\end{array}$ \\
\hline$M \times R$ & 8 & 100 & 42 & $0,6 \pm 0,1$ & 45,4 \\
\hline $\mathrm{R} \times \mathrm{M}$ & 9 & 88,9 & 78 & $1,0 \pm 0,2$ & 44,4 \\
\hline$(\mathrm{MR}) \times \mathrm{R}$ & 11 & 100 & 87 & $1,0 \pm 0,1$ & 51,6 \\
\hline R x (MR) & 7 & 100 & 72 & $1,1 \pm 0,2$ & 58,2 \\
\hline$(\mathrm{MR}) \times \mathrm{M}$ & 4 & 100 & 36 & $0,9 \pm 0,2$ & 48,1 \\
\hline M x (MR) & 5 & 100 & 45 & $1,0 \pm 0,3$ & 47,0 \\
\hline$(R M) \times R$ & 7 & 85,7 & 49 & $0,7 \pm 0,2$ & 48,5 \\
\hline $\mathrm{R} x(\mathrm{RM})$ & 9 & 100 & 91 & $1,1 \pm 0,1$ & 58,6 \\
\hline$(\mathrm{RM}) \times \mathrm{M}$ & 8 & 100 & 103 & $1,5 \pm 0,1$ & 45,9 \\
\hline M x (RM) & 4 & 100 & 21 & $0,7 \pm 0,2$ & 46,7 \\
\hline
\end{tabular}

EP : Erro Padrão da Média 
No cruzamento MxS 100\% das fêmeas ovipositaram, a oviposição média diária foi de 0,6 ovos por fêmea, ou seja, a mesma obtida para a população M (Tabela 12). Metade dos ovos produzidos eram viáveis, mas geraram apenas machos. O restante dos ovos produzidos eram inviáveis. Neste caso, 4 a 5 dias após a oviposição, uma pequena mancha avermelhada apareceu no interior de cada ovo. Estes foram montados em meio de Hoyer, observando-se larvas totalmente formadas em seu interior. Apenas um dos ovos observados estava deformado e não apresentava larva visível. No cruzamento SxM $66,7 \%$ das fêmeas ovipositaram, a oviposição média diária foi de 0,5 ovos por fêmea, ou seja, aproximadamente a mesma obtida para a população M. Cerca de $77 \%$ dos ovos produzidos eram viáveis, mas geraram apenas machos.

Tabela 12. Resultados de cruzamentos e retrocruzamentos heterogâmicos, no período de 10 dias, de populações de Euseius concordis procedentes de Pontes e Lacerda-MT (M) e Jaguariúna-SP (S), a $25 \pm 1^{\circ} \mathrm{C}, 70 \pm 5 \%$ de umidade relativa e $12 \mathrm{~h}$ de fotofase.

\begin{tabular}{lccccc}
\hline \multicolumn{1}{c}{$+\times 0^{\wedge}$} & $\mathrm{N}^{0}$ casais & $\begin{array}{c}\text { \% Fêmeas } \\
\text { ovipositando }\end{array}$ & Total de ovos & $\begin{array}{c}\text { Ovos/q /dia } \\
( \pm \text { EP })\end{array}$ & $\begin{array}{c}\text { Razão sexual } \\
(\% \text { fêmeas })\end{array}$ \\
\hline M x S & 7 & 100 & 34 & $0,6 \pm 0,1$ & 0 \\
S x M & 9 & 66,7 & 31 & $0,5 \pm 0,1$ & 0 \\
M x(MS) & 5 & 80,0 & 30 & $0,7 \pm 0,3$ & 51,9 \\
S x (MS) & 6 & 66,7 & 23 & $0,4 \pm 0,2$ & 0 \\
M x (SM) & 10 & 100 & 73 & $0,8 \pm 0,1$ & 0 \\
S x (SM) & 6 & 100 & 67 & $1,1 \pm 0,2$ & 33,3 \\
& & & & & \\
\hline
\end{tabular}

EP: Erro Padrão da Média

No retrocruzamento $\mathrm{Mx}(\mathrm{MS}), 80 \%$ das fêmeas ovipositaram, a oviposição média diária foi de 0,7 ovos por fêmea, valor semelhante ao obtido no cruzamento homogâmico MxM, e 51,9\% dos adultos obtidos eram fêmeas. No retrocruzamento 
$\mathrm{Sx}(\mathrm{SM})$, todas as fêmeas ovipositaram, a oviposição média diária foi de 1,1 ovos por fêmea, valor inferior ao obtido no cruzamento homogâmico SxS, e 33,3\% dos adultos obtidos eram fêmeas.

Os resultados dos retrocruzamentos $\mathrm{Sx}(\mathrm{MS})$ e $\mathrm{Mx}(\mathrm{SM})$ foram semelhantes aos obtidos nos cruzamentos $\mathrm{SxM}$ e $\mathrm{MxS}$ no que se refere à oviposição média diária e ao fato de apenas machos terem sido obtidos. No retrocruzamento $\mathrm{Mx}(\mathrm{SM})$ 43,8\% dos indivíduos chegaram ao estádio adulto. Da mesma forma que para o cruzamento MxS uma considerável proporção dos ovos eram inviáveis (24,7\%), e larvas formadas podiam ser vistas em seu interior; 2 ovos deformados e sem larvas em seu interior foram obtidos.

Nos cruzamentos e retrocruzamentos com populações de $\mathrm{V}$ e $\mathrm{S}$ ocorreu oviposição e a subseqüente geração de fêmeas e machos, com exceção do cruzamento $\mathrm{SxV}$ e do retrocruzamento $\mathrm{Sx}(\mathrm{VS})$, em que a progênie foi constituída somente por machos (Tabela 13). A oviposição média diária variou de 0,5 a 1,3 e a proporção média de fêmeas variou de 0 a $66,7 \%$. No cruzamento $\mathrm{VxS}, 2$ ovos encontravam-se deformados e de 10 ovos aparentemente normais não ocorreu a eclosão de larvas, embora estas pudessem ser vistas em seu interior. O restante dos ovos, entretanto, produziram descendentes viáveis de ambos os sexos. O mesmo foi verificado no retrocruzamento (VS)xS, em que 18,9\% dos ovos estavam deformados e além destes, $34 \%$ dos ovos foram inviáveis, aparentemente de tamanho inferior aos demais, embora larvas também pudessem ser vistas em seu interior. 
Tabela 13. Resultados de cruzamentos e retrocruzamentos heterogâmicos, no período de 10 dias, de populações de Euseius concordis procedentes de ViçosaMG (V) e Jaguariúna-SP (S), a $25 \pm 1{ }^{\circ} \mathrm{C}, 70 \pm 5 \%$ de umidade relativa e 12 $\mathrm{h}$ de fotofase.

\begin{tabular}{lccccc}
\hline \multicolumn{1}{c}{$+\mathrm{N}^{\mathrm{o}}$ casais } & $\begin{array}{c}\text { \% Fêmeas } \\
\text { ovipositando }\end{array}$ & Total de ovos & $\begin{array}{c}\text { Ovos/ } / \text { dia } \\
( \pm \text { EP })\end{array}$ & $\begin{array}{c}\text { Razão sexual } \\
(\% \text { fêmeas })\end{array}$ \\
\hline V x S & 9 & 88,9 & 80 & $0,8 \pm 0,1$ & 30,6 \\
S x V & 12 & 75,0 & 58 & $0,5 \pm 0,1$ & 0 \\
& & & & & \\
V x (VS) & 9 & 88,9 & 68 & $0,9 \pm 0,2$ & 39,2 \\
S x (VS) & 9 & 77,8 & 42 & $0,5 \pm 0,2$ & 0 \\
(VS) x V & 4 & 75,0 & 21 & $0,6 \pm 0,2$ & 66,7 \\
(VS) x S & 8 & 100 & 89 & $1,3 \pm 0,2$ & 46,7 \\
S x (SV) & 7 & 100 & 50 & $0,9 \pm 0,1$ & 45,2 \\
V x (SV) & 9 & 88,9 & 41 & $0,6 \pm 0,1$ & 26,1 \\
& & & & & \\
\hline
\end{tabular}

EP: Erro Padrão da Média

\section{Observação de endospermatóforos}

Com exceção do cruzamento $\mathrm{PxV}$, foi verificada a presença de endospermatóforos no interior das espermatecas das fêmeas, indicando que acasalamento e inseminação ocorreram (Tabela 14). No cruzamento homogâmico PxP, 4 das 5 da fêmeas observadas apresentavam endospermatóforos, com uma média de 0,8 endospermatóforos por espermateca. Nos cruzamentos PxR, PxS e PxM, 77,8, 44,4 e $75,0 \%$ das fêmeas apresentavam endospermatóforos, com médias de 0,4, 1,2 e 1,0 endospermatóforos por espermateca, respectivamente. Embora endospermatóforos não tenham sido observados neste estudo no cruzamento $\mathrm{PxV}$, estes foram observados em 2 de 5 fêmeas analisadas ao final do décimo dia do período de observação no estudo citado anteriormente. 
Tabela 14. Número médio de endospermatóforos por espermateca, em fêmeas de Euseius concordis de cruzamentos homogâmicos e heterogâmicos, 48 horas após permanência com machos. Populações procedentes de Arroio do Meio-RS (R), Jaguariúna-SP (S), Petrolina-PE (P), Pontes e Lacerda-MT (M) e Viçosa-MG (V).

\begin{tabular}{|c|c|c|c|}
\hline \multirow[b]{2}{*}{$\begin{array}{c}\text { Cruzamentos } \\
+9 \mathrm{x} \delta\end{array}$} & \multirow[b]{2}{*}{ Fêmeas (n) } & \multicolumn{2}{|c|}{$\mathrm{N}^{\mathrm{o}}$ de Endospermatóforos } \\
\hline & & Total & $\begin{array}{l}\text { Por espermateca } \\
\text { (min-max) }\end{array}$ \\
\hline $\mathrm{PxP}^{1}$ & 5 & 5 & $0,8(0-2)$ \\
\hline PxR & 9 & 7 & $0,4(0-2)$ \\
\hline PxS & 10 & 24 & $1,2(0-4)$ \\
\hline PxM & 8 & 16 & $1,0(0-3)$ \\
\hline $\mathrm{PxV}$ & 10 & 0 & 0 \\
\hline
\end{tabular}

${ }^{1}$ Fêmeas com ovos visíveis e/ou ovipositando

\subsection{Discussão}

A necessidade da presença do macho para a ocorrência de oviposição nas populações de E. concordis foi confirmada neste trabalho, já que fêmeas isoladas dos machos não produziram ovos. Resultados semelhantes foram obtidos por Furtado (1997) para populações procedentes de Jaguariúna-SP e Petrolina-PE. Isto significa que os resultados de cruzamentos em laboratório podem ser utilizados para inferir a ocorrência de acasalamento nos casos em que a oviposição tenha sido verificada. Os resultados dos cruzamentos obtidos neste estudo mostraram que a inseminação de fêmeas ocorreu em todos os cruzamentos e retrocruzamentos. Considerando-se que E. concordis se reproduz através do processo de pseudo-arrenotoquia, conclui-se que a fecundação dos óvulos também se deu em todos os cruzamentos, exceto aqueles envolvendo fêmeas de Petrolina e machos de outras procedências, de vez que houve oviposição em todos aqueles casos. A ocorrência de pseudo-arrenotoquia em E. concordis, semelhantemente 
ao que tem sido verificado para outras espécies de fitoseídeos (Hoy, 1979; Schulten, 1985), foi sugerida pelos resultados das avaliações morfológicas dos descendentes de cruzamentos entre distintas populações (Capítulo 3).

Através dos cruzamentos e retrocruzamento homogâmicos pode-se estabelecer a taxa média de oviposição para cada população no período de 10 dias. Os níveis de oviposição neste trabalho encontram-se próximos aos citados por Furtado (1997), com relação às populações de E. concordis de Jaguariúna-SP e Petrolina-PE. Os valores verificados neste trabalho para as proporções médias de fêmeas em cada progênie resultantes dos cruzamentos homogâmicos (47,6 a 54,7\%), com exceção da população de Viçosa (38,2\%), encontram-se entre os citados por Sabelis (1985) para 30 espécies de fitoseídeos (40 a 85\%).

Os resultados deste trabalho indicam que populações identificadas como $E$. concordis procedentes de Arroio do Meio, Jaguariúna, Pontes e Lacerda e Viçosa pertencem a uma mesma espécie. Verifica-se a possibilidade de ocorrência de fluxo gênico direto entre a população de Arroio do Meio e as populações de Pontes e Lacerda ou Jaguariúna. Incompatibilidade parcial aparentemente ocorre entre as populações de Jaguariúna e Viçosa, a julgar pela ocorrência de alguns ovos inviáveis no cruzamento $\mathrm{VxS}$ e retrocruzamento (VS) xS, e a produção somente de machos no cruzamento $\mathrm{SxV}$ e retrocruzamento $\mathrm{Sx}(\mathrm{VS})$.

Os resultados indicam também que apenas machos são obtidos nos cruzamentos entre as populações S e M. A compatibilidade verificada em 2 (MxMS e SxSM) dos 4 retrocruzamentos era esperada, tendo em vista que a constituição genética dos machos é basicamente a mesma de suas mães no processo de reprodução por pseudoarrenotoquia. No cruzamento $\mathrm{MxS}$ e retrocruzamento $\mathrm{Mx}(\mathrm{SM})$, os ovos deformados produzidos, dos quais não foi verificada a eclosão de larvas, poderiam corresponder a fêmeas, o que corresponderia à inviabilidade dos ovos que se mantiveram diplóides, como resultado da combinação do genótipo de origem materna $(\mathrm{M})$ e paterna $(\mathrm{S})$. $\mathrm{O}$ fluxo gênico entre as populações $\mathrm{S}$ e $\mathrm{M}$ é entretanto possível indiretamente, através da população R. Isto se conclui tendo em vista que $\mathrm{M}$ é compatível com $\mathrm{R}$ e este último é pelo menos parcialmente compatível com $\mathrm{S}$. 
No retrocruzamento $\mathrm{Sx}(\mathrm{RS})$ era esperada uma progênie constituída somente de machos, semelhantemente ao resultado obtido no cruzamento SxR. Entretanto, por alguma razão, ambos os sexos foram produzidos.

A ocorrência de machos apresentando material genético materno dentro do processo de pseudo-arrenotoquia continua sendo pesquisada. No estudo de 2 populações de Typhodromus pyri Scheuten, Perrot-Minnot \& Navajas (1995), obtiveram evidências da contribuição genética paterna na produção de machos haplóides. Se considerarmos esta possibilidade, ou seja, que o macho haplóide também contenha material genético paterno, a ocorrência de algum fluxo gênico se verificaria mesmo nos casos daqueles cruzamentos em que tenha sido verificado apenas a presença de descendentes machos (SR, RP, SP, MP, VP, MS, SM e SV). Entretanto, não se tem conhecimento se esse material genético paternal é transmitido para as próximas gerações através dos descendentes machos da geração F1 (Perror-Minnot \& Navajas, 1995), além de que, são necessários estudos para a comprovação de que $T$. pyri se reproduza pelo processo de pseudo-arrenotoquia. Estudo recente conduzido por Perrot-Minnot et al. (2000) com Neoseiulus californicus (McGregor) sugere que o genoma paterno conservado no macho haplóide da geração F1 não é transmitido através do esperma para o descendente do retrocruzamento de fêmea parental e macho da geração F1.

Existe uma aparente incompatibilidade reprodutiva entre as fêmeas de Petrolina e os machos das demais populações estudadas, caracterizado como do tipo pósacasalamento, já que mesmo sem a produção de progênie ocorreu a transferência de espermas do macho para a fêmea. Esta hipótese também foi apresentada por Furtado (1997), ao considerar as populações de Petrolina e Jaguariúna. A incompatibilidade reprodutiva entre aquelas populações aparentemente ocorre entre a inseminação das fêmeas e a fase em que os ovos se tornam visíveis em seu interior. Já nos cruzamentos heterogâmicos envolvendo machos de Petrolina, a incompatibilidade não foi total, e aparentemente ocorreu após a fertilização dos óvulos, de vez que a oviposição foi verificada e que a fertilização é um pré-requisito para que a oviposição ocorra em espécies pseudo-arrenótocas. Entretanto, o número reduzido de ovos nestes casos indica que a incompatibilidade se deu entre as fases inseminação e oviposição. Nos 
cruzamentos e retrocruzamentos envolvendo fêmeas de Petrolina, é possível que tenha ocorrido a mortalidade gamética e/ou mortalidade do zigoto, já que algumas fêmeas, apesar de não ovipositarem, apresentavam endospermatóforos no interior das espermatecas.

Os resultados deste trabalho foram semelhantes aos de Furtado (1997) com relação aos cruzamentos heterogâmicos das populações de Jaguariúna e Petrolina, indicando um isolamento reprodutivo entre as populações. Congdon \& McMurtry (1986) demonstraram através de cruzamentos uma compatibilidade reprodutiva parcial entre Euseius quetzali McMurtry e Euseius hibisci (Chant) procedentes da Califórnia. O cruzamento de fêmeas de E. quetzali com machos de E. hibisci não produziu progênie, embora o cruzamento recíproco tenha produzido progênie constituída somente de machos. Estes, quando analisados através de caracteres morfológicos se apresentaram semelhantes aos machos de E. hibisci, sugerindo que esta espécie é pseudo-arrenótoca (parahaplóide) (Congdon \& McMurtry, 1988).

Tivesse sido Wolbachia a razão das incompatibilidades observadas nos cruzamentos PxR, PxS, PxM e PxV, os cruzamentos complementares (RxP, SxP, MxP e $\mathrm{VxP}$ ) deveriam apresentar compatibilidade normal, o que não ocorreu nestes casos, em que todos os descendentes eram machos. Dados obtidos anteriormente por Furtado (1997) indicaram que a incompatibilidade entre populações de Jaguariúna e Petrolina não se devia à presença de Wolbachia. Mesmo após tratamento daquelas populações com antibiótico (Tetraciclina $\left.{ }^{\circledR}\right)$, aquela autora continuou obtendo oviposição somente quando as fêmeas eram de Jaguariúna, resultando na produção de machos. Do mesmo modo que no capítulo 4, três análises ao nível molecular foram realizadas na Universidade de Amsterdam para a detecção de Wolbachia nas populações de $E$. concordis, sem resultados conclusivos.

Nos cruzamentos heterogâmicos envolvendo fêmeas de Petrolina, é possível a presença de alguma substância química na espermateca poderia estar impedindo a ação dos espermatozóides. Outra hipótese seria que alguma substância presente no processo de formação do endospermatóforo poderia levar à incompatibilidade em alguns casos, impedindo a ação dos espermatozóides, supondo-se neste caso, o endospermatóforo 
formado com material proveniente do esperma juntamente com o material existente na espermateca. Hoy \& Cave (1988) verificaram isolamento pós-cópula em colônias de Galendromus occidentalis (Nesbitt). A incompatibilidade resultou na redução do número de ovos, ovos deformados dos quais as larvas não eclodiram, redução do número absoluto de fêmeas da progênie e consequente aumento da razão sexual em favor de machos. As fêmeas aparentemente tinham espermatóforos depositados em suas espermatecas. Os autores citaram que a incompatibilidade poderia ser devido à falta de penetração do esperma nos óvulos, falta de singamia, incompatibilidade do esperma e citoplasma do óvulo ou incompatibilidade dos genomas. Schulten (1985) citou que após a inseminação da fêmea o endospermatóforo pode permanecer presente por um período prolongado na espermateca, ou desaparecer gradualmente 1 a 2 dias após a inseminação, não estando claro o que ocorre com os espermatozóides. Amano \& Chant (1978) sugeriram que o endospermatóforo (que contém o esperma no interior da espermateca) é injetado como um líquido ou é o resultado de uma reação química entre o conteúdo da espermateca e o material transferido pelo macho. Furtado (1997) observou maior número de endospermatóforos nos cruzamentos e retrocruzamentos heterogâmicos, sugerindo que nestes cruzamentos e retrocruzamentos, devido a alguma incompatibilidade reprodutiva, os endospermatóforos permanecem distintos na espermateca por um período prolongado.

Ao contrário do que foi observado para outras populações, a inexistência de endospermatóforos nas fêmeas de Petrolina mantidas juntas com machos de Viçosa durante 48 horas sugere alguma dificuldade na tentativa da cópula. Há que se considerar entretanto, que a presença de endospermatóforos nas fêmeas da população de Viçosa foi observada após um período mais prolongado de observação. A inseminação daquelas fêmeas eventualmente ocorreu após um longo período.

Pelos resultado obtidos, não foi possível comprovar que a população de Petrolina pertence à mesma espécie das demais populações testadas, apesar da caracterização morfológica realizada no capítulo 3 não ter permitido com segurança uma diferenciação morfológica entre todas as populações. Um estudo das populações de $E$. 
concordis ao nível molecular pode fornecer informações que auxiliem no entendimento dessas incompatibilidades.

\subsection{Conclusões}

- As populações identificadas como E. concordis de Arroio do Meio-RS, JaguariúnaSP, Pontes e Lacerda-MT e Viçosa-MG pertencem a uma mesma espécie.

- Existe fluxo gênico direto entre a população procedente de Arroio do Meio e as populações de Jaguariúna e Pontes e Lacerda, quando estas são colocadas em contato.

- Existe uma aparente incompatibilidade parcial entre as populações de Jaguariúna e Viçosa, e Jaguariúna e Pontes e Lacerda.

- A incompatibilidade reprodutiva entre a população de Petrolina-PE e as demais populações estudadas é caracterizada como do tipo pós-acasalamento, e provavelmente não se deve à ação da bactéria simbionte Wolbachia. 


\section{CARACTERIZAÇÃO MOLECULAR DE POPULAÇÕES IDENTIFICADAS COMO Euseius citrifolius E Euseius concordis (ACARI, PHYTOSEIIDAE)}

\section{RESUMO}

A identificação precisa é o passo inicial na seleção de inimigos naturais usados em um projeto de controle biológico. A identificação dos ácaros geralmente é feita com base nas características morfológicas. Entretanto, as evidências morfológicas nem sempre são suficientes para a distinção de espécies muito próximas, levando o taxonomista a considerar aspectos ecológicos, biológicos e, mais recentemente, as características moleculares A caracterização molecular de populações de Euseius citrifolius Denmark \& Muma e Euseius concordis (Chant) foi realizada neste trabalho através do seqüenciamento da região dos espaçadores internos transcritos (ITS1 e ITS2) do DNA ribossomal. Os ácaros foram obtidos de colônias estabelecidas cerca de 60 dias antes, com espécimes coletados em campo nos seguintes substratos e locais de coleta: $E$. citrifolius: Bauhinia sp. em Arroio do Meio-RS, Coffea arabica L. em Campinas-SP e Terminalia catappa L. em Petrolina-PE; E. concordis: Passiflora edulis Sims. f. flavicarpa Deg. em Arroio do Meio, Manihot esculenta (Crantz) em Jaguariúna-SP, Hevea brasiliensis Muell. Arg. em Pontes e Lacerda-MT, T. catappa em Petrolina e $C$. arabica em Viçosa-MG. Maior variação entre as populações foi observada no espaçador ITS1 que no espaçador ITS2. O seqüenciamento dos ITS 1 e 2 permitiu discriminar os grupos de populações identificadas como E. citrifolius daquelas identificadas como $E$. 
concordis. O seqüenciamento dos espaçadores ITSs pode ser aplicado como uma ferramenta complementar na identificação de espécies de fitoseídeos.

\section{MOLECULAR CHARACTERIZATION OF POPULATIONS IDENTIFIED AS Euseius citrifolius AND Euseius concordis (ACARI, PHYTOSEIIDAE)}

\section{SUMMARY}

The precise species identification is the initial step in the selection of natural enemies to be used in a biological control project. Mites have usually been identified by their morphological characteristics. However, morphological evidences are not always sufficient to allow the distinction between closely related species, leading taxonomists to consider additional ecological, biological and, more recently, molecular characteristics in this process. The molecular characterization of populations of Euseius citrifolius Denmark \& Muma and Euseius concordis (Chant) was done in this work by sequencing the internal transcribed spacers of the ribosomal DNA (ITS1 and ITS2). Mites used were obtained from colonies established with specimens collected in the field ca. 60 days before the work was initiated, on the following plants and sites: $E$. citrifolius: Bauhinia sp. in Arroio do Meio-RS, Coffea arabica L. in Campinas-SP and Terminalia catappa L. in Petrolina-PE; E. concordis: Passiflora edulis Sims. f. flavicarpa Deg. in Arroio do Meio, Manihot esculenta (Crantz) in Jaguariúna-SP, Hevea brasiliensis Muell. Arg. in Pontes e Lacerda-MT, T. catappa in Petrolina and C. arabica in Viçosa-MG. Most of the variation between populations was observed in ITS1 than in ITS2. The sequencing of ITS1 and ITS2 allowed the discrimination between the group of populations identified as E. citrifolius from that identified as E. concordis. With the 
information presently available, sequencing of ITSs can be applied as a complementary tool in the identification of phytoseiid species.

\subsection{Introdução}

Ácaros da família Phytoseiidae são eficientes inimigos naturais de ácaros fitófagos e vêm sendo utilizados em condições de campo e de casa-de-vegetação no controle de ácaros pragas Bellotti et al., 1999; McMurtry, 1992; Rasmy \& Ellaithy, 1988). Moraes (1987) citou que a taxonomia é o ponto de partida para a introdução, conservação e incremento de agentes de controle biológico. A identificação de fitoseídeos é usualmente feita com base em características morfológicas, sendo que muitas vezes somente essas evidências não são suficientes para a distinção segura entre espécies muito parecidas.

Para o esclarecimento de possíveis dúvidas, aspectos ecológicos, biológicos e, mais recentemente, a caracterização molecular vêm sendo usadas em complemento aos aspectos morfológicos para diferentes grupos de organismos. Alguns trabalhos na área da caracterização molecular vêm sendo realizados com ácaros (Navajas et al., 1992, 1994 e 1997).

Um trabalho preliminar com fitoseídeos foi realizado por Navajas et al. (1999), para verificar o nível de variação nas seqüências da região dos espaçadores internos transcritos - ITS 1 e 2 (do inglês, "Internal Transcribed Spacer"), do DNA ribossomal. As espécies estudadas foram Neoseiulus californicus (McGregor), Neoseiulus fallacis (Garman), Euseius concordis (Chant), Galendromus occidentalis (Nesbitt), Typhlodromus pyri Scheuten e Phytoseiulus persimilis Athias-Henriot. Os autores verificaram que a região do espaçador ITS1 apresentou maior comprimento, ou seja, maior número de pares de bases, e maior variação na seqüência de nucleotídeos que o espaçador ITS2. Conseqüentemente, sugeriram que as regiões dos ITSs possam ser usadas para a separação de espécies de fitoseídeos. Regiões espaçadoras evoluem 
rapidamente e de forma diferenciada entre populações, e podem ser usadas para diferenciar espécies ou populações de uma mesma espécie. Essas regiões vêm sendo seqüenciadas em diversos organismos como o homem, o rato, o camundongo, espécies de vegetais, fungos, insetos e ácaros (Ciociola Junior, 2000; Hoy, 1994; Navajas et al., 1992, 1994 e 1997; Torres et al., 1990).

Furtado (1997) verificou pequenas diferenças morfológicas entre populações de Euseius concordis (Chant) de Jaguariúna-SP e Petrolina-PE, sugerindo estudos adicionais para uma conclusão definitiva sobre a existência de duas espécies distintas.

Apesar das variações nas medições apresentadas no capítulo 3 desta tese, não foi possível estabelecer uma diferenciação morfológica segura entre as populações das 2 espécies estudadas. Entretanto, permitiu a diferenciação da população de Euseius citrifolius Denmark \& Muma de Petrolina e de E. concordis de Jaguariúna das demais populações estudadas correspondentes. Os resultados de testes de cruzamentos constantes nos capítulos 4 e 5 mostraram um certo grau de incompatibilidade reprodutiva entre populações de E. citrifolius, e a ocorrência de incompatibilidade reprodutiva parcial ou total entre certas populações de E. concordis. Para uma conclusão neste aspecto, um estudo em nível molecular pode fornecer importantes subsídios para o conhecimento das variações moleculares nestas populações e a complementação dos resultados dos capítulos anteriores.

O objetivo deste trabalho foi verificar a viabilidade do uso da caracterização molecular como uma ferramenta adicional na identificação de espécies de fitoseídeos, com um estudo de caso. Este estudo envolveu a amplificação e o seqüenciamento dos espaçadores internos transcritos (ITS1 e ITS2) do DNA ribossomal de populações identificadas como E. citrifolius e E. concordis, complementando as avaliações morfológicas e biológicas previamente realizadas. 


\subsection{Material e Métodos}

Foram estudadas duas espécies de fitoseídeos identificadas através de caracteres morfológicos como E. citrifolius e E. concordis. Colônias das 2 espécies foram estabelecidas em laboratório a partir de espécimes procedentes das seguintes populações: E. citrifolius coletados de Bauhinia sp. em Arroio do Meio-RS, Coffea arabica L. em Campinas-SP e Terminalia catappa L. em Petrolina-PE; E. concordis coletados de Passiflora edulis Sims. f. flavicarpa Deg. em Arroio do Meio, Manihot esculenta (Crantz) em Jaguariúna-SP, Hevea brasiliensis Muell. Arg. em Pontes e Lacerda-MT, T. catappa em Petrolina e C. arabica em Viçosa-MG. A localização dos pontos de coleta, assim como o número de indivíduos para o início das colônias foram apresentados no capítulo 3.

Amostras de 20 fêmeas da população correspondente a cada colônia foram coletadas até 60 dias após o estabelecimento. Cada fêmea foi individualizada em tubos “eppendorf” de $0,5 \mathrm{~mL}$ e conservadas a $-80{ }^{\circ} \mathrm{C}$ até o momento da extração de DNA.

As atividades de caracterização molecular foram realizadas no Laboratório de Biotecnologia Animal do Departamento de Produção Animal da ESALQ/USP.

Otimização das condições para a caracterização molecular: Testes preliminares foram realizados para adaptação do protocolo descrito por Navajas et al. (1999), às condições deste estudo. Os testes foram conduzidos com amostras de fitoseídeos provenientes das mesmas colônias de onde as amostras para a caracterização molecular definitiva haviam sido retiradas. A otimização da etapa de extração de DNA foi iniciada com 20 ácaros. Testou-se primeiramente a melhor maneira para a maceração dos ácaros. $\mathrm{Na}$ etapa da reação em cadeia da polimerase (PCR), foram feitos testes para verificar a melhor concentração de $\mathrm{MgCh}$, o número mais adequado de ácaros para a extração de DNA (1, 3 ou 5) e a quantidade do produto de amplificação (2 ou $5 \mu \mathrm{L})$ para a corrida no gel de agarose. Para a purificação do produto de PCR, as amostras foram testadas com e sem a utilização de vacuômetro. Além disso, foram feitos testes com a eluição do fragmento de DNA em 20, 30 e $50 \mu \mathrm{L}$ de água Milli Q. 
Extração de DNA: A extração de DNA foi realizada seguindo o protocolo descrito por Navajas et al. (1999), com pequenas modificações. Fêmeas individualizadas no interior de tubos "eppendorf" de 1,5 mL foram maceradas a seco e sob estereomicroscópio com uma pipeta de Pasteur que teve a extremidade flambada para a formação de uma pequena esfera. Em seguida, cada tubo recebeu $200 \mu \mathrm{L}$ do tampão de extração (2\% CTAB, 1,4 M NaCl, 0,2\% 2- $\beta$ mercaptoetanol, 20 mM EDTA, $100 \mathrm{mM}$ Tris- $\mathrm{HCl} \mathrm{pH} \mathrm{8,0)} \mathrm{e} \mathrm{foi} \mathrm{mantido} \mathrm{em} \mathrm{banho-maria} \mathrm{a} 60{ }^{\circ} \mathrm{C}$ por 20 minutos. Em cada amostra, foram então adicionados $200 \mu \mathrm{L}$ de uma mistura de clorofórmio e álcool isoamílico (24:1), sendo o material homogeneizado e centrifugado por 15 minutos a $11.000 \mathrm{xg}$ à temperatura ambiente. O sobrenadante foi retirado e transferido para novo tubo de mesmo volume, sendo o DNA então precipitado pela adição de igual volume de isopropanol gelado e incubação a $-20{ }^{\circ} \mathrm{C}$ por 1 hora. Em seguida, o material foi centrifugado por 10 minutos a $11.000 \mathrm{xg}$, sendo o sobrenadante descartado. $\mathrm{O}$ precipitado foi lavado com $500 \mu \mathrm{L}$ de etanol $75 \%$ e centrifugado por 15 minutos a $11.000 \mathrm{xg}$. O precipitado foi secado em temperatura ambiente e ressuspendido em $20 \mu \mathrm{L}$ de água Milli Q, sendo armazenado a $-20^{\circ} \mathrm{C}$ até o momento da amplificação.

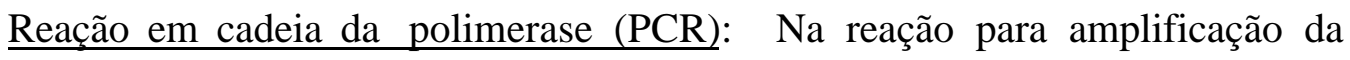
região do espaço interno transcrito - ITS (espaçadores ITS1 e ITS2) foram usados os "primers" citados por Navajas et al. (1999), aqui denominados de P1 (5'AGAGGAAGTAAAAGTCGTAACAAG-3)', idênticos aos nucleotídeos localizados no na região 18S do DNAr e P2 (5'-ATATGCTTAAATTCAGGGGG-3'), idênticos aos nucleotídeos localizados na região 28S do DNAr conforme representação na Figura 2. 


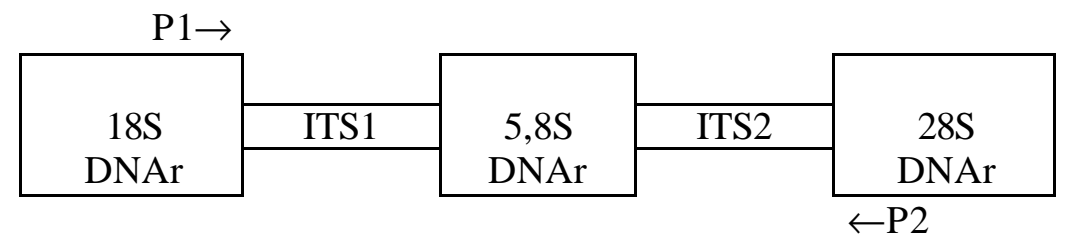

Figura 2- Região do DNA ribossomal amplificada por PCR (Espaçador ITS1, gene 5,8S e espaçador ITS2). As setas indicam a posição dos primers P1 (na região $18 \mathrm{~S}$ ) e P2 (na região $28 \mathrm{~S}$ ).

Cada reação foi feita num volume total de $50 \mu \mathrm{L}$, com $5 \mu \mathrm{L}$ de amostra de DNA e $45 \mu \mathrm{L}$ da mistura [5 $\mu \mathrm{L}$ do tampão de PCR 10X, $1 \mu \mathrm{L}$ de dNTP (10 mM), $5 \mu \mathrm{L}$ de cada primer $(5 \mu \mathrm{M}), 5 \mu \mathrm{L}$ de $\mathrm{MgCh}_{2}(2,5 \mathrm{mM}), 0,5 \mu \mathrm{L}$ de TAQ polimerase $(5 \mathrm{U} / \mu \mathrm{L}) \mathrm{e}$ 23,5 $\mu \mathrm{L}$ de água Milli $\mathrm{Q}$ autoclavada]. As amplificações foram realizadas em termociclador PCT-100 M. J. Research, utilizando um programa de amplificação consistindo de um ciclo inicial de 1 minuto a $94{ }^{\circ} \mathrm{C}$, seguido de 30 ciclos para uma sequiência específica ( 1 minuto a $93{ }^{\circ} \mathrm{C}, 1$ minuto a $50{ }^{\circ} \mathrm{C}$ e 1 minuto de $72{ }^{\circ} \mathrm{C}$ ), e um ciclo final de 5 minutos a $72{ }^{\circ} \mathrm{C}$. Foram realizadas 4 reações de amplificação para cada amostra de DNA constituída de $20 \mu \mathrm{L}$.

O produto de cada reação de PCR foi analisado por eletroforese em gel de agarose a $1 \%$ corado com brometo de etídeo $(10 \mathrm{mg} / \mathrm{mL})$, para a confirmação do sucesso da amplificação. As amostras foram preparadas utilizando-se $2 \mu \mathrm{L}$ de produto de PCR, 2 $\mu \mathrm{L}$ de solução de azul de bromofenol e $1 \mu \mathrm{L}$ de água Milli Q. Como marcador de peso molecular utilizou-se $\phi X 174$ RF digerido com Hae III. Os géis foram visualizados em transluminador de ultravioleta e fotografados com câmera digital acoplada a um computador com o programa "Kodak Digital Science TM".

Sequenciamento: Os produtos de PCR foram purificados utilizando o "Wizard ${ }^{\circ}$ PCR Preps DNA Purification System" antes de serem submetidos ao sequienciamento, seguindo-se as especificações de uso do fabricante. No preparo das amostras para a purificação, foram usados cerca de $190 \mu \mathrm{L}$ do produto de PCR de cada 
amostra de DNA, correspondentes às 4 reações de amplificação, permitindo a obtenção de maior quantidade de DNA. A purificação foi realizada sem utilização de vacuômetro por ser mais prático. O fragmento de DNA foi eluído em $20 \mu \mathrm{L}$ de água Milli $\mathrm{Q}$ autoclavada.

Os produtos de PCR purificados foram seqüenciados com o "DYEnamic ${ }^{\mathrm{TM}} \mathrm{ET}$ Terminator Cycle Sequencing Kit" usando os mesmos "primers" utilizados nas reações de amplificação. Foram seqüenciadas 3 amostras de cada população para cada "primer". Cada reação de seqüenciamento foi feita num volume total de $10 \mu \mathrm{L}$, correspondente a $4 \mu \mathrm{L}$ do produto de PCR purificado (400 ng de DNA), $2 \mu \mathrm{L}$ da mistura de reagentes constantes do kit, 1,0 $\mu \mathrm{L}$ do "primer" e $3 \mu \mathrm{L}$ de água Milli Q autoclavada. A reação foi conduzida em termociclador PCT-100 M. J. Research, com a programação consistindo de 30 ciclos de uma seqüência específica $\left(20\right.$ segundos a $95{ }^{\circ} \mathrm{C}, 15$ segundos a $50{ }^{\circ} \mathrm{C}$ e 1 minuto a $60{ }^{\circ} \mathrm{C}$ ) e um ciclo final de 5 minutos a $4{ }^{\circ} \mathrm{C}$.

Após a reação, o DNA foi precipitado pela adição ao produto da reação de seqüenciamento de $1 \mu \mathrm{L}$ do tampão acetato de sódio/EDTA (Acetato de sódio 1,5M, pH $>8,250 \mathrm{mM}$ EDTA) e $40 \mu \mathrm{L}$ de etanol 95\%. O material foi homogeneizado, mantido em temperatura ambiente por 15 minutos e posteriormente centrifugado a $12.000 \mathrm{xg}$ por 15 minutos. Após a retirada do álcool, com auxílio de uma pipeta, foram adicionados $250 \mu \mathrm{L}$ de etanol $70 \%$, centrifugando-se a amostra a 12.000 xg por 5 minutos e retirando-se posteriormente o álcool. $\mathrm{O}$ precipitado foi ressuspenso em $4 \mu \mathrm{L}$ de tampão de formamida, seguindo as instruções do kit de seqüenciamento.

As amostras foram submetidas à eletroforese em gel de acrilamida 5\% por 10 horas no seqüenciador automático de DNA ABI 377, da Applied Biosystems.

No alinhamento de todas as seqüências obtidas para cada "primer", foram utilizados os programas Phred/Phrap/Consed (University of Washington). As sequiências obtidas para cada população foram comparadas com seqüências disponíveis no banco de dados americano do 'National Center for Biotechnology Information NCBI" (GenBank) (www.ncbi.nlm.nih.gov) através do programa BLAST (Basic Local Alignment Search Tool). 


\subsection{Resultados}

O protocolo utilizado neste estudo envolvendo a extração de DNA de um ácaro, a reação de amplificação e a purificação do produto amplificado permitiu a obtenção de DNA suficiente para o seqüenciamento dos ITS 1 e 2, desde que pelo menos 4 reações de amplificação fossem realizadas para cada amostra de DNA. Para cada reação de seqüenciamento, foram necessários cerca de $400 \mathrm{ng}$ de DNA, equivalentes a 4-5 $\mu \mathrm{L}$ do produto de amplificação purificado, o que somente pode ser obtido com a junção do produto das 4 reações de amplificação.

Após alinhamento das seqüências obtidas para cada reação de seqüenciamento, verificou-se a formação de 2 conjuntos de alinhamentos distintos, um conjunto formado pelas seqüências dos indivíduos das populações identificadas como E. citrifolius e outro formado pelas populações identificadas como E. concordis. A similaridade entre as seqüências das 2 espécies foi superior a 94\%. As diferenças mais marcantes entre estas seqüências foram encontradas no espaçador ITS1, com similaridade superior a $94 \%$ (Figura 3). Comparando-se as seqüências do ITS1 das populações de E. citrifolius de Arroio do Meio e Campinas e de E. concordis de Arroio do Meio, Jaguariúna, Pontes e Lacerda e Viçosa, foram encontrados 11 polimorfismos. As seqüiências do ITS1 de $E$. citrifolius e E. concordis de Petrolina apresentaram 10 polimorfismos e um espaço (gap) para compensar uma deleção de nucleotídeo na última população ou uma inserção de nucleotídeo na população de E.citrifolius. Maior variação no ITS1 foi verificada comparando-se as seqüências de E. citrifolius de Arroio do Meio e Campinas e a seqüência da população de E. concordis de Petrolina , com 14 polimorfismos.

Como esperado, as seqüências do gene 5,8S apresentaram $100 \%$ de similaridade entre todas as populações das 2 espécies.

Poucas variações foram encontradas nas seqüências do espaçador ITS2 entre todas as populações das 2 espécies apresentando similaridade superior a $96 \%$. Comparando-se as sequiências do ITS2 das populações de E. citrifolius de Arroio do Meio e Campinas e de E. concordis de Arroio do Meio, Pontes e Lacerda e Viçosa foi verificado 1 polimorfismo (Figura 3). As sequiências do ITS2 das populações de 
Petrolina das 2 espécies não apresentaram variações. Um espaço e um polimorfismo foram verificados no alinhamento das seqüências de E. citrifolius de Arroio do Meio e Campinas e a seqüência de E. concordis de Jaguariúna.

A perda ou ganho de nucleotídeo é indicada por um traço na figura, já que é impossível distinguir uma inserção de uma deleção, não sendo visualizada diretamente nos dados tendo sua ocorrência inferida (Amorim, 1997). Os polimorfismos foram detectados em seqüências apresentando bases de alta qualidade, observadas através dos programas Phred/Phrap/Consed, indicando que essas variações são decorrentes de mutações e não de erros no seqüenciamento.

Comparando-se as seqüências das populações de E. citrifolius, verifica-se que a população de Petrolina apresenta 4 variações no espaçador ITS1 e 1 variação no espaçador ITS2 em relação às demais populações (Figura 4). Estas variações são denominadas de mutações de ponto, substituições ou polimorfismos simples de nucleotídeos (SNPs - do inglês, "Single Nucleotide Polymorphism"). As sequiências das populações de $E$. citrifolius se apresentaram muito similares às seqüências de $E$. finlandicus (população de Jokioinen-Finlândia) e de E. concordis (população de Petrolina-Brasil), previamente depositadas no GenBank com números de acesso AF202993 e Y18270, respectivamente.

Comparando-se as sequiências das populações de E. concordis, verifica-se que a região espaçadora ITS apresenta baixo nível de polimorfismo (Figura 5). Foram encontradas 3 variações na população de Petrolina em relação às outras populações, 2 constituídas por substituições de nucleotídeos localizadas na região do espaçador ITS1 e uma pela introdução também nessa região de um espaço. Encontrou-se uma variação na região do espaçador ITS2 da população de Jaguariúna em relação às demais populações, correspondente à introdução de um espaço na sequiência daquela população.

Estas constatações concordam com os resultados do capítulo 3, que mostram uma distinção das populações de Petrolina e, especialmente de Jaguariúna em relação às outras populações quando apenas as médias das medições de diferentes estruturas são consideradas. Estas constatações são também compatíveis com os resultados do capítulo 


\section{ITS1}

ACCTGCGGAA

.........

90
TTAGACTCCT

$\ldots \ldots \ldots$

$\begin{array}{r}170 \\ \hline \text { r }\end{array}$

........

250

ATCCCGACAA

.......

330

CACTTAGTCC

........

330

CACTTAGTCC

........

410

TTTGAATGAA

........

490

ACCTTTGCTG

........

570

TTATGACGTG
20
GgATCATTAC

A. .......

100
GCAGACCGGC

........

180
TTGCGCTGTG

.... T...

260

TACCTTTACT

C........

340

TTAAATCGAT

.......

340

TTAAATCGAT

.......

420

AATTTCAGCA

ITS2

500

CAGCCCTTGT 28S

$\Downarrow \quad 580$

TATCTGAAA
30
TGATTGAAAA

........

110
GAATCGCTGG

........

190

GCACGCTGCT

270

TCGTTACGAA

.... . .

350

GAAAAACATA

.......

350
GAAAAACATA

.......

$$
430
$$

CGGACACTTC

........

510

CGGCACGCTA

.......

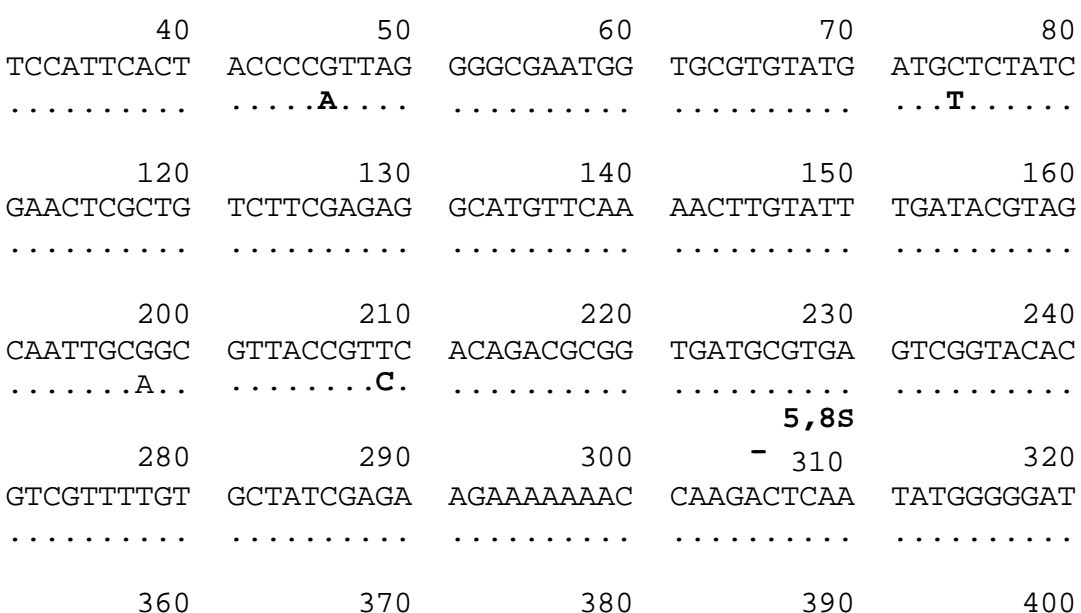

GtAAtTtgtg GAAAtgAtg tgagttgtgA AAtTttgtga GCAttgtgtT

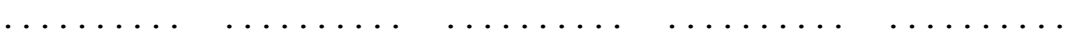

$\begin{array}{llll}360 & 370 & 380 & 390\end{array}$

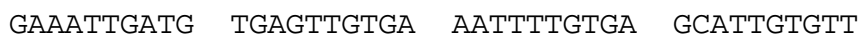

$\begin{array}{rrrr}\ldots \ldots \ldots & \ldots \ldots \ldots & \ldots \ldots \ldots \ldots & \ldots \ldots \ldots\end{array}$

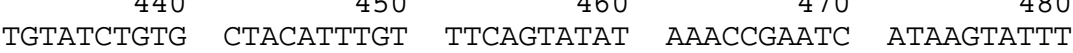

$\ldots \ldots \ldots \ldots \ldots \ldots \ldots \ldots \ldots \ldots \ldots \ldots \ldots \ldots \ldots$

$$
520 \quad 530 \quad 540 \quad 550 \quad 560
$$

TgCAAtggtA TAAAtTCtCA TTGgtCACGA GAgtgAtACC AACCCAACCA

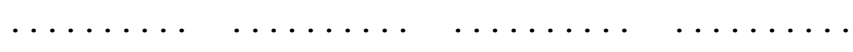

Figura 3 - Alinhamento das seqüências dos espaçadores ITS1 e IT2, e do gene 5,8S do DNA ribossomal de populações identificadas como Euseius citrifolius (Eci) (Arroio do Meio-RS e Campinas-SP), e E. concordis (Eco) (Arroio do Meio, Pontes e Lacerda-MT e Viçosa-MG). ( . ) caracteres idênticos com a segunda sequiência ( - ) inserção/deleção. 
ITS1

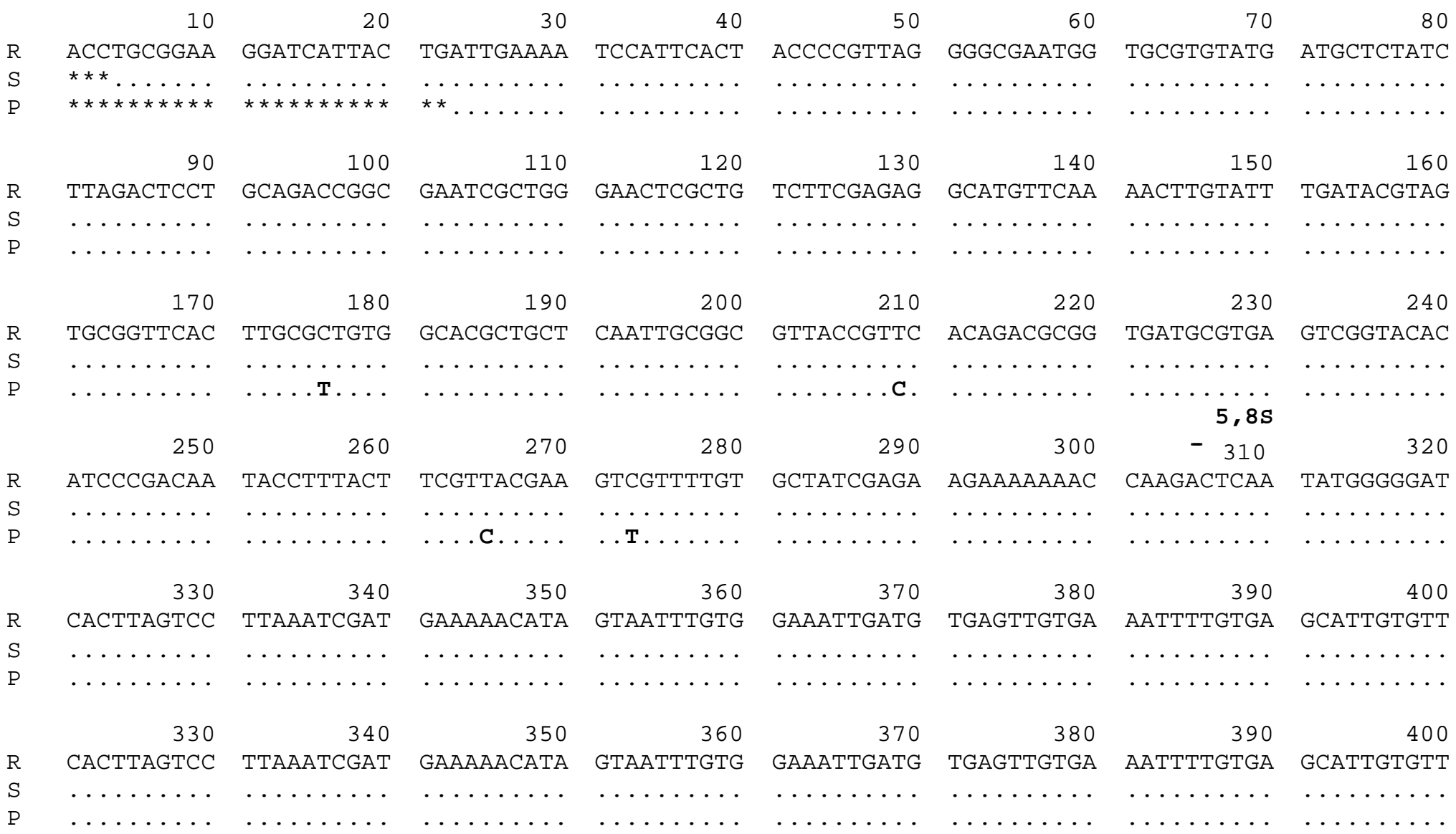

Figura 4 - Alinhamento das seqüências dos espaçadores ITS1 e IT2, e do gene 5,8S do DNA ribossomal de populações identificadas como Euseius citrifolius procedentes de Arroio do Meio-RS (R), Campinas-SP (S) e Petrolina-PE (P)

(*) trecho não seqüenciado ( . ) caracteres idênticos com a primeira seqüência. 


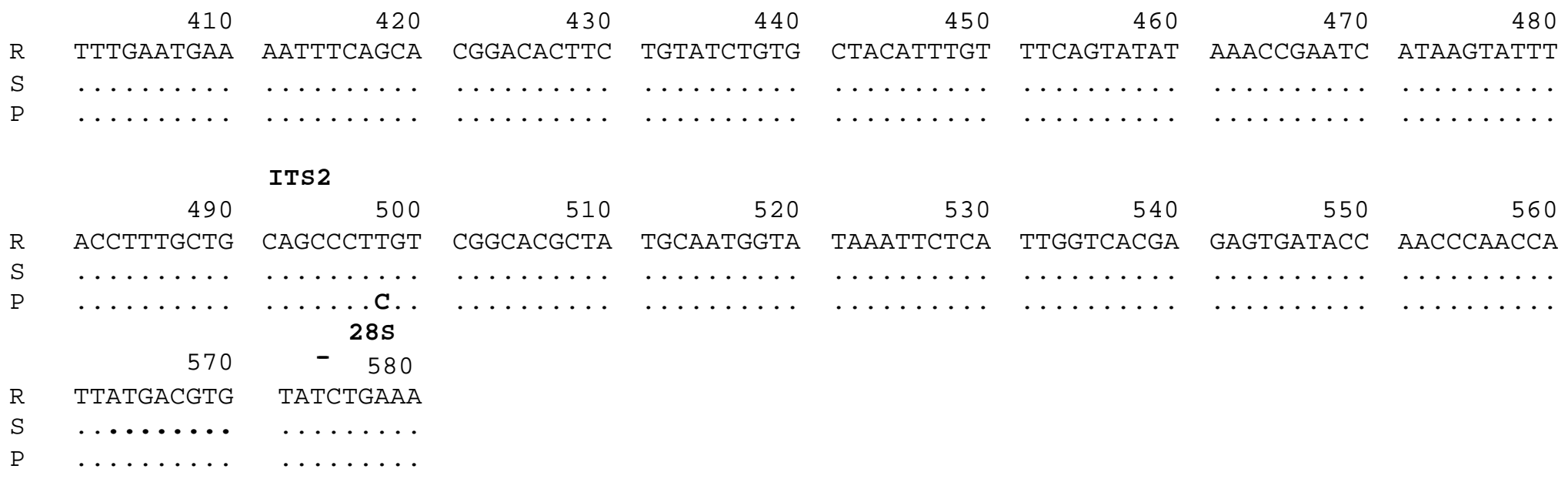

Figura 4 - Alinhamento das seqüências dos espaçadores ITS1 e IT2, e do gene 5,8S do DNA ribossomal de populações identificadas como Euseius citrifolius procedentes de Arroio do Meio-RS (R), Campinas-SP (S) e Petrolina-PE (P)

(*) trecho não seqüenciado ( . ) caracteres idênticos com a primeira seqüência. 


\begin{tabular}{|c|c|c|c|c|c|c|c|c|}
\hline & ITS1 & & & & & & & \\
\hline & 10 & 20 & 30 & 40 & 50 & 60 & 70 & 80 \\
\hline 8270 & ACCTGCGGAA & A---TTTTAC & TGAT TAAAAA & TCCATTCACT & ACCCCATTAG & GG-CGAATGG & TGCGTGTATG & ATGCTCTATC \\
\hline $\mathrm{R}$ & ACCTGCGGAA & AGATCATTAC & TGATTAAAAA & TCCATTCACT & ACCCCATTAG & GGGCGAATGG & TGCGTGTATG & ATGTTCTATC \\
\hline $\mathrm{S}$ & …...... & $\cdots \cdots \cdots \cdots$ & $\ldots \ldots \ldots$ & $\ldots \ldots \ldots$ & $\ldots$ & $\cdots$ & $\cdots \cdots$ & $\cdots$ \\
\hline M & $\cdots$ & $\ldots \ldots$ & $\ldots \ldots \ldots$ & $\ldots \ldots \ldots$ & $\ldots \ldots$ & $\ldots \ldots$ & $\ldots \ldots \ldots$ & $\cdots$ \\
\hline P & $\ldots \ldots$ & $\ldots \ldots \ldots$ & $\ldots \ldots \ldots$ & $\ldots \ldots \ldots$ & $\cdots$ & $\ldots$ & $\ldots$ & $\cdots$ \\
\hline $\mathrm{V}$ & $\ldots \ldots$ & $\ldots \ldots \ldots$ & $\ldots \ldots \ldots$ & $\ldots \ldots \ldots$ & $\ldots \ldots \ldots$ & $\ldots \ldots \ldots$ & $\ldots$ & \\
\hline & 90 & 100 & 110 & 120 & 130 & 140 & 150 & 160 \\
\hline 18270 & TTAGACTCCT & GCAGACCGGC & GAATCGCTGG & GAACTCGCTG & TCTTCGAGAG & GCATGTTCAA & A-CTTGTATT & TGATACGTAG \\
\hline $\mathrm{R}$ & TTAGACTCCT & GCAGACCGGC & GAATCGCTGG & GAACTCGCTG & TCTTCGAGAG & GCATGTTCAA & AACTTGTATT & TGATACGTAG \\
\hline S & $\ldots \ldots \ldots$ & $\ldots \ldots \ldots$ & $\ldots \ldots \ldots$ & $\ldots \ldots \ldots$ & $\ldots \ldots \ldots$ & $\ldots \ldots \ldots$ & $\ldots \ldots \ldots$ & $\cdots$ \\
\hline M & $\ldots \ldots \ldots$ & $\ldots \ldots \ldots$ & $\ldots \ldots \ldots$ & $\ldots \ldots \ldots$ & $\ldots \ldots \ldots$ & $\ldots \ldots \ldots$ & $\ldots$ & $\ldots \ldots$ \\
\hline $\mathrm{P}$ & $\ldots \ldots \ldots$ & $\ldots \ldots \ldots$ & $\ldots \ldots \ldots$ & $\ldots \ldots \ldots$ & $\ldots \ldots \ldots$ & $\ldots \ldots$ &.- & \\
\hline $\mathrm{V}$ & $\ldots \ldots \ldots$ & $\ldots \ldots \ldots$ & $\ldots \ldots \ldots$ & $\ldots \ldots \ldots$ & $\ldots \ldots \ldots$ & $\ldots \ldots \ldots$ & $\ldots \ldots \ldots$ & \\
\hline & 170 & 180 & 190 & 200 & 210 & 220 & 230 & 24 \\
\hline Y18270 & TGCGGTTCAC & TTGCGTTGTG & GCACGCTGCT & TAATTGCAGC & -TTACCGTCC & ACAGACGCG- & TGATGC-TGA & GTCGGTACAC \\
\hline $\mathrm{R}$ & TGCGGTTCAC & TTGCGTTGTG & GCACGCTGCT & CAATTGCAGC & GTTACCGTCC & ACAGACGCGG & TGATGCGTGA & GTCGGTACAC \\
\hline S & $\cdots \cdots$ & $\cdots$ & $\cdots \cdots \cdots$ & $\cdots \cdots$ & $\cdots$ & $\ldots \ldots \ldots$ & $\cdots$ & \\
\hline M & $\cdots \cdots$ & $\cdots$ & $\ldots \ldots \ldots$ & $\ldots \ldots \ldots$ & $\cdots$ & $\cdots$ & $\cdots \cdots$ & $\cdots$ \\
\hline $\mathrm{P}$ & $\ldots \ldots \ldots$ & $\ldots \ldots \ldots$ & $\ldots \ldots \ldots$ & т...... & $\ldots \ldots \ldots$ & $\ldots \ldots \ldots$ & $\ldots \ldots \ldots$ & $\cdots \cdots$ \\
\hline V & $\cdots \cdots$ & $\cdots$ & …...... & …...... & $\cdots$ & $\cdots$ & $3,8 s$ & \\
\hline & 250 & 260 & 270 & 280 & 290 & 300 & $\Downarrow 310$ & 320 \\
\hline Y18270 & ATCC-GACAC & САTСTTTACT & TCGTCATGA- & GTCGTTT-GT & GCTATCGAGA & -GAAAAA--C & CAAGACTCAA & TATGGG--AT \\
\hline $\mathrm{R}$ & ATCCCGACAC & САССТTTACT & TCGTCATGAA & GTCGTTTTGT & GCTATCGAGA & AGAAAAAAAC & CAAGACTCAA & TATGGGGGAT \\
\hline$S$ & $\ldots \ldots \ldots$ & $\ldots \ldots \ldots$ & $\cdots \ldots \ldots$ & $\cdots \ldots \ldots$ & -......... & $\cdots \ldots \ldots$ & $\ldots \ldots \ldots$ & $\ldots \ldots \ldots$ \\
\hline$M$ & $\cdots$ & $\cdots$ & $\cdots \cdots$ & $\cdots \cdots \cdots \cdots$ & $\cdots$ & $\cdots$ & $\cdots$ & $\cdots$ \\
\hline $\mathrm{P}$ & & $\cdots \mathbf{T}$ & $\cdots$ & & & $\cdots$ & & \\
\hline$V$ & & & & & & & & \\
\hline
\end{tabular}

Figura 5 - Alinhamento das seqüências dos espaçadores ITS1 e ITS2, e do gene 5,8S do DNA ribossomal de populações identificadas como Euseius concordis procedentes de Arroio do Meio-RS (R), Jaguariúna-SP (S), Pontes e Lacerda-MT (M), Petrolina-PE (P) e Viçosa-MG (V). Y18270 - Acesso ao GenBank para seqüência de E. concordis de Petrolina-PE, depositada por Navajas et al. (1999). ( . ) caracteres idênticos com a segunda seqüência ( - ) inserção/deleção $\quad(*)$ trecho não seqüienciado. 


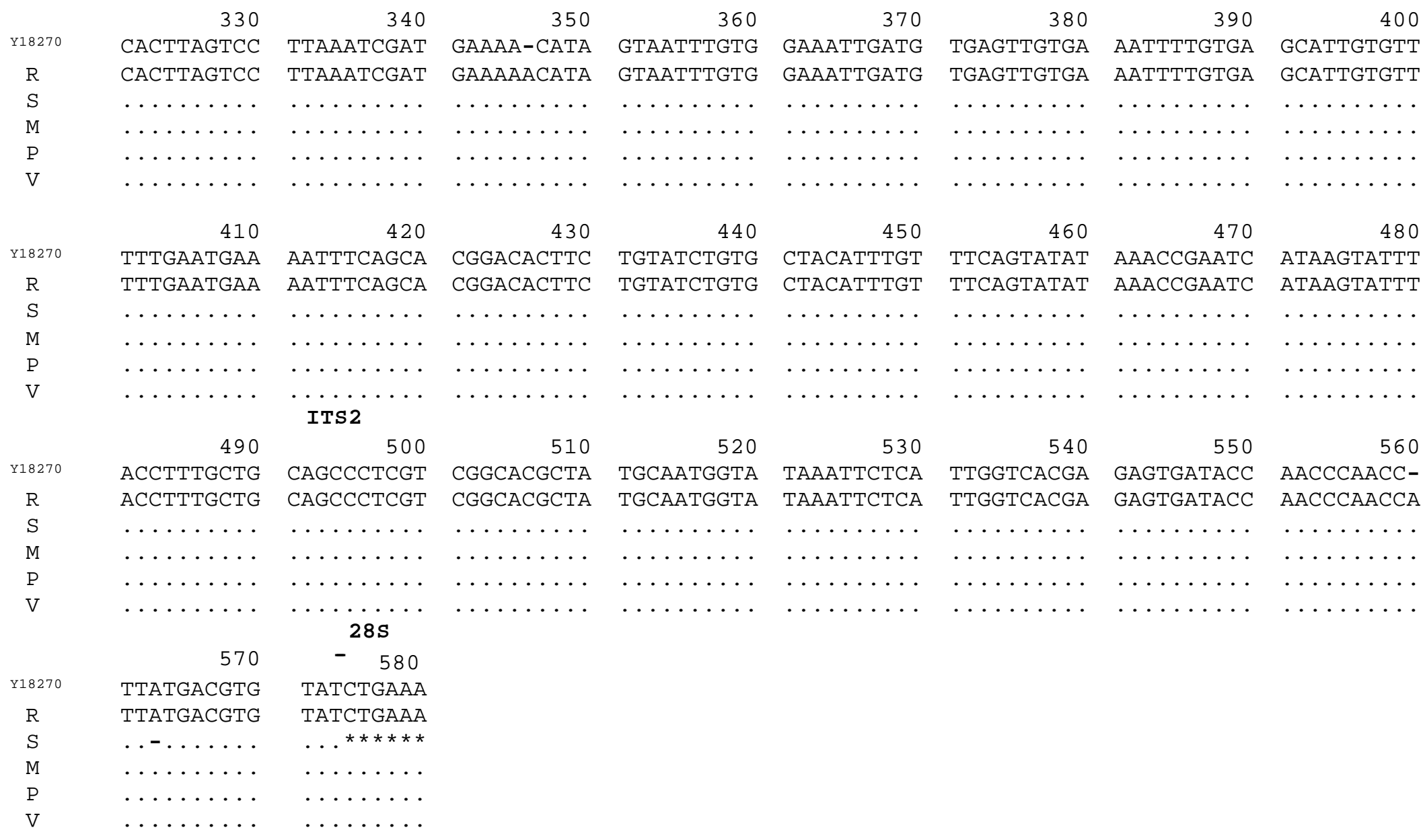

Figura 5 - Alinhamento das sequiências dos espaçadores ITS1 e ITS2, e do gene 5,8S do DNA ribossomal de populações identificadas como Euseius concordis procedentes de Arroio do Meio-RS (R), Jaguariúna-SP (S), Pontes e Lacerda-MT (M), Petrolina-PE (P) e Viçosa-MG (V). Y18270 - Acesso ao GenBank para sequiência de E. concordis de Petrolina-PE, depositada por Navajas et al. (1999).

( . ) caracteres idênticos com a segunda seqüência ( - ) inserção/deleção (*) trecho não seqüenciado. 
5 que mostram níveis maiores de incompatibilidade da população de Petrolina em relação a outras populações e de Jaguariúna, em relação a Pontes e Lacerda e Viçosa.

$\mathrm{O}$ alinhamento das sequiências de E. concordis obtidas neste trabalho com a seqüência para a mesma espécie, coletada em Petrolina e depositada por Navajas et al. (1999) no GenBank é apresentado na Figura 5. Os polimorfismos e espaço verificados na seqüência de bases dos espaçadores ITS1 e 2 da população de Petrolina estudada neste trabalho também são encontrados na seqüência depositada por Navajas et al. (1999) e a similaridade entre essas 2 seqüências foi de 97\%. A similaridade entre a seqüência depositada por Navajas et al. (1999) e as seqüências das populações de $E$. concordis relatadas neste trabalho foi superior a $95 \%$.

As seqüências do espaçador ITS1 obtidas neste trabalho apresentaram similaridade superior a $94 \%$ com a sequiência de E. concordis depositada por Navajas et al. (1999). Já o espaçador ITS2 apresentou similaridade superior a 96\% com aquela seqüência. As seqüências das populações obtidas neste trabalho se apresentaram muito mais similares às sequiências de E. concordis e E. finlandicus, que às seqüências das demais espécies de fitoseídeos depositadas no GenBank (N. fallacis, P. persimilis, $T$. pyri, N. californicus e G. occidentalis).

\subsection{Discussão}

A formação de 2 conjuntos de alinhamentos distintos separando E. citrifolius de E. concordis através das sequiências dos espaçadores ITS corroboram as sugestões de diferentes autores de que os dos espaçadores internos ITS1 e ITS2 são apropriadas para discriminar espécies relacionadas ou até mesmo variações dentro da mesma espécie (Fungaro et al., 2000; Gotoh et al., 1998; Navajas et al., 1999; Silva et al., 1999).

Obviamente, os resultados dos seqüenciamentos realizados neste estudo não permitem a identificação das espécies, considerando-se o reduzido número de seqüências disponíveis no GenBank para ácaros fitoseídeos. Adições de novas informações naquele banco poderão no futuro auxiliar esta atividade. Entretanto, este estudo forneceu informação para uma melhor interpretação dos resultados obtidos nos 
capítulos 4 e 5. As incompatibilidades e o isolamento reprodutivo verificados nos cruzamentos PxR, PxS (capítulo 4) e PxR, PxS, PxM, PxV (capítulo 5) são consistentes com as variações observadas neste estudo principalmente nas populações de Petrolina de E. citrifolius e E. concordis, e indicam que a incompatibilidade reprodutiva possa ser devida a fatores genéticos.

Os 5 polimorfismos encontrados na população de E. citrifolius de Petrolina podem ser um indicativo dessas diferenças, entretanto outros estudos devem ser conduzidos para o entendimento dessas variações, envolvendo inclusive a região do gene Citocromo Oxidase subunidade I (COI) do DNA mitocondrial (DNAmt). Esta região vêm sendo utilizada para auxiliar no estudo de relações filogenéticas, no estudo de diversidade e na identificação de espécies de ácaros tetraniquídeos (Navajas et al., 1994, 1996, 1997 e 1998). O estudo em conjunto dessas duas regiões poderá fornecer maiores subsídios para uma melhor caracterização das populações, como relatado por Navajas et al. (1994) para populações de Mononychellus progressivus Doreste.

Em E. concordis, os 2 polimorfismos simples de nucleotídeos verificados na população de Petrolina, confirmam os resultados obtidos por Navajas et al. (1999) para indivíduos procedentes dessa localidade em relação aos indivíduos de Jaguariúna. A inserção/deleção verificada na população de Petrolina, foi também citada por Navajas et al. (1999). O isolamento reprodutivo verificado para E. concordis no capítulo 5 entre a população de Petrolina e as demais populações, assim como a aparente incompatibilidade reprodutiva parcial entre a população de Jaguariúna e as populações de Viçosa e Pontes e Lacerda podem estar relacionados ainda que indiretamente com os polimorfismos verificados neste estudo. Como citado anteriormente, a condução de estudos envolvendo também a região do gene citocromo oxidade do DNAmt fornecerão mais informações que poderão auxiliar para uma melhor caracterização dessas populações.

Navajas et al. (1998) verificaram maiores diferenças interespecíficas em espécies de Tetranychus nas sequiências do gene COI que no espaçador ITS2, que apresentou baixa divergência de nucleotídeos entre as espécies estudadas. Comparando distintas populações de uma mesma espécie deste grupo (Tetranychus urticae Koch), os 
autores não verificaram qualquer variação naquele espaçador, contrastando com a divergência de nucleotídeos verificada nas seqüências do gene COI. Entretanto, esta diferença de padrão nem sempre é tão marcante; Navajas et al. (1998) encontraram 10 e 12-13 variações nas seqüências de nucleotídeos do espaçador ITS2 e do gene COI, respectivamente, entre 2 populações de Amphitetranychus viennensis Zacher da França e uma população do Japão.

$\mathrm{Na}$ caracterização molecular de populações do himenóptero Trichogramma pretiosum Riley, Ciociola (2000) observou pequenas diferenças em relação a posição de nucleotídeos nas sequiências do espaçador ITS2, que foram entretanto consideradas como variações intra-específicas. Navajas et al. (1999) verificaram completa homologia nos espaçadores ITS 1 e 2 em espécimes de $N$. californicus de áreas geográfica distantes entre si. Entretanto, um baixo nível de polimorfismo nestas regiões foi verificado pelos mesmos autores em espécimes de E. concordis e de E. fallacis, com a substituição de dois nucleotídeos. Navajas et al. (1994) verificaram a incompatibilidade reprodutiva parcial entre populações de $M$. progressivus do Brasil e do Congo. Estas mesmas populações apresentaram também diferenças nas seqüências do espaçador ITS2 e do gene COI. No alinhamento das seqüências do espaçador ITS2, estes autores verificaram um espaço (iserção/deleção) de 4 pares de bases e 2 mutações simples, enquanto 7 mutações foram encontradas no gene COI da população do Brasil em relação à população do Congo. A combinação destes resultados levaram os autores a sugerir que a incompatibilidade reprodutiva observada pudesse estar ligada a diferenças genéticas entre aquelas populações.

Conclui-se que a caracterização molecular, particularmente o seqüenciamento da região do espaçador ITS, pode ser uma importante ferramenta auxiliar e deve ser usada em complemento à técnica de caracterização morfológica e aos estudos biológicos, especialmente em casos que requeiram informações adicionais para a correta identificação de fitoseídeos ao nível de espécie. No estágio atual, mesmo a utilização de outras técnicas de caracterização molecular, parece ter as mesmas limitações, como constatado por Edwards et al. (1997) em estudo de outros grupos de fitoseídeos. Estes autores sugeriram que a caracterização molecular através de RAPD, poderia ser usada 
na separação de espécies crípticas, sendo necessário a confirmação dos resultados através de testes de cruzamentos.

Em uma análise geral dos trabalhos realizados, verifica-se que os resultados da caracterização morfológica indicam a possibilidade de que a população de E. concordis de Petrolina corresponda a uma espécie diferente das demais populações estudadas, mesmo apresentado sobreposição das amplitudes de variação das dimensões de suas estruturas. Desconsiderando-se a possibilidade de transferência de informações genéticas do pai, e levando-se em consideração os resultados obtidos por Congdon \& McMurtry (1986) no cruzamento de duas espécies diferentes de fitoseídeos, poderia se concluir que os resultados dos cruzamentos deste trabalho também indicariam que a população de $E$. concordis de Petrolina pertence a uma espécie diferente das outras populações. Assim como as diferenças observadas na caracterização molecular de cada população e nos resultados obtidos por Navajas et al. (1999), comparando espécies de fitoseídeos distantes entre si, poder-se-ia também concluir que a população de Petrolina pertence a uma espécie diferente. Também a ocorrência dessa espécie em diferentes plantas, com predominância em algumas plantas para determinadas regiões poderia indicar tratar-se de outra espécie. Sugere-se portanto, que outros estudos sejam realizados para se confirmar a que espécie a população de Petrolina pertence. Esses estudos estariam relacionados com estudos de cruzamento envolvendo populações intermediárias entre Petrolina e Viçosa, e com a caracterização molecular da região do gene CO das populações estudadas.

\subsection{Conclusões}

- Através do seqüenciamento dos espaçadores ITS1 e ITS2 é possível discriminar as populações de fitoseídeos identificadas através de caracteres morfológicos como $E$. citrifolius e E. concordis. 
- O seqüenciamento dos espaçadores ITS 1 e 2 , deve ser usado em complemento à técnica de caracterização morfológica e aos estudos biológicos, especialmente em casos que requeiram informações adicionais para a correta identificação de fitoseídeos ao nível de espécie. 


\section{CONCLUSÕES GERAIS}

- As populações de fitoseídeos coletadas em Bauhinia sp., Coffea arabica e Terminalia catappa, e procedentes de Arroio do Meio-RS, Campinas-SP e Petrolina-PE, respectivamente, com base em caracteres morfológicos pertencem à espécie $E$. citrifolius.

- As populações de fitoseídeos coletadas em Passiflora edulis f. flavicarpa, Manihot esculenta, T. catappa, Hevea brasiliensis e C. arabica, procedentes respectivamente de Arroio do Meio, Jaguariúna-SP, Petrolina, Pontes e Lacerda-MT e Viçosa-MG, com base em caracteres morfológicos pertencem à espécie E. concordis.

- A análise de um número muito reduzido de indivíduos identificados como $E$. citrifolius, coletados em Arroio do Meio, Campinas e Petrolina, ou de E. concordis coletados em Arroio do Meio, Jaguariúna, Petrolina, Pontes e Lacerda e Viçosa não permite identificar a espécie ao nível de população, tendo em vista as sobreposições das dimensões das estruturas usadas na identificação de Euseius.

- Os fitoseídeos E. citrifolius e E. concordis se reproduzem através do processo de pseudo-arrenotoquia.

- Em E. citrifolius existe uma incompatibilidade reprodutiva parcial entre a população de Petrolina e as populações de Arroio do Meio e Campinas. 
- As populações identificadas como E. citrifolius procedentes de Arroio do Meio-RS, Campinas-SP e Petrolina-PE pertencem a uma mesma espécie, de vez que o fluxo gênico ocorre entre as populações de Campinas e Arroio do Meio e a população de Petrolina.

- As populações identificadas através de caracteres morfológicos como E. concordis de Arroio do Meio-RS, Jaguariúna-SP, Pontes e Lacerda-MT e Viçosa-MG pertencem a uma mesma espécie com base em testes de cruzamentos.

- Em E. concordis existe fluxo gênico direto entre a população procedente de Arroio do Meio e as populações de Jaguariúna e Pontes e Lacerda, quando estas são colocadas em contato.

- Existe uma aparente incompatibilidade parcial em E. concordis entre as populações de Jaguariúna e Viçosa, e Jaguariúna e Pontes e Lacerda.

- A ocorrência de incompatibilidade reprodutiva em E. concordis entre a população de Petrolina-PE e as demais populações estudadas é caracterizada como do tipo pósacasalamento, e provavelmente não se deva à ação da bactéria simbionte Wolbachia.

- Através do seqüenciamento dos espaçadores ITS1 e ITS2 é possível discriminar as populações de fitoseídeos identificadas através de caracteres morfológicos como $E$. citrifolius e E. concordis.

- O seqüenciamento dos espaçadores ITS 1 e 2, deve ser usado em complemento à técnica de caracterização morfológica e aos estudos biológicos, especialmente em casos que requeiram informações adicionais para a correta identificação de fitoseídeos ao nível de espécie. 
ANEXOS 
Anexo A. Tabela 1. Dimensões (mínimo-máximo) $(\mu \mathrm{m})$ de fêmeas de populações identificadas como Euseius citrifolius procedentes de Arroio do Meio-RS (R), Campinas-SP (S) e Petrolina-PE (P). ( $\mathrm{n}=10$ para cada população).

\begin{tabular}{|c|c|c|c|c|}
\hline $\begin{array}{l}\text { Parâmetros } \\
\text { morfológicos }\end{array}$ & Parátipo $^{2}$ & $\mathrm{R}$ & $S$ & $P$ \\
\hline CED & 312 & $326(317-338)$ & $321(313-327)$ & $304(286-318)$ \\
\hline LED & 230 & $233(221-246)$ & $230(224-240)$ & $220(213-230)$ \\
\hline \multicolumn{5}{|l|}{ Setas dorsais } \\
\hline j1 & 22 & $25(24-27)$ & $27(26-27)$ & $23(20-24)$ \\
\hline j3 & 23 & $25(22-27)$ & $23(22-24)$ & $21(16-24)$ \\
\hline $\mathrm{j} 4$ & 13 & $12(11-14)$ & $11(11-12)$ & $13(11-14)$ \\
\hline j5 & 13 & $12(11-14)$ & $12(11-14)$ & $12(11-12)$ \\
\hline j6 & 13 & $13(11-14)$ & $13(11-14)$ & $14(12-14)$ \\
\hline $\mathrm{J} 2$ & 14 & $14(14-14)$ & $14(14-15)$ & $15(14-16)$ \\
\hline $\mathrm{J} 5$ & 5 & $5(5-7)$ & $5(5-5)$ & $5(4-5)$ \\
\hline $\mathrm{z} 2$ & 18 & $18(16-20)$ & $18(16-19)$ & $16(16-16)$ \\
\hline $\mathrm{z} 4$ & 20 & $19(16-22)$ & $17(16-19)$ & $19(16-23)$ \\
\hline $\mathrm{z} 5$ & 13 & $11(11-12)$ & $12(11-14)$ & $11(11-12)$ \\
\hline $\mathrm{Z1}$ & 13 & $14(12-14)$ & $14(12-14)$ & $14(12-14)$ \\
\hline $\mathrm{Z4}$ & 15 & $16(14-16)$ & $15(14-16)$ & $16(14-16)$ \\
\hline $\mathrm{Z} 5$ & 60 & $66(59-70)$ & $66(62-70)$ & $61(57-68)$ \\
\hline s4 & 31 & $33(30-35)$ & $30(27-32)$ & $31(27-35)$ \\
\hline $\mathrm{S} 2$ & 18 & $18(16-19)$ & $18(16-19)$ & $16(14-16)$ \\
\hline S4 & 18 & $20(16-22)$ & $19(16-19)$ & $18(16-20)$ \\
\hline S5 & 23 & $26(19-30)$ & $25(22-27)$ & $22(20-23)$ \\
\hline r3 & 18 & $18(16-19)$ & $18(16-19)$ & $16(14-18)$ \\
\hline $\mathrm{R} 1$ & 13 & $13(11-14)$ & $13(11-14)$ & $13(11-14)$ \\
\hline \multicolumn{5}{|l|}{ Macrosetas } \\
\hline Genu I & 18 & $16(14-19)$ & $15(14-16)$ & $15(11-18)$ \\
\hline Genu II & 19 & $20(19-22)$ & $20(19-22)$ & $20(19-22)$ \\
\hline Genu III & 23 & $25(19-27)$ & $26(24-28)$ & $23(22-24)$ \\
\hline Tíbia III & 20 & $21(19-22)$ & $22(20-24)$ & $19(18-22)$ \\
\hline Genu IV & 38 & $40(32-43)$ & $41(38-46)$ & $37(31-43)$ \\
\hline Tíbia IV & 28 & $28(27-30)$ & $30(27-32)$ & $28(27-30)$ \\
\hline Tarso IV & 51 & $56(49-62)$ & $55(53-59)$ & $53(43-59)$ \\
\hline ST1 - ST3 & 55 & $55(51-57)$ & $52(51-54)$ & $52(49-54)$ \\
\hline ST2 - ST2 & 65 & $64(62-65)$ & $66(65-68)$ & $63(59-68)$ \\
\hline ST5-ST5 & 72 & $70(68-73)$ & $70(68-73)$ & $67(65-70)$ \\
\hline EVA-ant. & 48 & $54(49-57)$ & $50(46-54)$ & $48(43-51)$ \\
\hline EVA-post. & 72 & $75(73-76)$ & $75(70-76)$ & $67(62-73)$ \\
\hline EVA-comp. & 100 & $102(97-105)$ & $103(97-105)$ & $96(89-103)$ \\
\hline Cálice & 18 & $21(18-24)$ & $21(19-22)$ & $22(20-24)$ \\
\hline Dígito fixo & 22 & $24(22-27)$ & $24(22-24)$ & $24(22-24)$ \\
\hline Dígito móvel & 22 & $23(22-24)$ & $22(22-23)$ & $23(22-24)$ \\
\hline
\end{tabular}

- CED, comprimento do escudo dorsal; LED, largura do escudo dorsal; ST1-ST3, distância entre as setas 1 e 3 do escudo esternal; ST2-ST2, distância entre as setas ST2 do escudo esternal; ST5-ST5, distância entre as setas ST5 do escudo genital; EVA-ant., largura da parte anterior do escudo ventrianal; EVApost., largura da parte posterior do escudo ventrianal; EVA-comp., comprimento do escudo ventrianal.

post., largura da parte posterior do escudo ventrianal; EVA-comp., comprimento do escudo
- Cecilio Baez, Paraguai, 6.I.1969, em Psidium guajava L. (Depositado na ESALQ/USP). 
Anexo A. Tabela 2. Dimensões (mínimo-máximo) $(\mu \mathrm{m})$ de machos de populações identificadas como Euseius citrifolius procedentes de Arroio do Meio-RS (R), Campinas-SP (S) e Petrolina-PE (P). ( $\mathrm{n}=10$ para cada população).

\begin{tabular}{|c|c|c|c|}
\hline $\begin{array}{l}\text { Parâmetros } \\
\text { morfológicos } 1\end{array}$ & $\mathrm{R}$ & $\mathrm{S}$ & $\mathrm{P}$ \\
\hline CED & $242(230-248)$ & $243(235-251)$ & $234(221-240)$ \\
\hline LED & $194(186-202)$ & $183(176-189)$ & $173(159-184)$ \\
\hline \multicolumn{4}{|l|}{ Setas dorsais } \\
\hline j1 & $19(16-22)$ & $20(19-22)$ & $19(18-20)$ \\
\hline j3 & $24(22-27)$ & $25(22-27)$ & $20(19-22)$ \\
\hline $\mathrm{j} 4$ & $12(11-14)$ & $12(11-14)$ & $11(11-14)$ \\
\hline j5 & $11(11-14)$ & $12(11-14)$ & $12(11-14)$ \\
\hline j6 & $12(11-14)$ & $13(11-16)$ & $12(11-14)$ \\
\hline $\mathrm{J} 2$ & $13(11-14)$ & $14(11-14)$ & $13(11-14)$ \\
\hline $\mathrm{J} 5$ & $5(4-5)$ & $5(4-5)$ & $5(4-5)$ \\
\hline $\mathrm{z} 2$ & $19(16-22)$ & $19(16-22)$ & $15(14-16)$ \\
\hline $\mathrm{z} 4$ & $19(16-27)$ & $19(16-22)$ & $16(15-18)$ \\
\hline $\mathrm{z} 5$ & $11(9-14)$ & $13(11-14)$ & $11(11-11)$ \\
\hline $\mathrm{Z} 1$ & $11(9-12)$ & $13(11-14)$ & $13(11-14)$ \\
\hline $\mathrm{Z} 4$ & $14(14-16)$ & $15(12-16)$ & $14(12-15)$ \\
\hline $\mathrm{Z5}$ & $47(40-49)$ & $48(45-51)$ & $44(40-51)$ \\
\hline s4 & $28(24-32)$ & $28(24-32)$ & $24(22-27)$ \\
\hline S2 & $18(16-19)$ & $17(14-19)$ & $15(14-16)$ \\
\hline S4 & $19(16-19)$ & $18(15-20)$ & $17(16-19)$ \\
\hline S5 & $23(19-24)$ & $22(19-26)$ & $19(18-20)$ \\
\hline r3 & $16(16-16)$ & $17(14-19)$ & $14(11-16)$ \\
\hline $\mathrm{R} 1$ & $12(11-14)$ & $12(9-14)$ & $12(11-14)$ \\
\hline \multicolumn{4}{|l|}{ Macrosetas } \\
\hline Genu I & $15(12-18)$ & $11(11-14)$ & $12(11-14)$ \\
\hline Genu II & $16(14-20)$ & $15(14-18)$ & $15(14-16)$ \\
\hline Genu III & $20(19-22)$ & $19(18-19)$ & $17(15-19)$ \\
\hline Tíbia III & $19(19-19)$ & $18(16-19)$ & $16(14-18)$ \\
\hline Genu IV & $28(27-30)$ & $29(27-31)$ & $24(19-27)$ \\
\hline Tíbia IV & $24(22-27)$ & $24(22-27)$ & $21(19-24)$ \\
\hline Tarso IV & $43(40-49)$ & $41(38-46)$ & $41(32-46)$ \\
\hline EVA-ant. & $153(143-189)$ & $145(138-149)$ & $138(124-149)$ \\
\hline EVA-comp. & $94(86-101)$ & $95(90-101)$ & 93 (89 - 97) \\
\hline Espr-comp. & $16(16-16)$ & $15(14-16)$ & $15(14-16)$ \\
\hline
\end{tabular}

T- CED, comprimento do escudo dorsal; LED, largura do escudo dorsal; EVA-ant., largura da parte anterior do escudo ventrianal; EVA-comp., comprimento do escudo ventrianal; Espr-comp., comprimento do espermadáctilo. 
Anexo A. Tabela 3. Dimensões (mínimo-máximo) $(\mu \mathrm{m})$ de fêmeas descendentes de cruzamentos entre populações identificadas como Euseius citrifolius procedentes de Arroio do Meio-RS (R), Campinas-SP (S) e Petrolina-PE (P). ( $\mathrm{n}=10$ para cada combinação).

\begin{tabular}{|c|c|c|c|c|}
\hline \multirow{2}{*}{$\begin{array}{l}\text { Parâmetros } \\
\text { morfológicos }\end{array}$} & \multicolumn{4}{|c|}{ Fêmea x Macho } \\
\hline & PxR & $\mathrm{RxP}$ & PxS & $\mathrm{SxP}$ \\
\hline CED & $286(270-305)$ & $325(313-343)$ & $305(284-319)$ & $317(286-332)$ \\
\hline LED & $216(211-227)$ & $226(219-238)$ & $214(200-224)$ & $221(197-227)$ \\
\hline \multicolumn{5}{|l|}{ Setas dorsais } \\
\hline $\mathrm{j} 1$ & $23(22-24)$ & $24(22-26)$ & $23(22-24)$ & $22(22-24)$ \\
\hline j3 & $19(18-22)$ & $22(22-22)$ & $22(19-24)$ & $21(19-24)$ \\
\hline $\mathrm{j} 4$ & $11(11-14)$ & $11(11-11)$ & $11(11-12)$ & $11(11-11)$ \\
\hline $\mathrm{j} 5$ & $12(11-14)$ & $11(11-12)$ & $12(11-14)$ & $11(11-11)$ \\
\hline j6 & $13(11-14)$ & $12(11-14)$ & $13(11-14)$ & $12(11-14)$ \\
\hline $\mathrm{J} 2$ & $14(12-15)$ & $14(11-16)$ & $13(12-14)$ & $14(12-16)$ \\
\hline J5 & $5(4-5)$ & $5(5-5)$ & $5(4-5)$ & $5(4-5)$ \\
\hline $\mathrm{z} 2$ & $17(15-19)$ & $18(16-19)$ & $17(16-19)$ & $17(16-19)$ \\
\hline $\mathrm{z} 4$ & $17(16-19)$ & $18(16-19)$ & $17(16-19)$ & $17(15-19)$ \\
\hline $\mathrm{z} 5$ & $11(11-11)$ & $11(11-12)$ & $12(11-14)$ & $11(11-11)$ \\
\hline $\mathrm{Z1}$ & $13(11-14)$ & $13(11-14)$ & $13(12-14)$ & $13(11-14)$ \\
\hline $\mathrm{Z4}$ & $16(14-16)$ & $16(14-16)$ & $15(14-16)$ & $15(14-16)$ \\
\hline $\mathrm{Z5}$ & $56(54-58)$ & $61(57-68)$ & $58(53-63)$ & $63(57-68)$ \\
\hline $\mathrm{s} 4$ & $28(19-32)$ & $29(27-30)$ & $30(24-32)$ & $29(27-32)$ \\
\hline $\mathrm{S} 2$ & $16(14-16)$ & $16(16-16)$ & $16(14-18)$ & $16(16-19)$ \\
\hline $\mathrm{S} 4$ & $16(14-19)$ & $19(16-20)$ & $17(16-19)$ & $17(16-19)$ \\
\hline S5 & $21(19-23)$ & $23(19-24)$ & $22(19-26)$ & $22(19-24)$ \\
\hline r3 & $16(14-16)$ & $16(16-18)$ & $17(16-18)$ & $16(14-18)$ \\
\hline $\mathrm{R} 1$ & $13(13-14)$ & $13(11-14)$ & $13(11-14)$ & $12(11-14)$ \\
\hline \multicolumn{5}{|l|}{ Macrosetas } \\
\hline Genu I & $15(14-16)$ & $14(14-15)$ & $15(14-16)$ & $15(14-16)$ \\
\hline Genu II & $19(18-20)$ & $19(19-19)$ & $19(18-20)$ & $20(19-22)$ \\
\hline Genu III & $24(22-26)$ & $24(22-26)$ & $23(22-24)$ & $24(24-27)$ \\
\hline Tíbia III & $19(18-22)$ & $20(19-22)$ & $19(19-20)$ & $19(19-19)$ \\
\hline Genu IV & $37(35-40)$ & $39(38-40)$ & $38(38-40)$ & $40(40-43)$ \\
\hline Tíbia IV & $26(24-27)$ & $26(24-30)$ & $28(24-30)$ & $29(27-32)$ \\
\hline Tarso IV & $54(49-57)$ & $53(51-57)$ & $55(51-59)$ & $57(51-59)$ \\
\hline ST1 - ST3 & $53(51-54)$ & $53(49-57)$ & $53(51-57)$ & $54(51-57)$ \\
\hline $\mathrm{ST} 2-\mathrm{ST} 2$ & $62(59-65)$ & $65(62-68)$ & $65(62-73)$ & $65(62-68)$ \\
\hline ST5-ST5 & $65(59-73)$ & $67(59-73)$ & $64(59-70)$ & $66(62-73)$ \\
\hline EVA-ant. & $51(49-54)$ & $53(46-59)$ & $49(43-51)$ & $50(49-51)$ \\
\hline EVA-post. & $66(62-70)$ & $74(70-84)$ & $69(65-73)$ & $69(62-73)$ \\
\hline EVA-comp. & $91(81-97)$ & $102(96-111)$ & $95(86-103)$ & $99(94-105)$ \\
\hline Cálice & $19(16-22)$ & $19(16-22)$ & $18(16-22)$ & $19(16-22)$ \\
\hline Dígito fixo & $23(22-24)$ & $23(22-24)$ & $23(22-24)$ & $24(22-24)$ \\
\hline Dígito móvel & $22(22-22)$ & $23(22-24)$ & $23(22-24)$ & $23(22-24)$ \\
\hline
\end{tabular}


Anexo A. Tabela 4. Dimensões (mínimo-máximo) $(\mu \mathrm{m})$ de machos descendentes de cruzamentos entre populações identificadas como Euseius citrifolius procedentes de Arroio do Meio-RS (R), Campinas-SP (S) e Petrolina-PE (P). ( $\mathrm{n}=10$ para cada combinação).

\begin{tabular}{|c|c|c|c|c|}
\hline \multirow{2}{*}{$\begin{array}{l}\text { Parâmetros } \\
\text { morfológicos }\end{array}$} & \multicolumn{4}{|c|}{ Fêmea x Macho } \\
\hline & PxR & $\mathrm{RxP}$ & PxS & $\mathrm{SxP}$ \\
\hline CED & $230(219-243)$ & $245(236-270)$ & $240(230-254)$ & $247(238-257)$ \\
\hline LED & $183(167-189)$ & $190(176-200)$ & $190(173-200)$ & $190(181-197)$ \\
\hline \multicolumn{5}{|l|}{ Setas dorsais } \\
\hline j1 & $18(16-19)$ & $21(19-22)$ & $17(14-19)$ & $20(19-22)$ \\
\hline j3 & $20(19-22)$ & $22(19-27)$ & $19(16-22)$ & $23(22-24)$ \\
\hline $\mathrm{j} 4$ & $12(11-14)$ & $11(11-11)$ & $11(9-12)$ & $11(11-14)$ \\
\hline $\mathrm{j} 5$ & $11(11-12)$ & $11(11-15)$ & $11(11-12)$ & $11(11-12)$ \\
\hline j6 & $11(11-14)$ & $12(11-15)$ & $11(11-12)$ & $12(11-14)$ \\
\hline $\mathrm{J} 2$ & $12(11-14)$ & $12(11-14)$ & $11(11-12)$ & $12(11-14)$ \\
\hline J5 & $4(3-5)$ & $5(4-5)$ & $4(3-5)$ & $5(4-5)$ \\
\hline $\mathrm{z} 2$ & $16(14-16)$ & $18(16-19)$ & $15(14-16)$ & $16(16-18)$ \\
\hline $\mathrm{z} 4$ & $16(14-19)$ & $18(16-19)$ & $16(16-16)$ & $18(16-22)$ \\
\hline $\mathrm{z} 5$ & $11(11-14)$ & $11(11-11)$ & $11(9-11)$ & $11(11-11)$ \\
\hline $\mathrm{Z1}$ & $11(11-12)$ & $12(11-14)$ & $11(11-11)$ & $11(11-12)$ \\
\hline $\mathrm{Z4}$ & $14(12-14)$ & $15(14-16)$ & $13(11-14)$ & $14(14-14)$ \\
\hline $\mathrm{Z} 5$ & $40(35-43)$ & $47(42-51)$ & $41(38-43)$ & $44(40-46)$ \\
\hline s4 & $24(19-27)$ & $26(24-27)$ & $23(19-24)$ & $25(24-30)$ \\
\hline $\mathrm{S} 2$ & $14(11-16)$ & $17(16-19)$ & $14(14-16)$ & $15(14-16)$ \\
\hline $\mathrm{S} 4$ & $16(14-19)$ & $20(16-24)$ & $15(14-16)$ & $20(16-24)$ \\
\hline S5 & $19(16-22)$ & $23(19-30)$ & $19(19-22)$ & $23(20-27)$ \\
\hline r3 & $14(14-16)$ & $16(14-16)$ & $14(11-16)$ & $16(14-16)$ \\
\hline $\mathrm{R} 1$ & $11(8-12)$ & $12(11-14)$ & $11(11-12)$ & $11(11-11)$ \\
\hline \multicolumn{5}{|l|}{ Macrosetas } \\
\hline Genu I & $12(11-14)$ & $14(12-16)$ & $16(14-19)$ & $17(16-19)$ \\
\hline Genu II & $14(14-16)$ & $15(14-19)$ & $15(14-16)$ & $16(14-16)$ \\
\hline Genu III & $15(14-16)$ & $18(16-19)$ & $17(16-19)$ & $19(19-19)$ \\
\hline Tíbia III & $16(14-19)$ & $18(16-19)$ & $16(14-16)$ & $19(16-19)$ \\
\hline Genu IV & $25(22-27)$ & $28(27-30)$ & $26(24-27)$ & $28(27-30)$ \\
\hline Tíbia IV & $20(19-22)$ & $22(19-24)$ & $22(22-24)$ & $23(22-27)$ \\
\hline Tarso IV & $38(35-40)$ & $42(39-46)$ & $42(40-46)$ & $41(38-43)$ \\
\hline EVA-ant. & $145(132-154)$ & $151(138-162)$ & $153(144-170)$ & $156(146-167)$ \\
\hline EVA-comp. & $93(89-97)$ & $94(86-108)$ & $94(84-103)$ & $97(81-105)$ \\
\hline Espr-comp. & $16(14-16)$ & $16(16-16)$ & $16(16-16)$ & $16(14-16)$ \\
\hline
\end{tabular}

1. CED, comprimento do escudo dorsal; LED, largura do escudo dorsal; EVA-ant., largura da parte anterior do escudo ventrianal; EVA-comp., comprimento do escudo ventrianal; Espr-comp., comprimento do espermadáctilo. 
Anexo B. Tabela 1. Dimensões (mínimo-máximo) $(\mu \mathrm{m})$ de fêmeas de populações identificadas como Euseius concordis procedentes de Arroio do Meio-RS (R), Jaguariúna-SP (S), Petrolina-PE (P), Pontes e Lacerda-MT (M) e Viçosa-MG (V). (n = 10 para cada população).

\begin{tabular}{|c|c|c|c|c|c|c|}
\hline $\begin{array}{l}\text { Parâmetros } \\
\text { morfológicos } 1\end{array}$ & Holótipo $^{2}$ & $\mathrm{R}$ & $\mathrm{S}$ & $\mathrm{P}$ & $\mathrm{M}$ & $\mathrm{V}$ \\
\hline CED & 317 & $326(313-340)$ & $315(302-332)$ & $307(292-338)$ & $315(292-325)$ & $312(300-321)$ \\
\hline LED & 230 & $233(219-248)$ & $232(224-246)$ & $224(204-246)$ & $227(213-236)$ & $222(211-230)$ \\
\hline \multicolumn{7}{|l|}{ Setas dorsais } \\
\hline j1 & 30 & $28(27-30)$ & $24(22-27)$ & $26(24-32)$ & $27(24-30)$ & $27(27-28)$ \\
\hline j3 & 37 & $36(32-38)$ & $29(27-32)$ & $38(35-43)$ & $37(32-40)$ & $37(35-41)$ \\
\hline j4 & 10 & $8(8-8)$ & $8(7-8)$ & $9(8-11)$ & $8(7-8)$ & $8(8-11)$ \\
\hline j5 & 9 & $8(8-8)$ & $8(7-8)$ & $9(8-11)$ & $8(8-9)$ & $8(7-11)$ \\
\hline j6 & 13 & $11(8-11)$ & $9(8-11)$ & $11(9-14)$ & $9(8-11)$ & $9(8-11)$ \\
\hline $\mathrm{J} 2$ & quebrada & $11(11-11)$ & $10(8-11)$ & $11(9-14)$ & $10(9-11)$ & $9(8-11)$ \\
\hline J5 & quebrada & $5(4-5)$ & $5(4-5)$ & $5(5-5)$ & $5(4-5)$ & $5(5-5)$ \\
\hline $\mathrm{z} 2$ & 17 & $20(16-24)$ & $16(14-19)$ & $23(19-28)$ & $18(14-22)$ & $20(19-22)$ \\
\hline $\mathrm{z} 4$ & 29 & $36(31-38)$ & $28(22-32)$ & $40(35-49)$ & $33(30-38)$ & $34(30-38)$ \\
\hline z5 & 9 & $8(8-8)$ & $8(7-8)$ & $8(7-9)$ & $8(7-9)$ & $8(8-8)$ \\
\hline $\mathrm{Z} 1$ & 11 & $11(9-11)$ & $9(8-11)$ & $11(11-11)$ & $10(8-11)$ & $10(8-11)$ \\
\hline $\mathrm{Z4}$ & 11 & $11(11-11)$ & $11(11-11)$ & $11(11-14)$ & $11(8-11)$ & $11(8-11)$ \\
\hline $\mathrm{Z} 5$ & 64 & $63(59-65)$ & $56(43-62)$ & $61(57-65)$ & $63(59-65)$ & $61(58-62)$ \\
\hline s4 & 52 & $52(49-54)$ & $43(38-49)$ & $55(51-62)$ & $51(49-54)$ & $50(49-54)$ \\
\hline $\mathrm{S} 2$ & 14 & $15(14-16)$ & $14(11-16)$ & $14(12-16)$ & $14(11-14)$ & $14(11-16)$ \\
\hline $\mathrm{S} 4$ & 16 & $17(16-19)$ & $15(14-16)$ & $16(14-19)$ & $16(14-19)$ & $17(14-19)$ \\
\hline S5 & 18 & $20(19-22)$ & $17(16-19)$ & $20(18-23)$ & $17(14-19)$ & $17(14-19)$ \\
\hline r3 & 16 & $17(16-19)$ & $16(14-19)$ & $17(15-19)$ & $16(14-16)$ & $18(16-19)$ \\
\hline $\mathrm{R} 1$ & - & $11(11-11)$ & $10(8-11)$ & $10(9-11)$ & $11(11-11)$ & $12(11-14)$ \\
\hline \multicolumn{7}{|l|}{ Macrosetas } \\
\hline Genu I & - & $24(22-26)$ & $23(22-24)$ & $24(23-27)$ & $24(22-27)$ & $23(21-24)$ \\
\hline Genu II & 24 & $25(24-27)$ & $24(22-24)$ & $25(24-30)$ & $25(24-27)$ & $24(24-27)$ \\
\hline Genu III & 29 & $26(24-27)$ & $27(26-27)$ & $27(24-34)$ & $28(27-30)$ & $28(27-30)$ \\
\hline Tíbia III & - & $21(19-22)$ & $22(22-26)$ & $22(19-27)$ & $23(22-24)$ & $20(19-22)$ \\
\hline Genu IV & 41 & $40(38-43)$ & $37(35-38)$ & $39(34-49)$ & $40(39-43)$ & $41(38-41)$ \\
\hline Tíbia IV & 27 & $28(27-30)$ & $26(24-27)$ & $28(27-35)$ & $30(27-32)$ & $26(24-27)$ \\
\hline Tarso IV & 48 & $49(49-50)$ & $47(46-51)$ & $50(42-57)$ & $48(46-51)$ & $46(43-49)$ \\
\hline ST1 - ST3 & - & $55(54-57)$ & $54(51-54)$ & $54(51-54)$ & $54(51-54)$ & $55(54-58)$ \\
\hline ST2 - ST2 & - & $67(65-70)$ & $63(62-65)$ & $65(60-76)$ & $63(62-65)$ & $67(65-68)$ \\
\hline ST5 - ST5 & - & $69(68-70)$ & $67(59-70)$ & $71(65-78)$ & $68(65-70)$ & $68(65-70)$ \\
\hline EVA-ant. & - & $51(49-54)$ & $47(43-51)$ & $50(46-54)$ & $51(49-54)$ & $49(46-51)$ \\
\hline EVA-post. & - & $71(69-76)$ & $69(65-76)$ & $68(65-73)$ & $70(68-73)$ & $69(68-70)$ \\
\hline EVA-comp. & - & $107(100-113)$ & $108(105-113)$ & $101(93-119)$ & $102(94-105)$ & $97(95-100)$ \\
\hline Cálice & - & $26(24-28)$ & $27(24-30)$ & $25(22-32)$ & $31(27-38)$ & $24(19-27)$ \\
\hline Dígito fixo & - & $24(24-24)$ & $23(20-24)$ & $24(22-24)$ & $24(22-25)$ & $23(22-24)$ \\
\hline Dígito móvel & - & $24(22-24)$ & $22(20-24)$ & $23(22-24)$ & $23(22-24)$ & $22(19-24)$ \\
\hline
\end{tabular}

- CED, comprimento do escudo dorsal; LED, largura do escudo dorsal; ST1-ST3, distância entre as setas 1 e 3 do escudo esternal; ST2-ST2, distância entre as setas ST2 do escudo esternal; ST5-ST5, distância entre as setas ST5 do escudo genital; EVA-ant., largura da parte anterior do escudo ventrianal; EVA-post., largura da parte posterior do escudo ventrianal; EVA-comp., comprimento do escudo ventrianal.

${ }^{2}$ - McMurtry (1983). 
Anexo B. Tabela 2. Dimensões (mínimo-máximo) $(\mu \mathrm{m})$ de machos de populações identificadas como Euseius concordis procedentes de Arroio do Meio-RS (R), Jaguariúna-SP (S), Petrolina-PE (P), Pontes e Lacerda-MT (M) e Viçosa-MG (V). ( $\mathrm{n}=10$ para cada população).

\begin{tabular}{|c|c|c|c|c|c|}
\hline $\begin{array}{l}\text { Parâmetros } \\
\text { morfológicos } 1\end{array}$ & $\mathrm{R}$ & $\mathrm{S}$ & $\mathrm{P}$ & $\mathrm{M}$ & $\mathrm{V}$ \\
\hline CED & $248(239-255)$ & $242(235-248)$ & $233(230-238)$ & $235(216-247)$ & $244(235-254)$ \\
\hline LED & $190(184-197)$ & $190(176-200)$ & $189(181-208)$ & $200(194-205)$ & $187(173-205)$ \\
\hline \multicolumn{6}{|l|}{ Setas dorsais } \\
\hline $\mathrm{j} 1$ & $22(19-24)$ & $21(19-22)$ & $22(22-22)$ & $25(24-27)$ & $20(16-24)$ \\
\hline $\mathrm{j} 3$ & $32(30-34)$ & $28(27-32)$ & $31(27-33)$ & $32(30-32)$ & $30(27-32)$ \\
\hline $\mathrm{j} 4$ & $11(9-14)$ & $9(8-11)$ & $11(9-14)$ & $9(8-11)$ & $8(8-8)$ \\
\hline $\mathrm{j} 5$ & $10(8-11)$ & $9(8-11)$ & $10(8-12)$ & $9(8-11)$ & $8(8-8)$ \\
\hline j6 & $10(8-11)$ & $10(8-11)$ & $11(8-12)$ & $11(9-11)$ & $8(8-11)$ \\
\hline $\mathrm{J} 2$ & $10(8-11)$ & $9(8-11)$ & $10(9-12)$ & $9(8-11)$ & $8(8-8)$ \\
\hline J5 & $5(4-5)$ & $5(4-5)$ & $5(4-5)$ & $4(3-5)$ & $5(4-5)$ \\
\hline $\mathrm{z} 2$ & $23(22-27)$ & $20(19-24)$ & $25(22-27)$ & $20(19-22)$ & $22(20-24)$ \\
\hline $\mathrm{z} 4$ & $31(30-32)$ & $27(22-30)$ & $32(30-36)$ & $31(27-32)$ & $31(27-32)$ \\
\hline $\mathrm{z} 5$ & $10(8-11)$ & $8(8-11)$ & $9(8-11)$ & $8(8-9)$ & $8(7-8)$ \\
\hline $\mathrm{Z1}$ & $9(9-11)$ & $10(8-11)$ & $11(9-11)$ & $11(9-11)$ & $8(8-11)$ \\
\hline $\mathrm{Z4}$ & $11(11-12)$ & $11(9-14)$ & $12(11-16)$ & $12(11-14)$ & $11(11-14)$ \\
\hline $\mathrm{Z5}$ & $50(46-54)$ & $46(40-51)$ & $45(40-49)$ & $48(43-51)$ & $47(46-51)$ \\
\hline s4 & $40(39-43)$ & $35(32-40)$ & $40(35-43)$ & $41(38-43)$ & $37(35-40)$ \\
\hline $\mathrm{S} 2$ & $17(15-19)$ & $15(14-19)$ & $16(14-19)$ & $16(14-18)$ & $17(16-19)$ \\
\hline $\mathrm{S} 4$ & $20(18-22)$ & $17(14-19)$ & $18(14-20)$ & $19(18-19)$ & $19(16-19)$ \\
\hline S5 & $20(19-22)$ & $18(14-22)$ & $19(14-24)$ & $21(19-22)$ & $19(19-22)$ \\
\hline r3 & $17(16-19)$ & $18(14-19)$ & $16(14-19)$ & $16(15-16)$ & $18(16-19)$ \\
\hline $\mathrm{R} 1$ & $11(11-12)$ & $12(9-14)$ & $11(8-14)$ & $12(11-14)$ & $11(11-14)$ \\
\hline \multicolumn{6}{|l|}{ Macrosetas } \\
\hline Genu I & $21(19-22)$ & $19(16-20)$ & $18(16-19)$ & $21(19-22)$ & $19(19-19)$ \\
\hline Genu II & $21(19-22)$ & $20(19-22)$ & $20(18-22)$ & $20(19-22)$ & $19(19-22)$ \\
\hline Genu III & $23(22-25)$ & $22(20-23)$ & $21(19-24)$ & $22(22-24)$ & $20(19-24)$ \\
\hline Tíbia III & $20(19-22)$ & $19(18-22)$ & $19(16-22)$ & $20(19-22)$ & $19(19-22)$ \\
\hline Genu IV & $31(27-35)$ & $30(27-32)$ & $30(27-32)$ & $31(30-32)$ & $28(27-30)$ \\
\hline Tíbia IV & $24(22-27)$ & $22(22-24)$ & $22(19-24)$ & $26(24-27)$ & $23(22-24)$ \\
\hline Tarso IV & $40(36-43)$ & $37(32-40)$ & $39(35-40)$ & $41(39-43)$ & $40(38-43)$ \\
\hline EVA-ant. & $140(135-149)$ & $145(135-157)$ & $137(132-149)$ & $142(135-151)$ & $144(135-149)$ \\
\hline EVA-comp. & $100(94-105)$ & $95(86-108)$ & $92(81$ - 99) & $98(94-103)$ & $93(89-100)$ \\
\hline Espr-comp. & $16(14-19)$ & $15(14-16)$ & $15(14-16)$ & $16(14-16)$ & $16(14-16)$ \\
\hline
\end{tabular}

1. CED, comprimento do escudo dorsal; LED, largura do escudo dorsal; EVA-ant., largura da parte anterior do escudo ventrianal; EVA-comp., comprimento do escudo ventrianal; Espr-comp., comprimento do espermadáctilo. 
Anexo B. Tabela 3. Dimensões (mínimo-máximo) $(\mu \mathrm{m})$ de fêmeas descendentes de cruzamentos entre populações identificadas como Euseius concordis procedentes de Arroio do Meio-RS (R), Jaguariúna-SP (S), Pontes e Lacerda-MT (M) e Viçosa-MG (V). (n=10 para cada combinação).

\begin{tabular}{|c|c|c|c|c|}
\hline \multirow{2}{*}{$\begin{array}{l}\text { Parâmetros } \\
\text { morfológicos }\end{array}$} & \multicolumn{4}{|c|}{ Fêmea x Macho } \\
\hline & $\operatorname{RxS}(n=9)$ & MxR & $\mathrm{RxM}$ & $\mathrm{VxS}$ \\
\hline CED & $327(316-338)$ & $327(317-343)$ & $320(310-332)$ & $328(319-335)$ \\
\hline LED & $243(238-246)$ & $237(230-246)$ & $235(227-248)$ & $239(232-243)$ \\
\hline \multicolumn{5}{|l|}{ Setas dorsais } \\
\hline j1 & $28(27-30)$ & $27(24-28)$ & $26(24-27)$ & $26(24-27)$ \\
\hline j3 & $33(30-35)$ & $32(27-35)$ & $31(30-32)$ & $33(28-35)$ \\
\hline $\mathrm{j} 4$ & $8(8-9)$ & $8(7-8)$ & $8(7-8)$ & $8(8-8)$ \\
\hline j5 & $8(8-9)$ & $8(8-8)$ & $8(8-8)$ & $8(8-11)$ \\
\hline j6 & $10(8-11)$ & $10(8-11)$ & $9(8-11)$ & $9(8-11)$ \\
\hline $\mathrm{J} 2$ & $11(11-11)$ & $10(9-11)$ & $9(8-11)$ & $11(9-11)$ \\
\hline $\mathrm{J} 5$ & $5(4-5)$ & $5(5-5)$ & $5(4-5)$ & $5(5-5)$ \\
\hline $\mathrm{z} 2$ & $18(16-22)$ & $16(14-19)$ & $16(14-19)$ & $18(16-19)$ \\
\hline $\mathrm{z} 4$ & $30(27-32)$ & $28(24-30)$ & $27(24-28)$ & $30(27-35)$ \\
\hline $\mathrm{z} 5$ & $8(7-9)$ & $8(8-8)$ & $8(8-9)$ & $8(8-8)$ \\
\hline $\mathrm{Z1}$ & $11(9-11)$ & $11(9-11)$ & $10(9-11)$ & $11(9-12)$ \\
\hline $\mathrm{Z4}$ & $12(11-14)$ & $11(11-11)$ & $11(9-11)$ & $11(11-12)$ \\
\hline $\mathrm{Z} 5$ & $62(59-68)$ & $61(59-65)$ & $61(59-65)$ & $61(59-65)$ \\
\hline s4 & $48(46-50)$ & $49(46-51)$ & $47(43-54)$ & $47(46-49)$ \\
\hline $\mathrm{S} 2$ & $15(14-16)$ & $13(11-14)$ & $13(11-14)$ & $14(14-16)$ \\
\hline S4 & $17(15-19)$ & $15(12-19)$ & $15(14-16)$ & $17(15-19)$ \\
\hline S5 & $19(16-22)$ & $17(15-19)$ & $16(14-16)$ & $17(16-19)$ \\
\hline r3 & $18(16-19)$ & $16(16-19)$ & $16(14-19)$ & $18(16-19)$ \\
\hline $\mathrm{R} 1$ & $13(11-14)$ & $12(11-14)$ & $11(11-14)$ & $11(11-12)$ \\
\hline \multicolumn{5}{|l|}{ Macrosetas } \\
\hline Genu I & $23(19-24)$ & $24(22-26)$ & $24(24-26)$ & $23(22-24)$ \\
\hline Genu II & $23(22-24)$ & $26(24-27)$ & $25(24-27)$ & $24(24-24)$ \\
\hline Genu III & $25(19-27)$ & $30(28-30)$ & $29(27-30)$ & $27(26-27)$ \\
\hline Tíbia III & $22(22-24)$ & $22(22-24)$ & $22(19-24)$ & $22(19-22)$ \\
\hline Genu IV & $34(30-38)$ & $39(28-43)$ & $40(32-43)$ & $37(30-40)$ \\
\hline Tíbia IV & $28(27-30)$ & $29(28-43)$ & $29(24-30)$ & $27(24-30)$ \\
\hline Tarso IV & $44(40-49)$ & $48(46-49)$ & $48(40-51)$ & $41(39-46)$ \\
\hline ST1 - ST3 & $53(49-55)$ & $54(54-57)$ & $53(49-57)$ & $54(49-57)$ \\
\hline $\mathrm{ST} 2-\mathrm{ST} 2$ & $67(65-69)$ & $66(65-68)$ & $66(65-68)$ & $66(65-68)$ \\
\hline ST5- ST5 & $67(65-70)$ & $71(70-78)$ & $69(68-70)$ & $69(65-70$ \\
\hline EVA-ant. & $48(46-51)$ & $53(49-57)$ & $52(49-54)$ & $48(43-51)$ \\
\hline EVA-post. & $69(65-73)$ & $73(70-76)$ & $72(68-76)$ & $70(62-74)$ \\
\hline EVA-comp. & $109(105-113)$ & $105(100-108)$ & $98(89-105)$ & $101(92-111)$ \\
\hline Cálice & $29(27-32)$ & $27(22-30)$ & $26(19-32)$ & $25(22-27)$ \\
\hline Dígito fixo & $23(22-24)$ & $23(22-24)$ & $23(22-24)$ & $23(22-24)$ \\
\hline Dígito móvel & $23(22-24)$ & $23(22-24)$ & $22(22-23)$ & $22(22-24)$ \\
\hline
\end{tabular}

' - CED, comprimento do escudo dorsal; LED, largura do escudo dorsal; ST1-ST3, distância entre as setas 1 e 3 do escudo esternal; ST2-ST2, distância entre as setas ST2 do escudo esternal; ST5-ST5, distância entre as setas ST5 do escudo genital; EVA-ant., largura da parte anterior do escudo ventrianal; EVA-post., largura da parte posterior do escudo ventrianal; EVA-comp., comprimento do escudo ventrianal. 
Anexo B. Tabela 4. Dimensões (mínimo-máximo) $(\mu \mathrm{m})$ de machos descendentes de cruzamentos entre populações identificadas como Euseius concordis procedentes de Arroio do Meio-RS (R), Jaguariúna-SP (S) e Pontes e Lacerda-MT (M). (n=10 para cada combinação).

\begin{tabular}{|c|c|c|c|c|}
\hline \multirow{2}{*}{$\begin{array}{l}\text { Parâmetros } \\
\text { morfológicos }\end{array}$} & \multicolumn{4}{|c|}{ Fêmea x Macho } \\
\hline & $\mathrm{RxS}$ & SxR & $\mathrm{SxM}$ & $\mathrm{MxS}$ \\
\hline CED & $248(243-254)$ & $249(243-257)$ & $250(239-254)$ & $242(235-251)$ \\
\hline LED & $195(184-202)$ & $185(178-192)$ & $198(192-203)$ & $195(189-202)$ \\
\hline \multicolumn{5}{|l|}{ Setas dorsais } \\
\hline $\mathrm{j} 1$ & $23(22-24)$ & $19(19-20)$ & $22(19-24)$ & $22(22-23)$ \\
\hline j3 & $32(30-34)$ & $29(27-31)$ & $27(24-28)$ & $31(30-32)$ \\
\hline $\mathrm{j} 4$ & $11(8-14)$ & $10(8-11)$ & $10(8-12)$ & $8(8-8)$ \\
\hline $\mathrm{j} 5$ & $10(8-11)$ & $9(8-11)$ & $9(8-11)$ & $8(8-9)$ \\
\hline j6 & $10(8-11)$ & $9(8-11)$ & $10(9-11)$ & $9(8-11)$ \\
\hline $\mathrm{J} 2$ & $10(9-11)$ & $9(8-11)$ & $11(9-11)$ & $8(8-9)$ \\
\hline J5 & $5(4-5)$ & $5(4-5)$ & $5(5-5)$ & $5(4-5)$ \\
\hline $\mathrm{z} 2$ & $23(20-24)$ & $20(16-22)$ & $18(16-20)$ & $22(18-24)$ \\
\hline $\mathrm{z} 4$ & $31(30-32)$ & $28(22-32)$ & $26(22-30)$ & $26(24-30)$ \\
\hline $\mathrm{z} 5$ & $9(8-11)$ & $8(5-9)$ & $9(8-9)$ & $8(8-9)$ \\
\hline $\mathrm{Z} 1$ & $11(9-11)$ & $10(8-11)$ & $12(11-14)$ & $9(8-11)$ \\
\hline $\mathrm{Z4}$ & $12(11-14)$ & $12(11-14)$ & $12(11-14)$ & $11(9-12)$ \\
\hline $\mathrm{Z} 5$ & $46(40-54)$ & $46(43-49)$ & $47(45-49)$ & $46(43-49)$ \\
\hline s4 & $40(38-43)$ & $35(30-38)$ & $34(30-39)$ & $37(35-40)$ \\
\hline $\mathrm{S} 2$ & $16(14-18)$ & $17(16-19)$ & $15(14-19)$ & $14(11-16)$ \\
\hline S4 & $20(19-22)$ & $18(16-20)$ & $18(16-19)$ & $15(11-19)$ \\
\hline S5 & $21(19-22)$ & $19(16-22)$ & $20(19-22)$ & $17(16-19)$ \\
\hline r3 & $18(16-19)$ & $17(14-19)$ & $17(16-19)$ & $15(14-16)$ \\
\hline $\mathrm{R} 1$ & $12(11-14)$ & $10(8-11)$ & $12(11-14)$ & $12(11-14)$ \\
\hline \multicolumn{5}{|l|}{ Macrosetas } \\
\hline Genu I & $20(19-22)$ & $18(16-19)$ & $20(19-22)$ & $20(19-22)$ \\
\hline Genu II & $21(19-23)$ & $19(16-22)$ & $21(19-22)$ & $22(19-24)$ \\
\hline Genu III & $22(20-22)$ & $20(18-22)$ & $23(19-24)$ & $23(22-24)$ \\
\hline Tíbia III & $19(18-20)$ & $19(19-19)$ & $19(18-22)$ & $20(19-22)$ \\
\hline Genu IV & $31(27-34)$ & $28(27-30)$ & $31(30-32)$ & $31(30-32)$ \\
\hline Tíbia IV & $25(22-27)$ & $22(20-24)$ & $26(24-27)$ & $25(23-27)$ \\
\hline Tarso IV & $38(35-40)$ & $38(35-40)$ & $38(35-40)$ & $39(38-42)$ \\
\hline EVA-ant. & $147(140-154)$ & $140(135-143)$ & $151(146-154)$ & $136(104-149)$ \\
\hline EVA-comp. & $98(92-103)$ & $98(92-103)$ & $101(97-103)$ & 93 (89 - 99) \\
\hline Espr-comp. & $15(14-16)$ & $15(14-16)$ & $16(14-19)$ & $18(16-19)$ \\
\hline
\end{tabular}


Anexo B. Tabela 5. Dimensões (mínimo-máximo) $(\mu \mathrm{m})$ de machos descendentes de cruzamentos entre populações identificadas como Euseius concordis procedentes de Pontes e Lacerda-MT (M), Arroio do Meio-RS (R), Jaguariúna-SP (S) e Viçosa-MG (V). (n=10 para cada combinação)

\begin{tabular}{|c|c|c|c|c|}
\hline \multirow{2}{*}{$\begin{array}{l}\text { Parâmetros } \\
\text { morfológicos }\end{array}$} & \multicolumn{4}{|c|}{ Fêmea x Macho } \\
\hline & MxR & $\mathrm{RxM}$ & $\mathrm{SxV}$ & $\mathrm{VxS}$ \\
\hline CED & $238(227-248)$ & $250(240-259)$ & $250(243-259)$ & $243(235-251)$ \\
\hline LED & $177(165-189)$ & $196(184-202)$ & $190(170-202)$ & $183(176-189)$ \\
\hline \multicolumn{5}{|l|}{ Setas dorsais } \\
\hline $\mathrm{j} 1$ & $22(19-24)$ & $22(19-26)$ & $21(19-24)$ & $21(19-24)$ \\
\hline j3 & $30(27-32)$ & $31(27-35)$ & $28(24-31)$ & $31(30-32)$ \\
\hline j4 & $8(8-11)$ & $10(8-11)$ & $9(8-11)$ & $9(8-11)$ \\
\hline j5 & $9(8-11)$ & $9(8-11)$ & $9(8-11)$ & $9(8-11)$ \\
\hline j6 & $10(9-11)$ & $11(8-11)$ & $9(8-11)$ & $10(8-11)$ \\
\hline $\mathrm{J} 2$ & $9(8-11)$ & $11(8-11)$ & $9(8-11)$ & $10(8-11)$ \\
\hline $\mathrm{J} 5$ & $4(4-5)$ & $5(4-5)$ & $5(4-5)$ & $5(4-5)$ \\
\hline $\mathrm{z} 2$ & $19(16-19)$ & $22(19-24)$ & $18(16-19)$ & $21(19-22)$ \\
\hline $\mathrm{z} 4$ & $27(26-30)$ & $29(27-32)$ & $25(23-30)$ & $32(30-40)$ \\
\hline z5 & $8(8-11)$ & $9(8-11)$ & $8(8-9)$ & $8(8-11)$ \\
\hline $\mathrm{Z1}$ & $10(8-11)$ & $11(9-11)$ & $11(9-11)$ & $10(8-11)$ \\
\hline $\mathrm{Z4}$ & $11(9-11)$ & $11(11-12)$ & $11(9-14)$ & $12(11-14)$ \\
\hline $\mathrm{Z} 5$ & $45(38-49)$ & $50(46-54)$ & $45(40-46)$ & $47(43-49)$ \\
\hline s4 & $38(35-40)$ & $37(35-40)$ & $33(30-38)$ & $39(38-40)$ \\
\hline $\mathrm{S} 2$ & $14(14-16)$ & $16(14-19)$ & $15(14-19)$ & $16(14-18)$ \\
\hline S4 & $15(14-16)$ & $17(16-19)$ & $17(14-19)$ & $19(16-20)$ \\
\hline S5 & $16(14-18)$ & $18(16-22)$ & $20(16-22)$ & $19(16-20)$ \\
\hline r3 & $17(16-19)$ & $18(16-19)$ & $17(16-19)$ & $18(16-19)$ \\
\hline $\mathrm{R} 1$ & $14(11-14)$ & $13(11-14)$ & $13(11-16)$ & $12(11-14)$ \\
\hline \multicolumn{5}{|l|}{ Macrosetas } \\
\hline Genu I & $20(19-22)$ & $21(19-22)$ & $19(19-22)$ & $19(18-20)$ \\
\hline Genu II & $20(19-22)$ & $22(20-22)$ & $20(19-22)$ & $20(19-22)$ \\
\hline Genu III & $22(19-24)$ & $23(22-24)$ & $21(19-24)$ & $21(19-23)$ \\
\hline Tíbia III & $20(19-22)$ & $20(19-22)$ & $19(16-19)$ & $19(18-20)$ \\
\hline Genu IV & $31(30-32)$ & $31(30-32)$ & $30(24-32)$ & $30(27-32)$ \\
\hline Tíbia IV & $26(22-30)$ & $26(24-27)$ & $25(24-27)$ & $24(22-24)$ \\
\hline Tarso IV & $40(36-43)$ & $39(38-43)$ & $39(38-40)$ & $38(32-40)$ \\
\hline EVA-ant. & $144(135-149)$ & $146(140-151)$ & $149(143-159)$ & $144(140-149)$ \\
\hline EVA-comp. & $93(86-100)$ & $97(92-103)$ & $98(94-100)$ & $94(90-97)$ \\
\hline Espr-comp. & $17(16-19)$ & $17(16-19)$ & $17(16-19)$ & $16(14-16)$ \\
\hline
\end{tabular}

T- CED, comprimento do escudo dorsal; LED, largura do escudo dorsal; EVA-ant., largura da parte anterior do escudo ventrianal; EVA-comp., comprimento do escudo ventrianal; Espr-comp., comprimento do espermadáctilo. 
Anexo B. Tabela 6. Dimensões (mínimo-máximo) $(\mu \mathrm{m})$ de machos descendentes de cruzamentos entre populações identificadas como Euseius concordis procedentes de Arroio do Meio-RS (R), Petrolina-PE (P), Viçosa-MG (V), Jaguariúna-SP (S) e Pontes e Lacerda-MT (M). (n=10 para cada combinação).

\begin{tabular}{|c|c|c|c|c|}
\hline \multirow{2}{*}{$\begin{array}{l}\text { Parâmetros } \\
\text { morfológicos }\end{array}$} & \multicolumn{4}{|c|}{ Fêmea x Macho } \\
\hline & $\mathrm{RxP}$ & $\mathrm{VxP}$ & $\mathrm{SxP}$ & $\operatorname{MxP} \quad(n=2)$ \\
\hline CED & $250(238-262)$ & $249(243-257)$ & $251(238-259)$ & $238(238-238)$ \\
\hline LED & $207(194-221)$ & $209(197-216)$ & $203(197-208)$ & $193(189-197)$ \\
\hline \multicolumn{5}{|l|}{ Setas dorsais } \\
\hline $\mathrm{j} 1$ & $19(19-20)$ & $20(19-22)$ & $21(19-24)$ & $22(22-22)$ \\
\hline j3 & $29(24-32)$ & $32(32-32)$ & $28(27-30)$ & $30(27-32)$ \\
\hline $\mathrm{j} 4$ & $11(8-14)$ & $9(8-11)$ & $8(8-11)$ & $9(8-9)$ \\
\hline $\mathrm{j} 5$ & $10(8-11)$ & $9(8-11)$ & $8(8-9)$ & $9(8-8)$ \\
\hline j6 & $11(8-12)$ & $10(8-14)$ & $9(8-11)$ & $10(8-11)$ \\
\hline $\mathrm{J} 2$ & $10(9-11)$ & $9(8-11)$ & $8(8-11)$ & $8(8-8)$ \\
\hline J5 & $5(4-5)$ & $5(4-5)$ & $5(3-5)$ & $5(4-5)$ \\
\hline $\mathrm{z} 2$ & $23(20-27)$ & $22(19-24)$ & $17(16-19)$ & $19(19-19)$ \\
\hline $\mathrm{z} 4$ & $29(22-32)$ & $31(30-32)$ & $27(24-27)$ & $30(30-30)$ \\
\hline $\mathrm{z} 5$ & $9(8-11)$ & $8(8-9)$ & $8(5-8)$ & $9(8-9)$ \\
\hline $\mathrm{Z} 1$ & $11(9-11)$ & $10(8-12)$ & $8(8-9)$ & $9(8-9)$ \\
\hline $\mathrm{Z} 4$ & $12(11-14)$ & $12(11-14)$ & $11(8-14)$ & $10(9-11)$ \\
\hline $\mathrm{Z5}$ & $47(43-51)$ & $48(46-51)$ & $45(40-49)$ & $45(43-46)$ \\
\hline s4 & $38(32-43)$ & $38(38-40)$ & $33(30-35)$ & $37(36-38)$ \\
\hline $\mathrm{S} 2$ & $16(14-19)$ & $17(16-19)$ & $15(14-16)$ & $15(14-16)$ \\
\hline $\mathrm{S} 4$ & $20(18-24)$ & $20(19-22)$ & $17(15-22)$ & $17(15-19)$ \\
\hline S5 & $22(19-27)$ & $21(19-22)$ & $19(19-20)$ & $19(18-19)$ \\
\hline r3 & $18(16-19)$ & $18(16-19)$ & $16(14-18)$ & $16(16-16)$ \\
\hline $\mathrm{R} 1$ & $14(12-14)$ & $14(11-14)$ & $12(9-14)$ & $11(11-11)$ \\
\hline \multicolumn{5}{|l|}{ Macrosetas } \\
\hline Genu I & $20(19-22)$ & $20(19-22)$ & $19(18-19)$ & $21(19-22)$ \\
\hline Genu II & $20(19-22)$ & $21(19-22)$ & $19(19-19)$ & $22(22-22)$ \\
\hline Genu III & $23(22-24)$ & $22(22-24)$ & $20(19-22)$ & $23(22-24)$ \\
\hline Tíbia III & $18(16-20)$ & $19(19-19)$ & $19(16-19)$ & $21(19-22)$ \\
\hline Genu IV & $31(28-32)$ & $32(30-35)$ & $30(27-32)$ & $31(30-32)$ \\
\hline Tíbia IV & $25(24-27)$ & $26(24-30)$ & $23(22-27)$ & $24(24-24)$ \\
\hline Tarso IV & $38(35-40)$ & $39(38-40)$ & $37(35-38)$ & $42(40-43)$ \\
\hline EVA-ant. & $147(135-159)$ & $154(140-165)$ & $157(146-176)$ & $151(143-159)$ \\
\hline EVA-comp. & $98(92-103)$ & $95(89-100)$ & $102(92-108)$ & $95(92-97)$ \\
\hline Espr-comp. & $17(16-19)$ & $17(14-19)$ & $17(16-19)$ & $18(16-19)$ \\
\hline
\end{tabular}

1. CED, comprimento do escudo dorsal; LED, largura do escudo dorsal; EVA-ant., largura da parte anterior do escudo ventrianal; EVA-comp., comprimento do escudo ventrianal; Espr-comp., comprimento do espermadáctilo. 


\section{REFERÊNCIAS BIBLIOGRÁFICAS}

ABOU-SETTA, M.M.; CHILDERS, C.C.; DENMARK, H.A.; BROWNING, H.W. Comparative morphology and reproductive compatibility between populations of Euseius mesembrinus (Acari: Phytoseiidae) from Florida and Texas. Experimental and Applied Acarology, v.10, p.213-220, 1991.

ALBERTS, B.; BRAY, D.; JOHNSON, A.; LEWIS, J.; RAFF, M.; ROBERTS, K.; WALTER, T. Essential cell biology: an introduction to the molecular biology of the cell. New York: Garland, 1998. 630p.

AMANO, H.; CHANT, D.A. Mating behaviour and reproductive mechanisms of two species of predacious mites, Phytoseiulus persimilis Athias-Henriot and Amblyseius andersoni (Chant) (Acarina: Phytoseiidae). Acarologia, v.20, p.196-213, 1978.

AMORIM, D.S. Elementos básicos de sistemática filogenética. 2.ed. Ribeirão Preto: Holos; SBE, 1997. 276p.

BAKKER, F.M. Selecting phytoseiid predators for biological control, with emphasis on the significance of tri-trophic interactions. Amsterdam, 1993. 132p. Thesis (Ph.D.) University of Amsterdam.

BELLOTTI, A.C.; SMITH, L.; LAPOINTE, S.L. Recent advances in cassava pest management. Annual Review of Entomology, v.44, p.343-370, 1999. 
BERLOCHER, S.H. Insect molecular systematics. Annual Review of Entomology, v.29, p.403-433, 1984.

BORDENSTEIN, S.R.; O'HARA, F.P.; WERREN, J.H. Wolbachia-induced incompatibility precedes other hybrid incompatibilities in Nasonia. Nature, v.409, p.707-710, 2001.

BREEUWER, J.A.J.; JACOBS, G. Wolbachia: intracellular manipulators of mite reproduction. Experimental and Applied Acarology, v.20, p.421-434, 1996.

BREEUWER, J.A.J.; WERREN, J.H. Microorganisms associated with chromosome destruction and reproductive isolation between two insect species. Nature, v.346, p.558-560, 1990.

CHANT, D.A. Phytoseiid mites (Acarina: Phytoseiidae). Part II. A taxonomic review of the family Phytoseiidae, with descriptions of 38 new species. The Canadian Entomologist, v.12, p.45-166, 1959. Supplement.

CHANT, D.A.; YOSHIDA-SHAUL, E. Adult ventral setal patterns in the family Phytoseiidae (Acari: Gamasida). International Journal of Acarology, v.17, n.3, p.187, 1991.

CIOCIOLA JUNIOR, A.I. Identificação de espécies de Trichogramma (Hymenoptera: Trichogrammatidae) utilizando o seqüênciamento da região ITS2 do rDNA. Piracicaba, 2000. 60p. Tese (Doutorado) - Escola Superior de Agricultura "Luiz de Queiroz”, Universidade de São Paulo.

CONGDON, B.D.; McMURTRY, J.A. Biosystematics of Euseius on California citrus and avocado with the description of a new species (Acari: Phytoseiidae). International Journal of Acarology, v.11, n.1, p.23-30, 1985. 
CONGDON, B.D.; McMURTRY, J.A. The distribution and taxonomic relationships of Euseius quetzali McMurtry in California (Acari: Phytoseiidae). International Journal of Acarology, v.12, n.1, p.7-11, 1986.

CONGDON, B.D.; McMURTRY, J.A. Morphological evidence establishing the loss of paternal chromosomes in males of predatory phytoseiid mites, genus Euseius. Entomologia Experimentalis et Applicata, v.48, p.95-96, 1988.

CROFT, B.A. Comparative studies on four strains of Typhlodromus occidentalis (Acarina: Phytoseiidae). I. Hybridization and reproductive isalation studies. Annals of the Entomological Society of America, v.63, n.6, p.1558-1563, 1970.

DENMARK, H.A.; MUMA, M.H. Some phytoseiid mites of Paraguay (Phytoseiidae: Acarina). Florida Entomologist, v.53, n.4, p.219-227, 1970.

DENMARK, H.A.; MUMA, M.H. Phytoseiid mites of Brazil. Revista Brasileira de Biologia, v.33, n.2, p.235-276, 1973.

EDWARDS, O.R.; MELO, E.L.; SMITH, L.; HOY, M.A. Discrimination of three Typhlodromalus species (Acari: Phytoseiidae) using random amplified polymorphic DNA markers. Experimental and Applied Acarology, v.21, p.101-109, 1997.

EL-BANHAWY, E.M. New Amblyseius mite from Brazil. Revista Brasileira de Biologia, v.35, n.3, p.549-552, 1975.

EL-BANHAWY, E.M. A new predacious mite of the genus Typhlodromus Scheuten from Brazil. Revista Brasileira de Biologia, v.36, n.2, p.531-534, 1976.

EL-BANHAWY, E.M. Description of some unknown phytoseiid mites from Brazil (Mesostigmata: Phytoseiidae). Acarologia, v.20, n.4, p.477-484, 1978 
EL-BANHAWY, E.M. Description of some phytoseiid mites from Brazil (Acarina: Phytoseiidae). Acarologia, v.25, n.2, p.125-144, 1984.

EVANS, J.D. Microsatellite loci in the honey bee parasitc mite Varroa jacobsoni. Molecular Ecology, v.9, p.1433-1449, 2000.

FARAH, S.B. DNA segredos e mistérios. São Paulo: SARVIER, 1997. 276p.

FENTON, B.; MALLOCH, G.; JONES, A.T.; AMRINE JR., J.W.; GORDON, S.C.; A'HARA, S.; McGAVIN, W.J.; BIRCH, N.E. Species identification of Cecidophyopsis mites (Acari: Eriophyidae) from different Ribes species and countries using molecular genetics. Molecular Ecology, v.4, p.383-387, 1995.

FERES, R.J.F. Levantamento e observações naturalísticas da acarofauna (Acari, Arachnida) de seringueiras cultivadas (Hevea spp., Euphorbiaceae) no Brasil. Revista Brasileira de Zoologia, v.17, n.1, p.157-173, 2000.

FERES, R.J.F.; MORAES, G.J. de. Phytoseiid mites (Acari: Phytoseiidae) from woody areas in the State of São Paulo, Brazil. Systematic and Applied Acarology, v.3, p.125-132, 1998.

FERLA, N.J.; MORAES, G.J. de. Ácaros predadores em pomares de maçã no Rio Grande do Sul. Anais da Sociedade Entomológica do Brasil, v.27, n.4, p.649654, 1998.

FERREIRA, M.E.; GRATTAPAGLIA, D. Introdução ao uso de marcadores RAPD e RFLP em análise genética. 3. ed. Brasília: EMBRAPA, CENARGEN, 1998. 220p. (EMBRAPA. CENARGEN. Documento, 20). 
FOUlY, A.H.; ABOU-SETTA, M.M.; CHILDERS, C.C. Effects of diet on the biology and life tables of Typhlodromalus peregrinus (Acari: Phytoseiidae). Environmental Entomology, v.24, n.4, p.870-874, 1995.

FUNGARO, M.H.P. PCR na Micologia. Biotecnologia Ciência \& Desenvolvimento, v.3, n.14, p.12-16, 2000.

FURTADO, I. P. Biossistemática e biologia de espécies de Euseius (Acari: Phytoseiidae) associadas à mandioca. Piracicaba, 1997. 105p. Dissertação (Mestrado) - Escola Superior de Agricultura "Luiz de Queiroz”, Universidade de São Paulo.

GEEST, L.P.S. van der; ELLIOT, S.L.; BREEUWER, J.A.J.; BEERLING, E.A.M. Diseases of mites. Experimental and Applied Acarology, v.24, p.497-560, 2000.

GONDIM JUNIOR, M.G.C.; MORAES, G.J. de. Phytoseiid mites (Acari: Phytoseiidae) associated with palm trees (Arecaceae) in Brazil. Systematic and Applied Acarology, v.6, p.65-94, 2001.

GOTOH, T.; GUTIERREZ, J.; NAVAJAS, M. Molecular comparison of the sibling species Tetranychus pueraricola Ehara et Gotoh and T. urticae Koch (Acari: Tetranychidae). Entomological Science, v.1, n.1, p.55-57, 1998.

GROUT, T.G.; RICHARDS, R.I. The dietary effect of windbreak pollens on longevity and fecundity of a predacious mite Euseius addoensis addoensis (Acari: Phytoseiidae) found in citrus orchards in South Africa. Bulletin of Entomologycal Research, v.82, p.317-320, 1992. 
HAMLEN, R.A. Biological control of spider mites on green house ornamentals using predaceous mites. Proceedings of the Florida State Horticultural Society, v.91, p.247-249, 1978.

HANCE, T.; NEUBERG, P.; NOÈL-LASTELLE, C. The use of fecundity, lobe biometry and the RAPD-PCR technique in order to compare strains of Tetranychus sp. Experimental and Applied Acarology, v.22, p.649-666, 1998.

HOUTEN, Y.M.; RIJN, P.C.J.; TANIGOSHI, L.K.; STRATUM, P.; BRUIN, J. Preselection of predatory mites to improve year-round biological control of western flower thrips in greenhouse crops. Entomologia Experimentalis et Applicata, v.74, p. 225-234, 1995.

HOY, M.A. Parahaploidy of the "arrhenotokous" predator, Metaseiulus occidentalis (Acarina: Phytoseiidae) demonstrated by $\mathrm{x}$-irradiation of males. Entomologia Experimentalis et Applicata, v.26, p.97-104, 1979.

HOY, A.M. Recent advances in genetics and genetic improvement of the phytoseiidae. Annual Review of Entomology, v.30, p.345-370, 1985.

HOY, M.A. Insect molecular genetics. An introduction to principles and applications. San Diego:Academic Press, 1994. 546p.

HOY, A.M.; CAVE, F.E. Premating and postmating isolation among populations of Metaseiulus occidentalis (Nesbitt) (Acarina: Phytoseiidae). Hilgardia, v.56, n.6, p.1-20, 1988.

HOY, C.W.; GLENISTER, C.S. Releasing Amblyseius spp. (Acarina: Phytoseiidae) to control Thrips tabaci (Thysanoptera: Thripidae) on cabbage. Entomophaga, v.36, n.4, p.561-573, 1991. 
HOY, M.A.; KNOP, N.F. Selection for and genetic analysis of permethrin resistance in Metaseiulus occidentalis: Genetic improvement of a biological control agent. Entomologia Experimentalis et Applicata , v.30, p.10-18, 1981.

HOYING, S.A.; CROFT, B.A. Comparisons between populations of Typhlodromus longipilus Nesbitt and T. occidentalis Nesbitt: Taxonomy, distribution, and hybridization. Annals of the Entomological Society of America, v.70, n.1, p.150159, 1977.

INTERNATIONAL INSTITUTE OF TROPICAL AGRICULTURE. Ecologically sustainable cassava plant protection. Benin, 1995. 85p. (Annual Report).

JOHANOWICZ, D.L.; HOY, M.A. Wolbachia in a predator-prey system: 16S ribosomal DNA analysis of two Phytoseiids (Acari: Phytoseiidae) and their prey (Acari: Tetranychidae). Annals of the Entomological Society of America, v.89, n.3, p. 435-441, 1996.

JONES, S.A.; MORSE, J.G. Use of isoelectric focusing eletrophoresis to evaluate citrus thrips (Thysanoptera: Thripidae) predation by Euseius tularensis (Acari: Phytoseiidae). Environmental Entomology, v.24, n.5, p.1040-1051, 1995.

KOSTIAINEN, T.S.; HOY, M.A. The Phytoseiidae as biological control agents of pest mites and insects: a bibliography. Gainesville: University of Florida, 1996. $355 \mathrm{p}$.

LANZA, M.A.; GUIMARÃES, C.T.; SCHUSTER, I. Aplicação de marcadores moleculares no melhoramento genético. Informe Agropecuário, v.21, n.204, p.97$108,2000$. 
LOFEGO, A.C. Caracterização morfológica e distribuição geográfica das espécies de Amblyseiinae (Acari: Phytoseiidae) no Brasil. São Paulo, 1998. 167p. Dissertação (M.S.) - Instituto de Biociências, Universidade de São Paulo.

MARSHALL. D.B.; THISTLEWOOD, H.M.A.; LESTER, P.J. Release, establishment, and movement of the predator Typhlodromus pyri (Acari: Phytoseiidae) on apple. The Canadian Entomologist, v.133, p.279-292, 2001.

MAYR, E. Populações, espécies e evolução. Trad. de H. Reichardt. São Paulo: Ed. Nacional; EDUSP, 1977. 485p.

McMURTRY, J.A. Some predaceous mites (Phytoseiidae) on citrus in the Medetiterranean region. Entomophaga, v.22, p.19-30, 1977.

McMURTRY, J.A. Biosystematics of three taxa in the Amblyseius finlandicus group from South Africa, with comparative life history studies (Acari: Phytoseiidae). International Journal of Acarology, v.6, n.2, p.147-156, 1980.

McMURTRY, J.A. The use of phytoseiids for biological control: Progress and future prospects. In: HOY, M. A. (Ed.) Recent advances in knowledge of the Phytoseiidae. Berkeley: University of California, 1982. cap.2, p.23-48.

McMURTRY, J.A. Phytoseiid mites from Guatemala, with descriptions of two new species and redefinitions of the genera Euseius, Typhloseiopsis, and the Typhlodromus occidentalis species-group (Acari: Mesostigmata). International Journal of Entomology, v.25, n.4, p.249-272, 1983.

McMURTRY, J.A. Dynamics and potential impact of 'generalist' phytoseiids in agroecosystems and possibilities for establishment of exotic species. Experimental and Applied Acarology, v.14, p.371-382, 1992. 
McMURTRY, J.A.; CROFT, B.A. Life-styles of phytoseiid mites and their roles in biological control. Annual Review of Entomology, v.42, p.291-321, 1997.

McMURTRY, J.A.; MORAES, G.J. de. Some phytoseiid mites from Peru with descriptions of four new species (Acari: Phytoseiidae). International Journal of Acarology, v.15, n.3, p.179-188, 1989.

McMURTRY, J.A.; SCRIVEN, G.T. Insectary productions of phytoseiid mites. Journal of Economic Entomology, v.58, n.2, p.282-284, 1965.

McMURTRY, J.A.; HUFFAKER, C.B.; VRIE, M. van de. Ecology of tetranychid mites and their natural enemies: a review. I. Tetranychid enemies: their biological characters and the impact of spray practices. Hilgardia, v.40, n.11, p.331-390, 1970.

McMURTRY, J.A.; MAHR, D.L.; JOHNSON, H.G. Geographic races in the predaceous mite, Amblyseius potentillae (Acari: Phytoseiidae). International Journal of Acarology, v.2, n.1, p.23-28, 1976.

McMURTRY, J.A.; OATMAN, E.R.; PHILLIPS, P.A.; WOOD, C.W. Establishment of Phytoseiulus persimilis (Acari: Phytoseiidae) in southern California. Entomophaga, v.23, n.2, p.175-179, 1978.

MESA, N.C.; BRAUN, A.R.; BELlOTTI, A.C. Comparison of Mononychellus progresivus and Tetranychus urticae as prey for five species of phytoseiid mites. Experimental and Applied Acarology, v.9, p. 159-168, 1990. 
MEYERDIRK, D.E.; COUDRIET, D.L. Predation and developmental studies of Euseius hibisci (Chant) (Acarina: Phytoseiidae) feeding on Bemisia tabaci (Gennadius) (Homoptera: Aleyrodidae). Environmental Entomology, v.14, p.2427, 1985.

MORAES, G.J. de. Importance of taxonomy in biological control. Insect Science and its Applications, v.8, n.4/6, p.841-844, 1987.

MORAES, G.J. de. Controle biológico de ácaros fitófagos. Informe Agropecuário, v.15, n.167, p.55-62, 1991.

MORAES, G.J. de; LIMA, H.C. Biology of Euseius concordis (Chant) (Acarina: Phytoseiidae) a predator of the tomato russet mite. Acarologia, v.24, n.3, p.251$255,1983$.

MORAES, G.J. de.; McMURTRY, J.A. Biology of Amblyseius citrifolius (Denmark and Muma) (Acarina - Phytoseiidae). Hilgardia, v.49, n.1, p.1-29, 1981.

MORAES, G.J. de.; McMURTRY, J.A. Phytoseiid mites (Acarina) of northeastern Brazil with descriptions of four new species. International Journal of Acarology, v.9, n.3, p.131-148, 1983.

MORAES, G.J. de.; McMURTRY, J.A.; DENMARK, H.A. A catalog of the mite family Phytoseiidae: references to taxonomy, synonymy, distribution and habitat. Brasília: EMBRAPA-DDT, 1986. 353p.

MORAES, G.J. de.; MELO, E.L.; GONDIM Jr., M.G.C. Description of a new species of phytoseiid mite from northeastern Brazil and redescription of Neoseiulus gracilis (Acari: Phytoseiidae). Florida Entomologist, v.80, n.3, p.319-324, 1997. 
MORAES, G.J. de.; MESA, N.C.; BRAUN, A. Some phytoseiid mites of Latin America (Acari: Phytoseiidae). International Journal of Acarology, v.17, n.2, p.117-139, 1991.

MORAES, G.J. de.; ALENCAR, J.A.; LIMA, J.L.S.; YANINEK, J.S.; DELALIBERA JR., I. Alternative plant habitats for common phytoseiid predators of the cassava green mite (Acari: Phytoseiidae, Tetranychidae) in Northeast Brazil. Experimental and Applied Acarology, v.17, n.1/2, p.77-90, 1993.

MOREIRA, P.H.R. Ocorrência, dinâmica populacional de ácaros predadores em citros e biologia de Euseius citrifolius (Acari: Phytoseiidae). Jaboticabal, 1993. 125p. Dissertação (M.S.) - Faculdade de Ciências Agrárias e Veterinárias de Jaboticabal, Universidade Estadual Paulista "Júlio de Mesquita Filho".

NAVAJAS, M.; FENTON, B. The application of molecular markers in the study of diversity in acarology: a review. Experimental and Applied Acarology, v.24, p.751-774, 2000.

NAVAJAS, M.; GUTIERREZ, J.; GOTOH, T. Convergence of molecular and morphological data reveals phylogenetic information on Tetranychus species and allows the restoration of the genus Amphitetranychus (Acari: Tetranychidae). Bulletin of Entomological Research, v.87, p.283-288, 1997.

NAVAJAS, M.; GUTIERREZ, J.; LAGNEL, J. Mitochondrial cytochrome oxidase I in tetranychid mites: a comparison between molecular phylogeny and changes of morphological and life history traits. Bulletin of Entomological Research, v.86, p.407-417, 1996. 
NAVAJAS, M.; COTTON, D.; KREITER, S.; GUTIERREZ, J. Molecular approach in spider mites (Acari: Tetranychidae): preliminary data on ribosomal DNA sequences. Experimental and Applied Acarology, v.15, p.211-218, 1992.

NAVAJAS, M.; LAGNEL, J.; FAUVEL, G.; MORAES, G.de. Sequence variation of ribosomal internal transcribed spacers (ITS) in commercially important Phytoseiidae mites. Experimental and Applied Acarology, v.23, p.851-859, 1999.

NAVAJAS, M.; LAGNEL, J.; GUTIERREZ, J.; BOURSOT, P. Species-wide homogeneity of nuclear ribosomal ITS2 sequences in the spider mite Tetranychus urticae contrasts with extensive mitochondrial COI polymorphism. Heredity, v.80, p.742-752, 1998.

NAVAJAS, M.J.; THISTLEWOOD, H.M.A.; LAGNEL, J.; HUGHES, C. Microsatellite sequences are under-represented in two mite genomes. Insect Molecular Biology, v.7, n.3, p.249-256, 1998a.

NAVAJAS, M.; GUTIERREZ, J.; BONATO, O.; BOLLAND, H.R.; MAPANGOUDIVASSA, S. Intraspecific diversity of the cassava green mite Mononychellus progressivus (Acari: Tetranychidae) using comparisons of mitochondrial and nuclear ribosomal DNA sequences and cross-breeding. Experimental and Applied Acarology, v.18, p.351-360, 1994.

NORONHA, A.C.S.; MESA, N.C. Efeito de diferentes alimentos sobre a fecundidade de Amblyseius limonicus (Acarina: Phytoseiidae). Revista Brasileira de Mandioca, v.9, n.1/2, p.75-81, 1990. 
ODUOR, G.I. The effect of cassava (Manihot esculenta Crantz) leaf exudate on the life history and behaviour of the predacious mite Typhlodromalus limonicus (Garman \& McGregor) (Acari: Phytoseiidae). Amsterdam: University of Amsterdam, 1988. 14p. (Report - M.Sc. Thesis).

O'NEILL, S.L.; KARR, T.L. Bidirectional incompatibility between conspecific populations of Drosophila simulans. Nature, v.348, p.178-180, 1990.

OSAKABE, M.; KOMAZAKI, S. Differences in esterase isozymes between Panonychus citri population infesting citrus and Osmanthus. Experimental and Applied Acarology, v.20, p.113-119, 1996.

PALLINI FILHO, A.; MORAES, G.J. de.; BUENO, V.H.P. Ácaros associados ao cafeeiro (Coffea arabica L.) no Sul de Minas Gerais. Ciência e Prática, v.16, n.3, p.303-307, 1992.

PEÑA, J.E.; OSBORNE, L. Biological control of Polyphagotarsonemus latus (Acarina: Tarsonemidae) in greenhouses and field trials using introductions of predacious mites (Acarina: Phytoseiidae). Entomophaga, v.41, n.2, p.279-285, 1996.

PERROT-MINNOT, M.J.; NAVAJAS, M. Biparental inheritance of RAPD markers in males of the pseudo-arrhenotokous mite Typhlodromus pyri. Genome, v.38, p.838844, 1995.

PERROT-MINNOT, M.J.; LAGNEL, J.; MIGEON, A.; NAVAJAS, M. Tracking paternal genes with DALP markers in a pseudoarrhenotokous reproductive system: biparental transmission but haplodiploid-like inheritance in the mite Neoseiulus californicus. Heredity, v.84, p.702-709, 2000. 
PICKETT, C.H.; GILSTRAP, F.E. Inoculative release of phytoseiids (Acari) for the biological control of spider mites (Acari: Tetranychidae) in corn. Environmental Entomology, v.15, p.790-794, 1986.

PINTO, L.R.; VIEIRA, M.L.C.; SOUZA, A.P.; SOUZA JUNIOR, C.L. Isoenzimas e microssatélites em plantas. Biotecnologia Ciência \& Desenvolvimento, v.4, n.20, p.16-19, 2001.

RASMY, A.H.; ELLAITHY, A.Y. Introduction of Phytoseiulus persimilis for twospotted spider mite control in greenhouses in Egypt (Acari: Phytoseiidae, Tetranychidae). Entomophaga, v.33, n.4, p.435-438, 1988.

ROWELL, H.J.; CHANT, D.A.; HANSELL, I.C. The determination of setal homologies and setal patterns on the dorsal shield in the family Phytoseiidae (Acarina: Mesostigmata). Canadian Entomologist, v.110, p.859-876, 1978.

SABELIS, M.W. Sex allocation. In: HELLE, W.; SABELIS, M.W. (Ed.) Spider mites their biology, natural enemies and control. Amsterdam: Elsevier, 1985. v.1B, cap. 2.1., p.83-94.

SABELIS, M.W.; NAGELKERKE, C.J. Evolution of pseudo-arrhenotoky. Experimental and Applied Acarology, v.4, p.301-318, 1988.

SATO, M.E.; RAGA, A.; CERÁVOLO, L.C.; ROSSI, A.C.; POTENZA, M.R. Ácaros predadores em pomar cítrico de Presidente Prudente, Estado de São Paulo. Anais da Sociedade Entomológica do Brasil, v.23, n.3, p.435-441, 1994.

SCHULTEN, G.G.M. Mating. In: HELLE, W.; SABELIS, M.W. (Ed.) Spider mites their biology, natural enemies and control. Amsterdam: Elsevier, 1985. v.1B, cap. 2.1., p.55-65. 
SILVA, I.M.M.S.; HONDA, J.; KAN, F. van; HU, J.; NETO, L.; PINTUREAU, B.; STOUTHAMER, R. Molecular differentiation of five Trichogramma species occurring in Portugal. Biological Control, v.16, p.177-184, 1999.

TAKAHASHI, F.; CHANT, D.A. Phylogenetic relationships in the genus Phytoseiulus Evans (Acari: Phytoseiidae). IV. Reproductive isolation. International Journal of Acarology, v.19, n.4, p.305-311, 1993.

TORRES, R.A.; GANAL, M.; HEMLEBEN, V. GC balance in the internal transcribed spacers ITS 1 and ITS 2 of nuclear ribosonal RNA genes. Journal of Molecular Evolution, v.30, p.170-181, 1990.

TSAGKARAKOU, A.; NAVAJAS, M.; LAGNEL, J.; PASTEUR, N. Population structure in the spider mite Tetranychus urticae (Acari: Tetranychidae) from Crete based on multiple allozymes. Heredity, v.78, p.84-92, 1997.

TSAGKARAKOU, A.; NAVAJAS, M.; PAPAIOANNOU-SOULIOTIS, P.; PASTEUR, N. Gene flow among Tetranychus urticae (Acari: Tetranychidae) populations in Greece. Molecular Ecology, v.7, p.71-79, 1998.

TSAGKARAKOU, A.; NAVAJAS, M.; LAGNEL, J.; GUTIERREZ, J.; PASTEUR, N. Genetic variability in Tetranychus urticae (Acari: Tetranychidae) from Greece: Insecticide resistance and isozymes. Journal of Economic Entomology, v.86, n.6, p.1354-1358, 1996.

ZACARIAS, M.S. Diversidade de ácaros (Arthropoda: Acari) em euforbiáceas (Euphorbiaceae) em três localidades do Estado de São Paulo. Piracicaba, 2001. 154p. Tese (Doutorado) - Escola Superior de Agricultura "Luiz de Queiroz", Universidade de São Paulo. 
WARD, P.S.; BOUSSY, I.A.; SWINCER, D.E. Electrophoretic detection of enzyme polymorphism and differentiation in three species of spider mites (Tetranychus) (Acari: Tetranychidae). Annals of the Entomological Society of America, v.75, p. 595-598, 1982.

WERREN, J.H. Biology of Wolbachia. Annual Review of Entomology, v.42, p.587609, 1997.

WESSON, D.M.; McLAIN, D.K.; OLIVIER, J.H.; PIESMAN, J.; COLLINS, F.H. Investigation of the validity of species states of Ixodes dammini (Acari: Ixodidae) using rDNA. Proceedings National Academy of Sciences USA, v.90, p.1022110225, 1993.

WYSOKI, M.; McMURTRY, J.A. Karyotypes of eight species of phytoseiid mites of the genus Amblyseius Berlese (Acarina: Mesostigmata). Genetica, v.47, n.3, p.237239, 1977.

YLI-MATTILA, T.; PAAVANEN-HUHTALA, S.; FENTON, B.; TUOVINEN, T. Species and strain identification of the predatory mite Euseius finlandicus by RAPD-PCR and ITS sequences. Experimental and Applied Acarology, v.24, p.863-880, 2000.

YUE, B.; TSAI, J.H. Development, survivorship, and reproduction of Amblyseius largoensis (Acari: Phytoseiidae) on selected plant pollens and temperatures. Environmental Entomology, v.25, n.2, p.488-494, 1996. 